IZA DP No. 4224

Transition Fatigue?

Cross-Country Evidence from Micro Data

Riccardo Rovelli

Anzelika Zaiceva

June 2009 


\title{
Transition Fatigue? Cross-Country Evidence from Micro Data
}

\author{
Riccardo Rovelli \\ University of Bologna, \\ DARRT and IZA
}

Anzelika Zaiceva

University of Bologna,

DARRT and IZA

\section{Discussion Paper No. 4224 \\ June 2009}

IZA

P.O. Box 7240

53072 Bonn

Germany

Phone: +49-228-3894-0

Fax: +49-228-3894-180

E-mail: iza@iza.org

\begin{abstract}
Any opinions expressed here are those of the author(s) and not those of IZA. Research published in this series may include views on policy, but the institute itself takes no institutional policy positions.

The Institute for the Study of Labor (IZA) in Bonn is a local and virtual international research center and a place of communication between science, politics and business. IZA is an independent nonprofit organization supported by Deutsche Post Foundation. The center is associated with the University of Bonn and offers a stimulating research environment through its international network, workshops and conferences, data service, project support, research visits and doctoral program. IZA engages in (i) original and internationally competitive research in all fields of labor economics, (ii) development of policy concepts, and (iii) dissemination of research results and concepts to the interested public.
\end{abstract}

IZA Discussion Papers often represent preliminary work and are circulated to encourage discussion. Citation of such a paper should account for its provisional character. A revised version may be available directly from the author. 


\section{ABSTRACT \\ Transition Fatigue? Cross-Country Evidence from Micro Data*}

The transition process has had different distributional impacts across different interest groups and countries. These have led to differences in the support for transition. In this paper, we study support attitudes for both the economic and political transition using data from the New Barometer Surveys for 14 transition economies from 1991 to 2004. We document that the overall support is low and heterogeneous across countries and individuals. Support attitudes are lower among the old, less skilled, unemployed, poor, and those living in the CIS countries. There seems to be an increasing trend in the support for the economic transition in most countries. Our findings are robust to changes in the definition and measurement of the dependent variable. We also find evidence that transition-related hardship, opinions on the speed of reforms, political preferences and preferences towards redistribution, ideology and social capital matter. Finally, we show that individual preferences for secure jobs, the role of state and trust in politicians as well as better institutions, in particular, the quality of governance, seem to contribute mostly to explaining the lower levels of the support in the CIS countries.

JEL Classification: $\quad$ O57, A13, P26, P36

Keywords: political economy, transition, subjective attitudes

Corresponding author:

Riccardo Rovelli

University of Bologna

Strada Maggiore 45

40125 Bologna

Italy

E-mail: riccardo.rovelli@unibo.it

\footnotetext{
* We acknowledge use of data from the New Europe Barometer, New Russia Barometer and New Baltic Barometer surveys, as detailed in the Data Appendix. We are grateful to IZA for making several surveys available to us and to Fondazione Cassa dei Risparmi di Forlì and the Volkswagen-Stiftung for financial support. We thank Tito Boeri, Irina Denisova, John Earle, Andrea Ichino, Hartmut Lehmann, Chiara Monfardini, Richard Rose, Claudia Senik, Zahra Siddique, Jonathan Wadsworth and seminar participants at the University of Bologna, Bocconi University, and participants at the Moscow Higher School of Economics, CIDE and IZA/World Bank conferences for helpful comments and suggestions.
} 


\section{Introduction}

In the last two decades former socialist countries went through the unprecedented experience of a parallel transition to a market economy and to democracy. The implementation of political and economic reforms began in the early 1990s in most countries in Central and Eastern Europe (CEE) and in the Commonwealth of Independent States (CIS). However, the paths of reform implementation and the sequence of the reforms differed across countries - a difference which is sometimes exemplified in the distinction between a so-called "big-bang" approach and "gradualism". ${ }^{1}$

The transition process has been characterized almost everywhere by an initial deep recession, which in many countries also involved widespread unemployment. However, the pattern, depth and duration of this transitional recession and the speed of the subsequent recovery differed considerably across countries with CEE countries, on average, recovering faster. ${ }^{2}$ A common feature to all the transition economies was the need to refocus the orientation of international trade, to restructure internal production, and to reallocate labor across regions, sectors and firms (Campos and Coricelli, 2002). Privatization, trade liberalization, macroeconomic stabilization and economic restructuring took place in a situation of institutional change, where many institutions that had hitherto provided social protection collapsed and others, such as taxation or banking, had to be introduced practically ex novo. The initial stages of transition brought about remarkable increases in income inequality in all countries, including those that had managed to avoid large increases in unemployment rates (Milanovic and Ersado, 2008).

One of the most important criteria for assessing the success of transition is a country's achievement in reallocating labor (Boeri and Terrell, 2002). As transition generated an unprecedented economic insecurity, job insecurity became a crucial issue for many (Linz and Semykina, 2008). Low-educated, young, single individuals and women, especially married women, were more likely to become unemployed (Boeri and Terrell, 2002). Thus, transitional reforms soon produced both economic "winners" and "losers" (Brainerd, 1998; Terrell, 1999), and for those who were less ready or able to face these changes, the costs of transition may well have outweighed, at least for some time, its benefits.

The adjustment patterns of the output and labor markets differed substantially between the CEE and CIS countries. With a few exceptions, all Central and Eastern European countries experienced a U-shaped pattern of GDP, a large fall in employment early in the 1990s and some decline in labor productivity leading to rapid structural change but also to high unemployment (with the exception of the Czech Republic), much of which was long-term. In contrast, the CIS countries typically faced a L-shaped pattern of GDP during the 1990s, relatively little decline in employment and a relatively small reallocation of labor. Here, however, there was a more pronounced deterioration in labor productivity and of real wages, as well as a significantly larger increase in inequality than in the CEE countries (Boeri and Terrell, 2002;

\footnotetext{
${ }^{1}$ Although a simplification and generalization, these definitions are useful for a general description of the transition process. See, for example, Roland (2002) for a comprehensive discussion of the political economy of transition and a survey of studies on economic policy reform. Note that countries differed also in the initial conditions, a fact that must be taken into account when modeling the outcomes of transition.

${ }^{2}$ In fact, the relative output performance of transition countries has been the subject of much debate in the literature. Among the potential explanations of the diversity of outcomes are geographical factors (such as proximity to the EU), history (such as the length of time under Soviet rule or the degree of pre-socialism development of capitalist informal institutions) as well as the different paths and sequences of reforms.
} 
Svejnar, 2002). ${ }^{3}$ Overall, while the labor market adjustment process took the form of larger declines in employment in the CEE countries, it typically occurred through real wage declines in the CIS. And only as transition progressed, unemployment began to increase gradually also in the CIS countries (Svejnar, 2002).

The speed with which an economy restructures and destroys the old state sector jobs is a subject of large literature on the optimal speed of transition (see, for example, Boeri, 2000 for a review, and footnote 7). However, by focusing on speed and thus distinguishing between the "big bang" vs. "gradualism" approaches, this literature fails to explain the key differences in the adjustment processes in the CEEC and CIS (Boeri and Terrell, 2002). Alternative explanations relate the differences in performance to differences in institutions. In particular, social safety nets and non-employment benefits may have prevented the decline of wages in central and eastern Europe by setting floors to them (Boeri and Terrell, 2002). In addition, in the CIS weaker legal systems and weaker enforcement of laws and regulations supported a profound lack of transparency and uncertain corporate governance, which in turn facilitated the spreading of corruption and rent-seeking behavior (Svejnar, 2002; Roland, 2002). In general, the existing literature stresses the need to take a political economy perspective in order to explain why different policy models were adopted by different countries. Moreover, it is desirable to incorporate noneconomic institutions into the analysis, such as governance, democracy, social norms and values, as well as the quality of laws and regulations (Roland, 2002). Our paper addresses these challenges. By focusing on individual attitudes towards transition, relating them to individual experiences and suggesting several potential explanations of the differences in these attitudes between the CIS and CEE countries, we provide evidence on the link between the outcomes of transition and the formation of support for it in a political economy framework.

The recent performance of the transition countries has been characterized, at least until the recession of 2008-2009, by strong economic growth and, for the new EU member states, by a decline in unemployment and convergence towards the EU institutions. Average economic growth has been accelerating in nearly all transition countries, averaging 5.9 percent in 2000 - 2007, up from only 1.1 percent in 1995-1999. ${ }^{4}$ On the other hand, the pace of reforms in 2007 was the slowest since the transition began (EBRD, 2007a). And, in a stark contrast with improving living standards, the recent EBRD Transition Report documents that there is a widespread dissatisfaction with the outcomes of transition (EBRD, 2007a). In 2007, 49 percent of respondents disagreed (and only 35 percent agreed) with the statement that the economic situation in their country today is better than around 1989, with similar numbers corresponding to the political situation (EBRD, 2007a; see also Guriev and Zhuravskaya, 2009). Countries with the largest proportion of citizens dissatisfied with the economic situation were Hungary (75 percent), Ukraine (70 percent), Kyrgyzstan (70 percent), Bulgaria (63 percent) and Moldova (61 percent) (ibid.). And also privatization, one of the most important transition reforms, receives low support, with over 80 percent of respondents willing to revise it (EBRD, 2007a; Denisova et al., 2007).

It is not easy to disentangle whether this is due to a "fatigue for some countries following accession to the European Union, uncertainties over the chances of EU membership for those in the "waiting room" or

\footnotetext{
3 The high employment rates in some countries, such as Russia, could also reflect the movement of workers from stable full-time jobs to more insecure temporary or part-time jobs in the formal or informal sector (Linz and Semykina, 2008).

${ }^{4}$ EBRD (2007a). Data refer to 29 countries, 2006 and 2007 are estimated.
} 
complacency brought on by the large oil and gas windfall" (EBRD, 2007a, p. vi). In general, it seems that there is a certain "transition fatigue" in the region, a discontent with the process of transition that could also be held responsible for the frequent changes of government in several countries in the recent years. Individual opinions and attitudes matter, and it is also likely that the ongoing economic and financial turmoil will further reinforce these negative feelings, as several countries in the region already face political instability and the Czech Republic, Hungary and Latvia experienced the resignation of governments at the beginning of 2009 .

As most transition countries have rapidly and convincingly adopted fully democratic institutions, especially in the CEE, the discontent of the "losers" (or the expectations of those who fear becoming such) can be expressed through the channels of representative democracy and of civil society. This may have several consequences: a slow down or temporary stop of the process of economic reforms (as in Fernandez and Rodrik, 1991); a reversal - through the electoral process - of the governing majority, ${ }^{5}$ and following that a reversal of the initial reforms, and an upsurge of populist and nationalistic ideas (as recently documented, e.g., by Rupnik, 2007 and Krastev, 2007). ${ }^{6}$ Therefore, subjective well-being and public attitudes towards transition are important not only as a measure of utility (indeed, many recent studies on happiness show that), but they are also crucial for the design and implementation of policies.

Indeed, a large theoretical political economy literature has shown that voters' opinions are crucial for the successful implementation of reforms, and that interest group coalitions may influence or even reverse the reform process (see Roland, 2002 for a comprehensive discussion). Both ex-ante and ex-post political constraints are important, as feasibility constraints may prevent reforms from being accepted, while policy reversal can occur after reforms have been already implemented (ibid). In general, a reason why reforms might be reversed is that they are not the outcome of optimal planning under full-certainty. On the contrary, they are often adopted as part of a trial-and-error procedure under aggregate (as well as individual) uncertainty, and in the absence of credible compensating mechanisms for losers. Thus reforms may be resisted ex-ante even when they would be ex-post beneficial (Fernandez and Rodrik, 1991) or, when enacted, they may face ex-post political opposition from those who have experienced economic losses. Rodrik (1995) shows that as the probability of getting a job in the private sector declines, state sector workers become anti-reform and vote for higher subsidies. However, he also observes that unemployment may strengthen support for reforms in situations where everybody is experiencing very high unemployment. As Fidrmuc (1999) observes, it is likely that workers in the state sector and those already unemployed will support rapid reforms only at the outset of transition, and will vote for a reduction in the speed of reforms later. On the other hand, workers in the private sector always benefit from, and hence also always vote in favor of rapid reforms. ${ }^{7}$ In general, this literature shows that reforms are endogenous to the economic outcomes of previous reforms, and in particular to their distributional

\footnotetext{
${ }^{5}$ Kornai (2006) computes that, out of 38 elections that took place in 8 CEE countries between 1989 and 2004 , in 30 cases the result has been one of "electoral dismissal". On the other hand, the political economy of discontent can take different routes in less democratic countries, such as several CIS.

${ }^{6}$ As the first author observes: “Populism is antiliberal but it is not antidemocratic. It gives voice to the losers of the reform" (Krastev, 2007, p. 60)

${ }^{7}$ In a parallel vein, but without entering into considerations of political economy, also Blanchard (1997) finds that there exist an optimal speed of mobility (rate of dismissals) from the state to the private sector that ensures a smooth transition to a market economy. If dismissals are either too fast or too slow then the process is endangered, and he argues that reforms may be reversed if economic gains do not accrue soon enough. He also argues that public support for reforms is U-shaped, following similar pattern in output and employment. Roland (2002) uses political economy considerations to argue for the importance of keeping unemployment as low as possible along the path of transition.
} 
impact (Kim and Pirttilä, 2006). The link between outcomes and reforms depends, among other factors, on the degree of (democratic) support for the reforms, which in turn depends on the net benefit that each individual receives from their implementation. In this framework, it is important to analyze the link between individual economic and labor market characteristics and attitudes towards transition reforms.

What determines these individual attitudes? Who is against transition? Are there differences across countries and institutions, or between the early and late stages of transition? Why is support for a system change lower in some countries than in others? These are the questions that we address in this paper.

While several studies have touched upon these questions, the majority of them either uses aggregate level data or is limited to only one country or one year. In addition, many studies have used indirect measures of preferences, such as those based on voting behavior; when the direct measures are available, individual-level data are scarce. Moreover, voting preferences are imperfect measures of attitudes towards reforms: since institutions are different across countries, such indirect measures may reflect both attitudes and institutions (Scheve and Slaughter, 2001; Mayda, 2006). ${ }^{8}$ In this paper we attempt to overcome these critiques by employing a unique data set of comparable surveys and using direct questions on attitudes towards economic and political systems in 14 transition economies over 1991-2004. We also provide several explanations for the lower support attitudes in some countries. To the best of our knowledge, this paper is the first one that analyses these questions using individual level data in a cross-country framework for this time span. Our data cover the entire period from the beginning of transition up to the first Eastern EU enlargement. The surveys allow us to distinguish between attitudes towards the economic and the political systems. By using individual level data and controlling for country specific effects we also alleviate the endogeneity problems that are likely to be present in aggregate data (Landier et al., 2008). Finally, as the suddenness and spread of the transformation were to a large extent unexpected and certainly unprecedented, these questions may to some extent be analyzed in the context of a (quasi) natural experiment of reform adoption (see also Landier et al., 2008; Alesina and Fuchs-Schueldeln, 2007). ${ }^{9}$

The main results of our study are the following. First, we document that support for both economic and political transition is indeed low in 14 countries, with the lowest numbers being in the CIS. Nevertheless, support for change in the political system is larger than that for the economic system. Second, consistent with the existing literature, we find that support is lower among the old, less skilled, unemployed and poor. In the majority of countries, attitudes towards transition to a market economy were more negative in the earlier phases than in 2004. In general, there are large similarities in the attitudes towards the economic and the political system, but also some significant differences. Third, we also find evidence of the importance of additional individual experiences and values, such as economic hardship during the transition, opinions on the speed of reforms, political preferences and preferences towards redistribution, ideology and social capital. Fourth, the degree of trust in political parties and parliament, individual

\footnotetext{
${ }^{8}$ A further difficulty arises in the context of transition and incomplete democracies, where people have not actually experienced the true "democracy" and "market economy", especially at the beginning of transition. In this case it is misleading to ask their opinions on, or their degree of satisfaction with, these institutions explicitly, as that may lead to a substantial bias (Mishler and Rose, 2000a,b). The survey questions on which we focus in this paper are not subject to these shortcomings.

${ }^{9}$ A few socialist countries had, however, begun to adopt a set of more limited market oriented economic reforms before 1990. The foremost example (outside the sample of countries studied in this paper) is China, where reforms were started around 1978 (See e.g. Lin, Cai and Li, 2002), but also Yugoslavia had adopted a widely decentralized system of enterprise management since the 1970s.
} 
preferences for state's responsibility and state ownership and, most important, preferences for secure jobs seem to explain some differences in support attitudes between the CIS and CEE countries. Finally, we show that country-specific institutions matter, as the unequal provision of public goods, widespread inequality, but mostly the quality of governance contribute to explain the lower support for transition in the CIS countries. Overall, the main findings are robust to changes in the definition and measurement of the dependent variables.

The remainder of the paper is structured as follows. Section 2 reviews the related empirical literature. Section 3 presents the data and discusses measurement issues, while the empirical model is presented in Section 4. The socio-economic determinants of the attitudes towards transition in 14 countries are examined in Section 5. Section 6 explores potential explanations for the lower support for transition in the CIS countries by analyzing the role of individual as well as of macro-economic and institutional variables. Section 7 concludes.

\section{Related empirical literature}

Several empirical studies have analyzed the determinants of support for reforms in transition countries, using different definitions of support and in reference to different countries and years. The first strand of empirical literature employs aggregate macro-level data to analyze these questions. Fidrmuc (2000) shows with county-level data that high unemployment is associated with less support for market reforms (defined as voting for the pro-reform parties ${ }^{10}$ ) in the Czech and Slovak Republics, Hungary and Poland. In contrast with the so-called responsibility hypothesis (when voters held the government responsible for the state of the economy), voters are found to be forward looking, since they support parties which they expect to deliver policies favorable to them.

Hayo (2004) analyzes support towards market reforms and the creation of a market economy in CEECs using macro data as well as micro data. Using Central and Eastern Eurobarometer data for 1990-1996 he shows that in only half of the countries there is a majority that supports the adoption of a market economy. He also finds a strong negative relation between inflation and support for market reforms, while unemployment has no significant effect. There is also some evidence that high speed of privatization and higher inequality are negatively correlated with pro-reforms attitudes. At the microlevel, the author finds a negative effect of unemployment on the support for market economy in 1995.

Kim and Pirttilä (2006), similarly to Hayo (2004), combine Central and Eastern Eurobarometer data (1990-1997) with macro data. They find that support for reforms is related to two groups of variables: past macroeconomic performance, "ex-post political constraints" (income inequality and inflation) and "ex-ante political constraints" (expected individual performance during future reforms). Support for reforms, in turn, affects positively the progress in reforms (measured by an index of the level of structural reforms). The authors conclude that transition reforms are not an exogenous process; on the contrary, their adoption depends crucially on political economy considerations.

\footnotetext{
${ }^{10}$ Tucker (2002) surveys 101 articles that study post-communist elections and voting in 16 political science and postcommunist area studies journals between 1990 and 2000 and reports that only 3 articles use individual data in multiple countries and multiple elections.
} 
Opper (2004) uses country-level data to analyze the determinants of progress in privatization in a political economy framework. She finds that financial constraints, distribution of political power and interest group pressure determine the progress in large-scale privatizations, but not in small-scale ones.

In a cross-country study, Doyle and Fidrmuc (2006) analyze support for EU membership in candidate countries. They use both regional macro data and individual data from the Candidate Countries Eurobarometer for 2002. They find that regions with low unemployment and high wages show greater turnout to referenda (albeit not greater support). Surprisingly, they also find that those who are most likely to benefit from the redistribution funds of the EU (i.e. individuals living in poor regions and those less well off) were more likely to oppose their country's membership or to abstain from voting in their countries' referenda for accession. Conversely, those individuals who are more likely to benefit from the new economic opportunities - the young, educated, skilled and those relatively well off - also display more pro-EU attitudes. These are the same characteristics that other studies find to be positively correlated with support for market reforms. Thus, as the authors argue, the accession to the EU may be perceived as the final critical step of the post-communist transition.

A recent paper by Landier et al. (2008) using World Value Survey data combined with country-level data investigates the determinants of and causes behind "capitalism aversion", measured by attitudes towards private ownership, private profits and competition. The authors provide evidence for support of both the "self-interest" and "slow learning" hypotheses and also show that cultural factors matter. In addition, the paper also provides some evidence that pro-market opinions affect the nature of economic institutions.

Another strand of the empirical literature uses micro data to analyze individual preferences towards reforms in a single country. Doyle and Fidrmuc (2003) using survey data for the Czech Republic (19901992 and 1993-1998) show that unemployment began to have an effect on voting in the Czech Republic during the later stages of transition, when winners and losers had already been identified. They also find support for the so-called "responsibility hypothesis" (that is, voters with low incomes or those living in areas with high unemployment show less support for the pro-reform parties). As both individual and regional unemployment variables are significant, they do not find conclusive evidence to discriminate between the so-called individualist versus sociotropic behavior, which is often analyzed in this sort of studies. In another study for the Czech Republic, Earle and Gehlbach (2003) analyze the role of privatization for individual attitudes towards economic reforms and democracy. Using data from the Survey of Economic Expectations and Attitudes from 1996, they show that receiving property through restitution and retaining shares acquired through the voucher program is strongly associated with support for reforms, while participation in voucher privatization had little impact. Moreover, the magnitudes of the impacts of privatization experiences were substantial, which suggests a significant impact of this policy design on citizens' support for transition.

Valev (2004) studies the effect of unemployment on voting behavior in Bulgaria and finds a small effect. Although high unemployment reduces somewhat the support for market reforms, in locations with high unemployment unemployed people demand more, rather than less, reform, which is consistent with the Rodrik's (1995) hypothesis. In addition, Valev (2004) shows that many voters believed that high unemployment was a short-term cost necessary to implement market reforms, and that, accordingly, they voted for a pro-reform party. The author also argues that these results have important implications for the Optimal Speed of Transition literature, since voters supported rapid rather than gradual reforms. 
Eble and Koeva (2002) provide evidence on the determinants of individual reform preferences in Russia after the August 1998 crisis, using Russian Longitudinal Monitoring Survey Round 8 data. The authors use two measures of preferences: opinions about the reform process in general and attitudes towards market reforms in particular. They confirm that individual attitudes towards reform are affected by individuals' economic gains or losses during transition (the so-called "economic hypothesis"). They also find that some societal groups, such as younger individuals, are more flexible in adapting to changes than older individuals (the so-called "ideological hypothesis"). Finally, their findings show that local economic conditions matter: people who live in high-arrears regions are more likely to be against the reform process; and also the regional income level, ethnic composition, oil production and crime rates (but not the unemployment rate) exert a significant effect on reform attitudes.

Jackson et al. (2003) analyze confidence in state firms vs. de novo private firms in Poland using both aggregate and survey data from three Polish elections. They show that support for pro-reform political parties is stronger for these private firms, for the individuals they employ and for the residents in areas where these firms are established.

Finally, Denisova et al. (2007) analyze the determinants of opinions in favor of a revision of privatization in 28 transition countries in 2006 using individual-level data from the Life in Transition Survey. The authors find that respondents with less human capital, employed in less skilled jobs, older individuals, those with poorer health and with a vocational education degree are more likely to be in favor of revising privatization. In addition, significant and sustained economic hardships experienced during transition (e.g., food cuts, forced asset sales and wage cuts) are associated with greater support for revising privatization. They also find that the quality of institutions, such as governance, democracy and private ownership as well as income inequality affect the link between transition-related experience and support for the revision of privatization. ${ }^{11}$

Related literature examines subjective well-being in transition countries. Blanchflower (2001) uses Central and Eastern Eurobarometer data to estimate wage curves and well-being regressions in 23 transition countries over 1990-1997. He finds that happiness is, in general, low in these countries, and that satisfaction with democracy is U-shaped in age and is the lowest among the least educated, females, and the unemployed. He also analyzes attitudes towards market reforms and finds that support for these reforms followed a U-shaped pattern across years, and is lowest in the CIS countries, among the least educated, females and the unemployed and is U-shaped in age. Similarly, Sanfey and Teksoz (2007) using World Value Survey data find that individuals in transition economies have significantly lower life satisfaction compared with those in non-transition countries, and that in several countries life satisfaction has returned to the pre-transition levels after a drop in the mid-1990s. The authors find that people are in general happier in countries that have made more progress in transition and where inequality is lower. They also show that the most vulnerable groups include older individuals with obsolete skills and those with limited education. In addition, the self-employed have satisfaction levels as high as, or higher than, full-time employees, suggesting that entrepreneurship can be a rewarding option in transition. A recent paper by Guriev and Zhuravskaya (2009) using data from the World Value Survey and from the Life in Transition Survey arrives at similar conclusions. The authors also provide several reasons to explain why

${ }^{11}$ Blanchflower and Freeman (1997) using ISSP data compare attitudes of workers in the former communist countries (Bulgaria, Czechoslovakia, East Germany, Hungary, Poland, Russia and Slovenia) to those in Western countries. They find that citizens of ex-communist countries report a greater desire for egalitarianism, less satisfaction with their jobs, more support for trade unions and state intervention than do Western citizens. 
life satisfaction is lower in transition countries. In particular, the depreciation of human capital, the deterioration of public goods, income volatility and social injustice are quite relevant in this context. Once these effects are controlled for and differences in samples are accounted for, the difference between transition and non-transition countries disappears. Easterlin (2008) also uses World Value Survey data and finds that life satisfaction has indeed followed the same U-shaped pattern as GDP in transition economies, but also that the recovery falls short of that of GDP by 1999. The largest loss in life satisfaction is experienced by less educated and older individuals. He also suggests that transition has raised satisfaction with material living levels, but has decreased satisfaction with employment, health and family security.

Finally, the sources of popular support for political regimes in general and democracy in particular have been analyzed widely by political scientists using, among others, data from the World Value Survey and New Democracy Barometer (see, for example, Rose, 2007, Lazar, Mishler and Rose, 2007, Mishler and Rose, 2002, Mishler and Rose, 2000a and b). Their findings indicate that, in general, most of the variance in support for the new political regime may be explained by factors related to the economic and political performance, followed by the communist legacy. These studies also argue that citizens learn about the new regimes in both democratic and undemocratic countries, and that their assessments may change with the passage of time. One implication of this "lifetime learning model", a political economy model of regime support (Mishler and Rose, 2002), is that, as time goes by, we should observe the emergence of a divide between citizens, according to their personal experiences and characteristics. Indeed, they also find that most vulnerable economic groups express less support for the new regime (Mishler and Rose, 2008; Lazar, Mishler and Rose, 2007). Evaluations of the economic system and the political regime may also influence each other, while domestic economic conditions (GDP growth) and political institutions (civil and political liberties, the characteristics of the political and electoral systems) have a separate impact on these evaluations (Mishler and Rose, 2008). One interesting conclusion from these studies is that high support for the past regime is more likely to reflect a nostalgia for the past than a desire to abandon economic reforms and to return to communism, since the proportion of those willing to return to communist rule is low even among those individuals who rank the communist political regime favorably (Rose, 2007).

Our paper complements and adds to this literature in several ways. We analyze individual support for transition, controlling for a large array of individual characteristics, taking advantage of employing a unique large micro dataset which covers 14 transition countries over an extended period of time (19912004), which we have merged with the corresponding macro-economic and institutional variables. We also distinguish between determinants of support for the economic and political system and attitudes for the current and the past systems. Finally, we document cross-country differences in the support for transition and, following the approach of Guriev and Zhuravskaya (2009), we test for potential explanations of these cross-country differences.

\section{Data and descriptive evidence}

\section{a. Data and sample selection}

The individual data used in this paper come from the New Barometer Surveys (New Democracy Barometers). These are representative surveys of the populations in transition countries consistently 
collected over time by the Centre for the Study of Public Policy (CSPP) at the University of Aberdeen and the Paul Lazarsfeld Society, Vienna (see Data Appendix for the data acknowledgements and citations).

As each survey round contains a large number of common questions, which are maintained across time and countries, the set of available surveys constitutes a unique dataset that allows meaningful crosscountry comparisons across several years. This allows us to identify trends in political and economic transformations and also, given the composition of the questionnaires, to analyze the determinants of individual attitudes in the face of such changes. Surveys are undertaken independently from governments and face-to-face interviews are performed by trained interviewers working for established national research institutes in the national language (with the exception of the Baltic States, Belarus, and Ukraine, where Russian was also used). The survey includes nationwide multistage random samples of around 1,000 respondents per country (in Russia - around 2,000) over 18 years old.

We have merged several waves of the New Europe Barometer, the New Russia Barometer and the New Baltic Barometer data. Our sample includes 14 transition economies, with the surveys taking place in several waves between 1991 and 2004. Ten countries in our sample became members of the EU with the 2004 or 2007 enlargements (Bulgaria, Czech Republic, Estonia, Hungary, Latvia, Lithuania, Poland, Romania, Slovakia and Slovenia), Croatia is currently a candidate for EU membership, while three countries are members of the CIS (Belarus, Russia and Ukraine).

The set of explanatory variables employed in the regressions below includes standard socio-economic indicators used in the literature, such as gender, age, education, marital status, urban residence, employment status and household income. In addition, we have also collected data on macro-economic variables and political institutions. In the final sample we keep individuals with non-missing information on the key explanatory variables. Table A2 in the Appendix presents sample size by country. Definitions of the variables and details on the sources, usage and copyright of the data are given in the Data Appendix.

In the survey, there are several questions which aim at representing the degree of individual support (or opposition) towards the process of transition. Some questions are focused on the present-day system, others on the past system, i.e. the planned economy or socialism. For the purpose of this paper we focus on the responses to the following sets of questions, which were included in all surveys:

\section{Economic evaluation:}

Q.1 "Here is a scale for ranking how the economy works (from +100 at top to -100 ).

a) Where on this scale would you put the socialist economy before the revolution of 1989 / perestroyka?

b) Where on this scale would you put our current economic system?"

Political evaluation:

Q.2 "Here is a scale for ranking how our system of government works (from +100 at top to -100).

a) Where on this scale would you put the former communist regime / political system before perestroyka? 
b) Where on this scale would you put our current system (with free elections and many parties)?"12

As a first step, let us examine the patterns of responses to these questions across time and countries (see Figure 1 and Table A.1 in the Appendix).

[Insert Figure 1]

Figure 1 shows the proportion of positive, negative and zero evaluations of past and present economic (left panel) and political (right panel) systems for 1993 and 2004 . Focusing first on the economic system reveals that a majority of respondents valued negatively the present system in 1993, while in 2004 a majority gave positive evaluations. Regarding the past economic system, a majority of respondents gave positive scores both in 1993 and 2004. For the political system the picture is somewhat different, as a majority of individuals evaluates positively both the past and the present system in both years, and interestingly the proportion of positive answers increases by 2004 . Note also that zero evaluations constitute only a small proportion in the overall poll. Looking in more detail at each country (Table A.1), the following trends can be identified. First, at the beginning of the period (1991/93) in most countries the average evaluation of the present economic system was negative (13 countries vs. 1 - the Czech Republic). By the end of the period (2004), the odds were almost even ( 8 negative versus 6 positive), but in the meanwhile a considerable revision of the past had taken place. While at the beginning of the period, evaluations of the past economic system were on average positive in 9 countries, by 2004 this is true for 13 countries (the Czech Republic being the only one with a negative evaluation).

Second, evaluations concerning the present political system, on the contrary, are on average positive since 1991/1993. In addition, out of the five countries where a majority of responses was initially negative, four were at that time non-democratic (or non fully democratic): Belarus, Croatia, Russia and Ukraine. Moreover, the number of countries with positive attitudes towards the present political system has increased in 2004 (11 versus 3), but at the same time (in 2004) the number of positive assessments of the previous political system has also increased (again: 11 versus 3).

\section{b. How to measure support for transition?}

In principle, there are several alternative ways in which the evaluations presented in the previous paragraph can be used to formulate an appropriate dependent variable for our analysis. For instance, should we focus only on individual judgments about the present system? Or instead on a comparison between the evaluations for the present and the past? Intuitively, being interested in modeling the support for transition, a relative measure seems to be more appropriate, as it directly reflects support for the current system relative to the past one. Moreover, the answer to these questions is related, inter alia, to whether the revision of opinions about the previous regime reflects a (selective) forgetfulness of the past or a delusion about the present or, indeed, a mixture of both. Our a priori is that judgments about the past are meaningful, and that evaluating the past more favorably is part of the same process that results from a delusion about today's experience. Accordingly, a judgment about the past is not only a historical assessment, but it also conveys information about the evaluation of the present system. In other words, statements about the past and the present are not independent of each other, but rather

\footnotetext{
12 Note that the questions have been framed in accordance with country-specific situations. For example, "free elections and many parties" are not mentioned in the Russian questionnaire, and the questions are only about "the current political system" and the economic or political systems "before perestroyka".
} 
reinforce each other. One way to take this into account is to compute our dependent variable by taking the difference (or "distance") between the responses to Question b (present) and to Question a (past) for the economic and political systems evaluations, respectively. Thus, a larger positive (negative) difference implies a larger positive (negative) assessment of the present regime relative to the former one (in the economic or governmental dimensions, respectively). The larger this distance, the more an individual is positive about the current state of the economy or polity relative to the past, and thus, we assume, the more supportive he or she is for transition and for the reforms that have been adopted.

In this context, note that differences in responses across countries may also arise due to different interpretations of the reference scale $(-100 ;+100)$ in different countries and by different individuals, as they may be related to country-specific factors, such as culture. To this aim, we also standardize our dependent variable dividing it by its country (and year) specific standard deviation and control for country-specific effects in the regressions below. In this way we weight individual responses by a country and year specific variance, thus giving more weight to countries with relatively homogenous responses. $A$ related problem that arises when using subjective data is that individual responses may be affected by several factors, such as the ordering or the exact wording of the questions or individual differences in the perceptions of the scale, which may introduce a measurement error into individual attitudes (Bertrand and Mullainathan, 2001). Note that the questions on the economic and political systems in our survey are usually asked at the beginning of the corresponding sections on the economy and public affairs, before the questions on the personal (or family) economic situation or on political preferences. Note also that taking differences across individual answers for the same person may difference away such individualspecific and evaluation-invariant factors as pessimism or different individual perceptions of scale, thus potentially reducing the biases associated with it. ${ }^{13}$

A final criticism, using the distance variable, is that it does not take into account whether the absolute evaluations of the present or the past are positive or negative. In section 4 we will test the robustness of our results also in this respect.

\section{[Insert Figure 2]}

Before proceeding to a more formal analysis, let us take a further look at the evolution of the support variables across time and for the individual countries. Figure 2 shows the developments over time of the support for the present and past systems as well as the corresponding "distance". Support for the past economic system is quite high across 1991-2004, while it is much lower for the past political system (and is negative at the beginning of the 1990s). There is also an increase over time in the ranking of both past and present systems. Moreover, the support for the past economic regime is always higher than for the present economy, while the difference between the evaluations of past and present political systems is large in 1991, but small from 1992 onwards. As a result, our "distance" measure has a U-shaped profile for the economic system, while for the political system it decreases until 1998 and increases rather slowly afterwards. The U-shaped pattern in the support for economic transition seems to be in line with the Blanchard's hypothesis and several studies mentioned above. However, only in a few countries it follows the development of GDP over time (see Appendix Figure A1). It is also worth noting that the support for

\footnotetext{
${ }^{13}$ In general, we have extensively tested the sensitivity of our main results to alternative definitions of the dependent variable. To this purpose, we have used as a dependent variable non-standardized distance and have experimented with individual evaluations of only the present or the past economic or political systems. In addition, we have used responses to a question which was asked at the end of the interviews (see below). Overall, our main results were robust to changes in the definition of the dependent variable.
} 
change in the political system ("distance") is larger than for change in the economic system. This is consistent with the political economy approach that suggests that more popular reforms should be implemented first, and with the observation that democratic reforms preceded economic reforms in all Central and Eastern Europe, since support for democracy was larger than for economic reforms (Roland, 2002).

As these aggregate changes may be driven by changes in the composition of countries in our sample throughout the period, in Figure 3 we plot the evolution of "distance" in different countries. In general, this figure confirms the previous observations. It also shows that the Czech Republic is the country with the largest support for both the economic and political transition, while Ukraine is the country with the lowest support. ${ }^{14}$ Figure 3 also suggests that support for the economic transition is increasing in most countries, while support for the political transition is either constant or even decreasing.

\section{[Insert Figure 3]}

Another way to look at these evaluations is to adopt a classification developed by political scientists that is available in our dataset. The classification is explained in Table $1 \mathrm{a}$, and it is used in Table $1 \mathrm{~b}$ to classify the countries according to country averages. Again, the results are quite striking: the Czech Republic is the only consistently "pro-market" and "pro-democracy" country. Regarding the economic system, most countries are, on average, either "negative" or "nostalgic". Only a few are "positive", meaning that citizens give a positive evaluation to both the socialist and the market economy. For the political system, similarly, in the majority of countries, the responses are either "reactionary" or "compliant".

[Insert Table $1 \mathrm{a}$ and Table $1 \mathrm{~b}]$

These preliminary findings also suggest that there might be some correlation between the attitudes towards the economic and the political system. Table 2 shows that this is indeed the case: for instance, while among all respondents those who are "nostalgic" about the socialist economy represent 43 percent, among those who are politically reactionary the proportion of "nostalgic" individuals is 81 percent.

[Insert Table 2]

Summing up, on average, citizens do not seem to give a favorable evaluation for the economic system they live in, and they seem to have regrets for the past. On the other hand, on average, they appear to be reasonably satisfied with the present political system, but in some instances they still do not see it as an improvement over the past. This is true, in particular, for the current CIS members, but also several other countries, such as Hungary, Slovakia, Slovenia, Latvia, Bulgaria and Croatia express a negative evaluation of the political "distance" in 2004. These findings, however, should not be interpreted as reflecting a desire to return to Communism, as among the respondents who give positive evaluations to the past economic or political system, only about 30 percent would actually agree to "return to communist rule". The fact that the support for transition is quite low may appear somewhat puzzling, at least prima facie, if we compare these responses with the evolution of most standard macroeconomic and institutional indicators, especially in the new EU member states. Most indicators show a consistent improvement across time in all countries (see Appendix Table A.4), although there are some exceptions,

\footnotetext{
${ }^{14}$ The highest support in the Czech Republic is remarkably consistent with one of the "political economy puzzles in Central Europe" (Roland, 2002, p. 44), namely, the higher stability of the government of Vaclav Klaus in the Czech Republic (until very recently), compared with governments in other transition countries; the fact that the Czech Republic has managed to maintain lower unemployment rates could be one of the potential explanations.
} 
as Gini inequality index, Governance Indicators and life expectancy have indeed deteriorated in several countries. These aggregate differences, however, may be confounded by differences in individual characteristics and transition experiences. Moreover, country-specific macroeconomic policies and institutions may also affect the individual support for transition. We examine the role of these factors in the sections below. Although we cannot interpret these as causal relationships, documenting the role of these factors in a descriptive manner provides a useful picture of the situation in these countries and sheds additional light on the overall political economy of transition.

\section{The empirical model}

We model individual support for the economic or political transition assuming that it may be influenced by three sets of explanatory variables. First, individual socio-economic characteristics matter as "winners" (also potential) are more likely to support the transition process, while "losers" are less likely to support it. Second, ideology, individual preferences and values (usually unobservable) may also influence individual support for transition. Note that controlling for ideology and transition-related experiences may alleviate the omitted variables problem as these variables could potentially confound the results. On the other hand, individual values and preferences are subjective measures themselves and thus are likely to be endogenous, i.e. shaped by individual socio-economic characteristics, the performance of the system and the inherited individual culture. Therefore, caution is needed when interpreting the results from the regressions that include such subjective measures. Nevertheless, it is interesting to explore the correlation between these variables and support for transition. Third, country-specific indicators for economic performance and institutions are also likely to be correlated with individual support for transition.

We begin with the following simple baseline specification:

$Y_{i j t}=\beta X_{i j t}+\delta_{j t}+\varepsilon_{i j t}$

were $Y_{i j t}$ is our support for transition measure of individual i in a country $\mathrm{j}$ in year t, $X_{i j t}$ is a vector of standard individual socio-economic and demographic characteristics, $\delta_{j t}$ are the interactions between country-specific and year fixed effects and $\varepsilon_{i j t}$ is a random error term, which ideally should not be correlated with the rest of the variables. Incorporating into this simple model a set of variables reflecting individual (subjective) preferences and values leads to the following more general specification:

$Y_{i j t}=\beta X_{i j t}+\varphi V_{i j t}+\delta_{j t}+\varepsilon_{i j t}$

where $V_{i j t}$ includes subjective perceptions and preferences for political regimes, redistribution of income etc. As discussed above, $V_{i j t}$ may in turn be affected by individual characteristics as follows:

$$
V_{i j t}=b X_{i j t}+\gamma Z_{i j t}+d_{j t}+\eta_{i j t}
$$


where $Z_{i j t}$ now includes the inherited or predetermined ("cultural") components of values and preferences, and $\eta_{i j t}$ is a random error term. This system of equations generates the following reduced form:

$Y_{i j t}=B X_{i j t}+\Gamma Z^{\prime}{ }_{i j t}+D_{j t}+E_{i j t}$

where $B=\beta+\varphi b, \Gamma=\varphi \gamma, E_{i j t}=\varepsilon_{i j t}+\varphi \eta_{i j t}$, and $Z^{\prime} \subseteq Z$.

Thus, the parameters estimated in equation (4) have to be interpreted with caution, since the estimates are certainly not structural. In addition, several variables in $X_{i j t}$ are also likely to be endogenous, as there may still exist unobservable individual characteristics that affect both attitudes towards transition and, for instance, education, labor force status or household income. Having repeated cross-sectional data unfortunately precludes us from accounting properly for individual-specific effects. In Section 5b, we employ equation (2) and include directly variables measuring explicit values and preferences into the model. Although, again, these variables are endogenous, it allows us to measure the correlation between support for transition and preferences for redistribution or trust in political institutions, which is interesting per se. Overall, although it is difficult to draw causal inferences, after having controlled for individual characteristics and preferences as well as for country-specific effects and trends, the results are at least suggestive and provide a descriptive picture about the "winners" and "losers" from transition.

Finally, in Section 6 we introduce macro-economic and institutional variables into our baseline model in order to capture country-specific performance and institutions as well as to assess whether they contribute to explaining the lower support attitudes in the CIS countries:

$Y_{i j t}=\beta X_{i j t}+\theta W_{j t}+\mu_{j}+\varphi_{t}+\varepsilon_{i j t}$

where $W_{j t}$ are country-specific variables that vary over time, $\mu_{j}$ are time-invariant country fixed effects and $\varphi_{t}$ are year fixed effects.

We use the standardized "distance" measure as the dependent variable for the reasons discussed above, but also experiment with modeling the evaluations of the past and present systems separately. In Section 5 a below, we first estimate equation (1) for economic and political support attitudes separately by OLS (Tables 3 and 4), and then re-estimate this model allowing for the correlation between the two dimensions (Table 5). We also perform several sensitivity checks in order to explore the robustness of the definition of our dependent variable (Tables 6 and 7). Additional objective variables and subjective preferences are included into our model in Section 5b (Tables 8 and 9). Country-specific regressions are analyzed in Section 5c (Tables 10 and 11). Finally, we explore potential explanations for the lower support for transition in the CIS countries, including macro-economic variables and institutions, in Section 6 (Tables 12, 13, 14).

\section{Who is against transition?}

\section{a. Determinants of support for change in the economic and political systems}


The transition process has generated economic "winners" and "losers" from transition (Brainerd, 1998, Terrell, 1999). It is likely that those who have not benefited from or could not adapt to the changing environment would express lower support for transition. For example, in line with the literature, older individuals, women and those unemployed and with obsolete skills can be expected to oppose the transition reforms because of the decreased social security and increased unemployment risks. It is also likely that individuals who had experienced the labor market under socialism will have different support attitudes in comparison to the younger cohorts. On the other hand, young, educated and more wealthy individuals are likely to support the transition process as potentially they may benefit or may have already benefited from the new opportunities, including those in the labor market that have been brought about. Finally, individuals' experiences during transition, such as economic hardship, influence their subjective wellbeing (Guriev and Zhuravskaya, 2009), and thus are also likely to affect their evaluations of the transition.

Table 3 reports the baseline equation (1) estimates for the evaluations of the economic system, and Table 4 shows the analogous regressions for the political system. In both tables, the dependent variable in column (1) refers to the evaluations of the past system, in column (2) the present system, and in columns (3) and (4) to their "distance". While in column (3) we control for separate country and year fixed effects, in column (4) we include the full set of country-year interactions as specified in equation (1). In general, we expect that those individual characteristics that affect positively (negatively) the evaluations of the past, should also affect negatively (positively) the evaluations of the present and also their "distance".

\section{[ Insert Table 3 and Table 4]}

Let us first focus on the support for the economic transition (Table 3, columns 3-4). Several individual characteristics significantly affect the support attitudes. In particular, females seem to discount the present versus the past more than males, and age, education, urbanization and income also matter. In general, these results are consistent with the "losers vs. winners" approach and confirm that support for transition is lower among the old, unemployed, less educated individuals, those living in rural areas and having the lowest household income. Note, in particular, that having a university degree increases standardized "distance" by roughly 0.30 points, ${ }^{15}$ and so does belonging to the 4 th (upper) income quartile, while being unemployed decreases it by 0.16-0.17 points. ${ }^{16}$ Regarding age, being older at the time of the interview is in general related to lower support for transition, relative to individuals younger than 29 years old. In addition, there is a separate effect of belonging to a young cohort, i.e. being 18 years old or younger in 1990 (and thus presumably not having experienced the labor market under socialism), which increases support for transition by 0.09 points. Coefficients on country-specific effects, in general, confirm the descriptive evidence from Figure 3. Relatively to Slovenia, individuals in the Czech Republic, Poland and Croatia are significantly more positive about transition, whereas those in the CIS countries are most negative ceteris paribus (see column (3)). There seems also to be an increasing trend in support for change in the economic system, with support being, in general, higher in 2004 than in 1990s. Note also that despite the introduction of the country-year interactions, the sign and significance

\footnotetext{
${ }^{15}$ Notice that while present and past have unit variance by construction, their difference (distance) does not possess this propriety, so we cannot interpret these coefficients in percentage points of a standard deviation.

${ }^{16}$ To make the quantitative interpretation more intuitive, the corresponding numbers for the unstandardized distance measure are around 20 and 12 points, respectively, on a scale ranging from -200 to +200 .
} 
of the individual characteristics remain generally unchanged. ${ }^{17}$ The evaluations of the political system (Table 4) give very similar results, with the exception of the pensioner variable, that is no longer statistically significant, and city residence, that becomes marginally significant, while the dummy for Romania becomes positive. In addition, there is no evidence of the increasing trend in support for the political transition. However, it should be noted that time dummies in these regressions have to be interpreted with caution, since the composition of the sample with respect to countries changes throughout 1991-2004. It is, therefore, difficult to interpret them consistently in a comparative way across the whole period, and a separate analysis on a country-by-country basis is needed (see Section $5 c) .18$

In columns (5) and (6) we restrict the sample of observations in several ways in order to get a better "feel" for the appropriateness of our chosen dependent variable. Column (5) shows that our results are, in general, sharper when we limit the sample to the two extreme subgroups of "nostalgic" ("reactionaries" in Table 4) and "pro-market" individuals ("democrats" in Table 4). Note that the overall fit of the model is also better in these regressions. If instead we only look at the "pro-market" ("democrat" in Table 4) group, most individual characteristics are not significant. Overall, the results in columns (5) and (6) seem to suggest that the relative support for transition is mainly driven by the contrast between those individuals who are "nostalgic" about the past (or "reactionary") and those who are "pro-market" (or "democrat"). This, in general, reinforces our interpretation of the dependent variable. $^{19}$

An additional concern with individual evaluations of the aggregate economic or political system is that individuals may value differently changes in their own or family economic situation and changes in the country's economic situation. To obtain additional insights on this issue, we have re-estimated the baseline equation of Table 3 for five different sub-groups. These were selected on the basis of their responses to the following question:

"When you compare the overall economic situation of your household with what it was before the big transformation in the economy, would you say that in the past if was: much better / a little better / about the same / a little worse / a lot worse?"20

Indeed, as it is shown in Figure 4, those who report that their family economic situation is worse now than it was in the past, give consistently lower ranking to the overall country's economic transition. In general, the effect of individual characteristics on the support for economic change does not change much between the five groups (not reported here, but available upon request). However, it is interesting

\footnotetext{
${ }^{17}$ Interaction terms are in general significant (not reported, but available on request).

${ }^{18}$ Since our dependent variable is, in principle, ordered it is also possible to estimate the ordered probit model. We have estimated such model, coding our "distance“ measure into four ordered categories (from - 200 to - 100, from 100 to 0 , from 0 to +100 , from +100 to +200 ). The qualitative results were identical (available upon request). However, since the quantitative interpretation is somewhat more complicated in this model, we have decided to present the results for the OLS.

${ }^{19}$ We have also estimated the baseline model keeping in our sample only those individuals who were older than 18 years of age in 1990, since they have had an experience of the old system and thus can compare it directly with the new one. The estimates of the rest of the coefficients remained unaffected (with the only exception of the student variable that became insignificant in the equation for the political transition). In addition, we have experimented with excluding Russia or Belarus from the sample, and the main results remained qualitatively the same (all results are available upon request).

${ }^{20}$ Note that in some countries and some years this question was asked in reference to "five years ago" rather than to the period before the transformation.
} 
to observe that, for the group that thought that the past was "a lot worse", being unemployed (being in the highest household income quartile) lowers (raises) by a considerable amount their evaluation of the change. People who think that in the past it was worse are most probably expecting the largest positive changes, so they are likely to react more strongly to either the disappointment of being unemployed, or to the benefit of having a large income. Overall, these additional results suggest that the evaluation of economic transition does not reflect only or predominantly the subjective experience of the interviewees, as measured by the economic situation of their household.

[Insert Figure 4]

The results from the baseline models in Tables 3 and 4 suggest that individual evaluations of the economic and political system are related in the same way to the same set of individual characteristics. That is, it is likely that individual evaluations of the economic and political systems are correlated. Indeed, the raw correlation between these two outcomes is high and equal to 0.63. Table 5 reports estimates of the baseline equations, allowing for correlated errors across equations and using the seemingly unrelated regressions (SUR) method. Overall, the results from OLS estimates are generally confirmed, although there is now some gain in efficiency for individual coefficients.

[Insert Table 5]

As was discussed in Section 3, it is not clear a priori whether absolute judgments expressed about the present or the past system are a suitable measure of the support for transition, or whether instead one should focus on the relative measure, i.e. comparing present versus past judgments. Indeed, as was mentioned in Section 3b, another potential criticism against using the distance measure is that it does not take into account the "absolute" evaluation of the current or of the past systems given by the respondents. For instance, the same distance of 70 could characterize someone who likes both the past and the present (past $=30$; present $=100$ ), someone who dislikes them both (past $=-100$; present $=$ 30) and someone who dislikes the past but is reasonably satisfied with the present ( past $=-40$; present $=30)$. As these absolute evaluations might contain additional information, we have used the classification in Table 1 proposed by political scientists to divide our sample in eight different sub-groups, four for the evaluation of the economic system and four for the political system. Which characteristics account for individual respondents placing themselves in any of these groups? To address this question, in Table 6 we report the marginal effects from the multinomial logit regressions for "positive", "promarket" and "nostalgic" groups relative to the "negative" group for the evaluation of the economic system (columns 1-3) and for "compliant", "democrat" and "reactionary" groups relative to the "skeptic" group for the political system (columns 4-6).

\section{[Insert Table 6]}

Several interesting facts emerge from this table. First, only few individual characteristics are significant for the "positive" and "compliant" groups. Second, the impact of individual characteristics on the likelihood of being "pro-market" and "democrat" is qualitatively opposite to the impact for "nostalgic" and "reactionary" groups. For instance, the likelihood of being "pro-market" (see column 2) is significantly lower for females, unemployed and pensioners and is decreasing with age. On the other hand, university graduates are 7 percentage points more likely to be "pro-market" relative to those with elementary education, and so do individuals from the highest household income quartile. Looking at the political system and, again, focusing on the group of those who support the change to the new system (i.e. 
"democrats", column 5), we find a very similar impact of individual characteristics, with the exception of the urbanization and pensioner variables that become insignificant. On the other hand, several characteristics have a stronger effect on political attitudes. For example, university graduates are, on average, 12 percentage points more likely to belong to the "democrat" group, while females or unemployed are, on average, 4 percentage points less likely to belong to this group ${ }^{21}$

Overall, the results from the multinomial logit analysis reinforce those from the OLS regressions above. Individual characteristics shape the pattern of individual evaluations regarding the economic and political system in a strong and plausible way. Country effects are also large and consistent across different specifications. Most important, this analysis shows that those characteristics that determine individual likelihood to belong to a "pro-market" group go in the same direction as those that drive his or her attitudes towards support for transition. In other words, those who have lower support attitudes are, consistently, less likely to belong to the "pro-market" groups, and vice versa. ${ }^{22}$ Therefore, this validation exercise adds credibility to the interpretation of the OLS regressions as modeling support for reforms or, at least, for transition.

Finally, before moving to the next section, several additional sensitivity checks were undertaken and are reported in Table 7. First, we have estimated the baseline models for the economic and political system using the non-standardized distance as a dependent variable (see columns (1) - (4)). In general, the results are qualitatively unchanged and can be interpreted quantitatively now in terms of the corresponding points on the scale from -200 to +200 . Second, we have used a different binary dependent variable that is equal to 1 if an individual agrees with the statement "We should return to Communist rule". In general, the characteristics that affect positively (or negatively) the probability of agreeing with this statement are the same as those that decrease (or increase) support for transition in Tables 3 and 4.

\section{[Insert Table 7]}

Summing up this section, we find robust evidence that support for both economic and political transition is lower among older individuals, unemployed, less educated, and those living in rural areas or belonging to the lowest household income quartiles. We also document that support is the lowest in the CIS countries. Different definitions of the dependent variable add credibility to interpreting the overall results as modeling support for transition. Consistent with the existing literature, our results indicate that the support for transition is indeed low among those who are likely to having lost from it. Note, however, that although the same individual characteristics that determine lower support attitudes for transition also affect the willingness to return to communism, the low average support for the new regime relative to the old one does not necessarily imply that a large proportion of individuals would actually like to "return to Communist rule" (see above and Rose, 2007). There is also considerable heterogeneity across countries in support attitudes as suggested by large and significant country-specific effects. In addition, in order to identify trends in these attitudes, one would need to undertake a country-specific analysis, since the composition of the countries' sample changes throughout the period. We turn to such analysis in Section $5 c$.

${ }^{21}$ When estimating this model with country-specific effects and year dummies, the results were similar to those previously identified, with the Czech Republic having the largest positive effect and the CIS countries having the largest negative effect, and the probability to belong to the "pro-market" group being lower in 1990s than in 2004.

22 To make this statement more clear, consider as an example the fact of being unemployed. Our results suggest that this: (i) will lower the probability of being "pro-market", (ii) will increase the probability of being "nostalgic", and (iii) will also decrease the overall support for transition, i.e. our "distance" measure. 


\section{b. The impact of additional characteristics}

Before turning to a country-specific analysis, however, it is important in these kinds of studies to properly control for heterogeneity in (usually unobserved) individual preferences, transition experiences and ideology. In this section, we exploit the richness of the data at our disposal and attempt to control for these additional characteristics.

As noted above, having experienced individual hardship during the transition process may influence individual happiness (Guriev and Zhuravskaya, 2009) and thus individual evaluations of the relative performance of the economic and political systems. Another potential variable that is likely to be associated with individual evaluations of reforms is the speed with which the reforms were actually implemented. As suggested in the literature on the "Optimal Speed of Transition" (Aghion and Blanchard, 1994) and on the desirable sequencing of reforms (the "big-bang vs. gradualism debate", see, e.g., McMillan and Havrylyshyn, 2004, Murphy, Schleifer and Vishny, 1992 and Roland, 2002), reforms can either (be perceived to) go too fast or too slow, and in each case the individual assessment of the economic and, possibly, of the political process would become more unfavorable. The extent of corruption in a country may also confound our results, since it may negatively affect individual attitudes towards the process of reforms in general. As communism is believed to have shaped cultural preferences towards redistribution (Alesina and Fuchs-Schundeln, 2007), it is likely that such preferences may in turn be correlated with individual attitudes towards transition from communism. In general, in this literature it is important to properly control for the role of ideology and political preferences, as these definitely affect individual attitudes towards transition from communism. Finally, following the literature on the importance of "informal" institutions and of social capital, we have also experimented with including different measures of trust. Note, however, that as discussed above, many of these variables are subjective measures and many (if not all) are likely to be endogenous. Nevertheless, even interpreting them as correlations provides additional useful insights.

[Insert Table 8 and Table 9]

Tables 8 and 9 show the estimation results when we introduce these variables into our baseline model. First, to proxy for individual hardship experienced during the transition, we construct two indicators, both of which refer to the year previous to the interview. The first variable (see column 1 in both Tables), measures the total number of weeks during which a person was either unemployed, was not paid full salary or during which a payment was delayed. The second variable (see column 2), is a so-called destitution scale, constructed on the basis of several responses to more specific questions in order to reflect the frequency with which a person or her family had to live without food, heating, electricity or clothes. ${ }^{23}$ Consistent with a priori expectations and previous literature, both variables have negative signs in both tables. This suggests that the more intense the economic hardship experienced by an individual, the lower is her support for the transition process. Note also that the young cohort dummy becomes insignificant.

Regarding the speed of reforms, respondents were asked in 1995 and 1996 whether they thought that the reform process was going "too fast", "too slow" or "at the right speed". The results in column (3) of Tables 8 and 9 indicate that the perceptions of a "wrong" speed of reforms ("too high" or "too slow") negatively influence individual attitudes towards transition. Interestingly, conducting reforms too fast

\footnotetext{
${ }^{23}$ This variable was already available in the dataset.
} 
may be associated with a stronger individual resistance, as suggested by the larger coefficient on the "too fast" dummy. In this case the young cohort dummy also becomes insignificant.

Individual preferences about the political system may be another potentially omitted variable, especially in the equation for political reforms. We attempt to proxy for a preference towards dictatorship, using the following two variables. Survey respondents were asked whether they would approve if the Parliament was suspended and whether it would be better "to get rid of Parliament and elections and have a strong leader". The results in columns (4) and (5) indicate that such preferences are indeed significantly and negatively correlated to support for transition, both in the economic and in the political dimensions.

We then attempt to control for the extent of corruption in a country by generating a variable that equals 1 if an individual thinks that most or almost all "public officials are engaged in bribe-taking and corruption" in his country, and equals zero if he thinks that "very few" or "less than half public officials are corrupt". Unfortunately, this question was asked only in 2001 and 2004 and the sample size drops substantially. Nevertheless, as indicated in column (6), the coefficients on the other individual characteristics remain fairly robust, while the corruption variable is significant and has the expected negative sign for both economic and political attitudes.

The opinion that the state should engage more actively in redistributing resources across individuals may originate either as a cultural preference or as a reaction to current unfavorable economic circumstances. In any case, preferences towards redistribution may be correlated with individual attitudes towards transition from communism. This is indeed the case, as is shown in column (7). Those who agree with the statement that "incomes should be made more equal so there is no big difference in income" (as opposed to the statement "Individual achievement should determine how much people are paid") have less support for transition.

In this empirical literature, age is often used as a proxy for ideology. However, age could reflect either the increased hardship imposed by transition on older individuals with obsolete skills, or, indeed, the fact that their ideological values might have been shaped by communist institutions and culture. In fact, as we have shown, older individuals are particularly negative about the transition process and are significantly more likely to belong to the "nostalgic" and "reactionary" groups. In addition, in column (8), we include a variable which indicates whether the respondent or any of his family members was formerly a member of the Communist Party. As expected, this variable is significant and has a negative sign in both tables, suggesting that past party membership is negatively correlated with individual support for transition. At the same time, the significance of the age dummies is reduced and the young cohort dummy becomes insignificant, which suggests that, indeed, age is also - but not only - a proxy for ideology.

Finally, we have introduced several variables that measure the diffusion of trust towards political institutions and people (columns 9-12). Our findings suggest that trust towards parties, parliament, the president or other people is associated with a more positive assessment of the transition process (although trusting people is only marginally significant in the model for economic support).

Overall, throughout this exercise, the sign and significance of other individual characteristics remain fairly robust to the introduction of additional variables and to the related changes in the composition and size of the sample. Although this exercise is purely descriptive, it sheds additional light on the issue of who is against transitional reforms. It is also in line with the "lifetime learning model" of regime support (Mishler 
and Rose, 2002), which implies that citizens learn about a new regime on the basis of individual experiences, characteristics and preferences.

\section{c. Country-specific analysis}

In this section, we take a closer look at cross-country differences. As shown in the previous sections, significant country dummies suggest that there are differences across countries in support for transition. In addition, since the composition of the countries' sample changes throughout the period, one would need to undertake a country-specific analysis in order to identify trends in support attitudes. This section provides such an analysis and examines the determinants of individual evaluations of the economic and the political systems in fourteen transition countries on a country-by-country basis (Tables 10 and 11 , respectively).

The individual characteristics included in the regressions are the same as in the baseline model in Tables 3 and 4. The only exception is the introduction of a minority dummy for the Baltic States. Ethnic minorities constitute a significant part of the population in these countries (especially in Estonia and Latvia) and the process of transition may have affected them differently from the majority of population. ${ }^{24}$

\section{[Insert Table 10 and Table 11]}

An analysis of the attitudes towards transition on a country-by-country basis reveals that there is indeed some heterogeneity across countries. Regarding the economic transition (Table 10), age has a negative correlation with the dependent variable in all countries, except for Slovenia, Romania and Croatia. In addition, belonging to the young cohort has a positive effect in Bulgaria and a larger one in Russia. Being female has a significant negative effect in seven countries, with the strongest negative effect in the three Baltic States. University education is strongly associated with support for transition in all countries, except for Romania, Croatia and Belarus. Urbanization has, in general, a positive and significant effect in most countries, with the exception of Slovenia, Romania, Croatia, Ukraine and Belarus. Being in the highest household income quartiles always has a positive and significant correlation with support attitudes, apart for Croatia. Belonging to an ethnic minority has a significant negative effect in all three Baltic countries, with the largest effect being in Estonia, probably reflecting the hardship of adjusting to the new system for individuals of Russian origin and their dissatisfaction with their economic situation and political rights. It is remarkable that individual unemployment does not appear to be significant in Russia and Belarus. This could presumably be related to the fact that wage arrears rather than layoffs have been prevailing in Russia as a means to reduce the burden of labor costs on firms, and that very few reforms have taken place in Belarus at all. Regarding the evolution of support over time, there is an increasing trend in a slight majority of countries as support was in general lower in the 1990s than in $2004 .^{25}$

As regards support attitudes towards the political transition (see Table 11), age has a negative effect in all countries, at least for some age groups, except for Latvia and Croatia, and the effect is only marginally

24 For an analysis of labor market performance of immigrants and non-citizens in the new EU member states see Kahanec and Zaiceva (2009).

${ }^{25}$ Note that for Croatia we have information only for 1992 and 1993, with the latter being the reference year. 
significant (at the 10 percent level) for some groups in Hungary and Lithuania. Belonging to the young cohort has a positive and significant correlation with the support attitudes only in Estonia, Lithuania and Croatia. Being female has a significantly negative effect again in about half of the countries, including Poland, Slovenia, the Baltic States and Bulgaria. University education has a positive association everywhere, except for Croatia and Belarus. Living in a city generally has a positive and significant effect, except for Croatia, Romania and Belarus, while it is negative in the Ukraine. Belonging to the highest household income quartile always has a positive and significant impact (with the exception of Croatia where it is insignificant). The minority dummy for the Baltic countries is again negative and significant with the largest effect being in Estonia. Regarding the unemployment status, our results suggest that it is much less important for the evaluation of the political system than of the economic system, since this variable is significant only for Latvia, Bulgaria and Croatia (and marginally significant for Hungary and Lithuania). Finally, regarding year dummies, while the support for economic transition is generally increasing in roughly half of the countries, there is less evidence of an increasing trend in the support for the political transition, as the coefficients on the year dummies are positive or insignificant in many cases. If anything, countries where support for change in the political system was lower in the 1990s than in 2004 include the CIS, Lithuania and, to some extent, Hungary.

Overall, the country-specific analysis shows that, although there is some heterogeneity across countries, differences are in many cases related to the size and significance of the estimated coefficients. Moreover, individual characteristics, such as age, university education, urbanization, employment status and relative income, almost always have, with a few exceptions, a significant effect on individual assessments of both the economic and the political systems. The support attitudes seem to increase mostly for the economic transition, while there is less evidence of an increasing trend for the political support. Although support seems to have risen in the CIS countries by 2004, they have on average the lowest support attitudes as suggested by the coefficients on country-specific dummies in the previous sections. Thus, in what follows, we return to the pooled analysis and will search for potential explanations for the lower level of support that apparently characterizes the CIS countries.

\section{Why is support for transition lower in the $\mathrm{CIS}$ countries?}

A common finding from the previous sections is that the average level of support for transition, in both the economic and political dimensions, differs across countries, with the lowest support being in the CIS countries. In fact, given the diversity of the initial conditions, of the objectives and sequences of the reforms that have been adopted, of the forms and degrees of political developments and of the economic performance achieved, it would be surprising if citizens from different countries would converge to the same evaluations of their countries' experiences.

Both $\mathrm{CIS}$ and CEE countries have the experience of a socialist economy with relatively secure jobs, officially low inequality and equal pay, but also low motivation and low individual responsibility. There were, however, several important differences between these countries, including differences in their history and overall democratic achievements. Even in 2004, the Freedom House Ranking of political rights and civil liberties ranged between "not free" in Belarus and "partly free" in Russia and Ukraine to "free" in the CEE countries. CIS countries have arguably gone through a longer and more intense experience of communism and of the socialist economy relative to most CEE countries. Communism was the national form of government in Russia, Belarus and Ukraine, and the period under communism lasted seven 
decades in the CIS, five decades in the Baltic States and four decades in the CEE countries. In addition, many central and eastern European countries had historical and geographic ties to western Europe, including trade relations (Svejnar, 2002). Also, the economic reforms were implemented using different strategies and policies, and as a result the performance of the CIS and CEE countries differed. As mentioned in the introduction, the potential explanations for these differences in performance suggested in the literature include larger safety nets and non-employment benefits in the CEE countries, better legal systems and enforcement of laws and regulations, a lower degree of corruption and rent seeking than in the $\mathrm{CIS}$. On the basis of this literature, this section explores several potential explanations for the differences in support attitudes between CIS and CEE countries.

Which factors may account for these differences? Do individual transition-related experiences and preferences contribute to explain them, or do differences across countries in economic performance and institutions matter? In this section, we present our explorations of these questions and suggest a (nonexhaustive) list of several potential explanations. The role of individual experiences and preferences is examined in section $6 \mathrm{a}$, and that of country-specific factors in section $6 \mathrm{~b}$.

\section{a. Individual experiences, values and preferences}

In order to examine to what extent the lower support in the CIS countries may be attributable to individual experiences, values and preferences, we add to our baseline model (see Tables 3 and 4 , column (3)) additional interaction terms with country dummies and individual variables. If these variables contribute to explain the lower levels of support in the CIS countries, we should observe a significant coefficient on these additional interactions and at the same time the coefficients on the Russia, Ukraine and Belarus dummies should either decrease in magnitude or become insignificant. On the basis of the literature mentioned above, the candidates for potential explanations in our dataset include preferences for redistribution and income equality, for state responsibility over individuals' material security and for state ownership, as well as for a secure (but also less rewarding) job. In addition, we have experimented with the variables already used in Tables 8 and 9, such as transition-related hardship, opinions on the speed of reforms and on corruption, preferences for a strong leader and trust in political institutions.

\section{[Insert Table 12]}

Table 12 shows the estimation results for both economic (upper panel) and political (lower panel) support attitudes. ${ }^{26}$ Since the results are qualitatively the same in both panels, we will discuss them jointly in what follows. This table indicates that trusting political institutions (parties and parliament, but not the president) and having preferences for state responsibility and ownership contribute to a greater or smaller extent to explaining the lower support attitudes in the CIS, as the coefficients on the dummies for Russia, Ukraine and Belarus diminish in absolute value, while the additional interaction terms are significant. Remarkably, another variable that contributes greatly to explain these differences is individual preference for a secure job and low pay (as opposed to high-pay job and high risks), suggesting that employment-related reasons are indeed important. On the other hand, contrary to what was expected,

\footnotetext{
${ }^{26}$ The rest of the individual characteristics is the same as in the baseline model in Tables 3 and 4. In Table 12, results in each odd-numbered column should be compared with those in the adjacent even-numbered column with the same sample size.
} 
preferences for equal income do not explain the lower support attitudes in the CIS countries (if anything, only marginally in Russia).

Regarding other variables (not reported, but available upon request), there is no conclusive evidence that transition-related hardship matters for explaining the differences between the $\mathrm{CIS}$ and other countries. While the variable based on the destitution scale explains some part of this difference, as suggested by the decreased coefficients on the CIS country dummies, the number of weeks without pay or job does not contribute to explaining these differences. These results, however, may be interesting per se, suggesting that it is the number of weeks without food and heating that matters, rather than the number of weeks without pay or job. Indeed, this seems plausible if we take into account the peculiarities of transition processes in these two regions, in particular, labor hoarding and high wage arrears in Russia. There is also evidence that the speed of the reforms matters to some extent, with the "too fast" variable explaining a small part of the differences in Russia and "too slow" in Belarus (where indeed very few if any reforms took place) and Ukraine (where dissatisfaction with the corrupted government and sluggish transformation has resulted in the Orange Revolution in late 2004). Having preferences for a dictatorship and approving a strong leader seems to reduce to some extent the magnitude of the coefficients for Russia and Ukraine, but not for Belarus (where the interaction is insignificant). In contrast, individual perceptions of corruption do not explain the lower support in the CIS countries (although the sample size becomes small).

Overall, trust in political institutions, preferences for a greater role of the state in the economy, and, especially, preferences for secure (and less remunerated) jobs matter in explaining part of the differences between the $\mathrm{CIS}$ and other countries. However, although the coefficients on the CIS dummies are diminished in size, they have not become insignificant after the inclusion of these additional interaction terms. This suggests that there are other important factors that should be explored further.

\section{b. Country-specific performance and institutions}

To complete the picture, we now focus on macro-economic and institutional indicators of the overall quality of the economic and political systems. The role of institutions and policies in affecting individual attitudes in post-communist countries has been documented in the literature (see, among others, Denisova et al., 2007; Guriev and Zhuravskaya, 2009). For example, output growth and lower income inequality as well as less corruption or better governance could signal better opportunities for most individuals and could thus be associated with more support for transition. On the other hand, as argued in Rodrik (1995) and Fidrmuc (1999), especially at the beginning of transition, high unemployment may actually signal the need for more radical reforms and thus paradoxically reinforce support for reforms. Therefore, the sign on the unemployment variable is a priori ambiguous.

Again, we focus on how the introduction of these new variables into the baseline model affects the coefficients of the country dummies. Results are reported in Tables 13 and 14 for the economic and political systems, respectively.

[ Insert Table 13 and Table 14]

In order to facilitate comparisons, column (1) reproduces the results from Tables 3 and 4 (column 3 ). Individual controls are included in all regressions, but are not reported to save space. Column (2) 
introduces three traditional macro-economic control variables, aggregate unemployment, GDP per capita and inflation, as well as a political indicator for the extent of democracy in a country, the Democracy Index from the Polity IV database. As can be seen from this column, none of the macro-economic variables is statistically significant (note, however, that they are included in addition to country and yearspecific effects). ${ }^{27}$ This may be due to several reasons. First, individuals may care more about their own economic performance (i.e. unemployment) than about unemployment in their country in general. ${ }^{28} \mathrm{~A}$ second reason may be that left-wing and right-wing individuals might place different weights on unemployment vs. inflation. ${ }^{29}$ As argued by Di Tella and MacCulloch (2005), consistent with "partisan" models of political economy, left-wing individuals care more about unemployment relative to inflation than right-wingers. When averaging across left and right-wing individuals (as is done here), these differences may cancel out. Third, high unemployment might actually signal the need for more reforms (as in Rodrik, 1995). Finally, an indicator for the overall progress in transition could constitute an omitted variable. Hence, in column (3) we control for the lagged EBRD index of transition reforms. The introduction of these regressors definitely raises issues of collinearity and endogeneity, hence caution is needed when interpreting these results. In any case, the reforms index is either only marginally significant or insignificant and, if anything, a higher unemployment rate is negatively correlated with support for economic transition, but is unrelated with support for political transition.

Somewhat surprisingly, the higher level of democracy is negatively related to support for transition (in both Tables). To interpret this result, note that, for the majority of countries, this indicator does not vary much during this period, with the exception of Romania (where it is increasing) and Belarus (where it is decreasing). Thus, this variable acts almost as a dummy, reflecting at most the difference between EU and non-EU members, and does not convey much additional information into the regressions. It is also in line with the results in Guriev and Zhuravskaya (2009), who find a negative relation between democracy and the happiness index, and also with Denisova et al. (2007), who show that, in more democratic countries, individuals who experience economic hardship during transition are more likely to favor renationalization.

An increase in income inequality may be another reason why people have negative attitudes towards the economic or the political system. In line with Guriev and Zhuravskaya (2009), we find that the Gini index has a significant negative effect in both Tables 13 and 14 . While its inclusion does not, in general, diminish the significance of the CIS dummies in Table 13, it does so in Table 14, suggesting that increased inequality might be an important explanation of the differences in individual support for the political system. ${ }^{30}$

\footnotetext{
${ }^{27}$ Macro-economic variables are also insignificant if an indicator for democracy is not added to the regressions. Note also that these country-specific variables may be collinear with country and year fixed effects

${ }^{28}$ This is consistent with the so-called "individualist" hypothesis from the political economy literature discussed in section 2.

${ }^{29}$ In addition, there might be a relevant discontinuity in the individual reactions to inflation, as many countries in our sample where characterized by hyperinflation in the early 1990s.

${ }^{30}$ To proxy for the deterioration of public goods we have experimented with several indicators, such as hospital beds, life expectancy, number of doctors, public expenditures on health and education, mortality rates of children, immunization rate and enrollment rates in primary, secondary and tertiary education. For instance, life expectancy, in particular of males, declined significantly in the CIS countries (Svejnar, 2002). However, the inclusion of these variables, in general, did not contribute to the disappearance of significant effects on the CIS country dummies, while the number of hospital beds and doctors reduced somewhat the magnitude of some country-specific effects (available upon request).
} 
Finally, to analyze whether the quality of political institutions matter, we include World Bank Governance Indicators (an average of all indicators in column 6 and all of them separately in column 7). The results should now be compared with column (5), where the baseline regressions are run for the same subsample with non-missing information on governance. The coefficient of the single governance index is positive (although insignificant). Notably, the inclusion of this indicator (either as a simple average of all indicators or in disaggregated form) eliminates the significance of all the negative CIS country dummies, in particular in the equation for the economic transition. ${ }^{31}$ This may suggest that the quality of political institutions matters in explaining the negative attitudes towards the functioning of a country's economic system. In addition, when included separately (column 7), the Governance Indicators have heterogeneous effects on economic and political attitudes. While political stability, regulatory quality and the rule of law are associated with higher support for the economic transition, it is political stability and the rule of law that matter for the evaluation of change in the political system, with the latter variable having the largest positive effect.

\section{Conclusions}

As the recent EBRD Life in Transition survey remarks, "17 years of transition have taken a toll" (EBRD, 2007b). Indeed, there is a certain "transition fatigue" in the region, a discontent with transition that could be also responsible for the more frequent changes of government in several countries in the recent years. In this paper we document the extent of this discontent in 14 transition countries during 1991-2004 and analyze its determinants.

We find that the overall support for change in both the economic and political systems is relatively low and heterogeneous across different interest groups and countries, although public support for political transition is higher than for the economic transition. The lower support is found, in line with the literature, among the older, less educated, unemployed and poor individuals and among females, that is those who were more likely to "lose" from transition in relative terms. Support for transition is lowest in the CIS countries. On the other hand, there is also an increasing trend in support for the economic transition in many countries. These main findings remain robust to changes in the specification and in the definition of the dependent variable. Interestingly, it appears that the same factors that are related to an "aversion to transition" (lower support) are also positively related to a willingness to return to communism. However, only one-third of individuals who evaluate the past socialist economy or communist system positively, would actually agree to do so.

We also find evidence that transition-related hardship, opinions on the speed of reforms, political preferences and preferences towards redistribution, ideology and social capital matter. Economic difficulties experienced during the transition, individual preferences towards dictatorship or redistribution of incomes, opinions on corruption, ex-Communist Party membership and less trust for politicians or other people are associated with lower support for the transition process. Interestingly, individuals who think that the reforms were conducted too fast are most likely to oppose the transition.

${ }^{31}$ Note that in the equation for the political system (Table 14), the coefficients on CIS country dummies become insignificant already in the sub-sample with non-missing observations for the governance indicators (column (5)). 
Finally, exploring the potential explanations for the lower support attitudes in the CIS countries, we find evidence for the importance of trust in political institutions, preferences for a greater role of the state in the economy, and, especially, preferences for secure (and less remunerated) jobs. There is also evidence that macro-economic and political institutions matter. Unequal provision and the deterioration of public goods seem to matter to some extent for explaining the lower support for the economic transition. On the other hand, increased inequality is an important factor in explaining the lower support for the political transition. More importantly, the quality of political institutions, as measured by the Governance Indicators, contributes greatly to explaining the lower support for the economic transition in the CIS. In particular, while political stability, regulatory quality and the rule of law mostly affect the support for the economic transition, it is the rule of law that has the largest positive effect on the support for the political transition. 


\section{References}

Aghion, P. and Blanchard, O.-J. (1994). On the Speed of Transition in Central Europe. NBER Macroeconomics Annual: 283-319.

Alesina, A. and Fuchs-Schuendeln, N. (2007). Good Bye Lenin (Or Not?). The Effect of Communism on People's Preferences. American Economic Review 97: 1507-28.

Bertrand, M. and Mullainathan, S. (2001). Do People Mean What They Say? Implications for Subjective Survey Data. American Economic Review 91 (2): 67-72.

Blanchard, O.-J. (1997). Clarendon Lectures: The Economics of Transition in Eastern Europe. Oxford University Press, Oxford.

Blanchflower, D. G. (2001). Unemployment, Well-Being and Wage Curves in Eastern and Central Europe. Journal of the Japanese and International Economics 15: 364-402.

Blanchflower, D. G. and Freeman, R. B. (1997). The Attitudinal Legacy of Communist Labor Relations. Industrial and Labor Relations Review 50 (3): 438-59.

Boeri, T. (2000). Structural Change, Welfare Systems and Labor Reallocation. Oxford: Oxford University Press.

Boeri, T. and Terrell, K. (2002). Institutional Determinants of Labor Reallocation in Transition. Journal of Economic Perspectives 16 (1): 51-76.

Brainerd, E. (1998). Winners and Losers in Russia's Economic Transition. American Economic Review 88 (5): 1094-1116.

Campos N. and Coricelli, F. (2002) "Growth in Transition: What We Know, What We Don't, and What We Should" , Journal of Economic Literature, XL, September, pp.793-836.

Denisova, I., Eller, M., Frye, T. and Zhuravskaya, E. (2007). Who Wants to Revise Privatization and Why? Evidence from 28 Post-Communist Countries. CEPR Discussion Paper No. 6603.

Di Tella, R. and MacCulloch, R. (2005). Partisan Social Happiness. Review of Economic Studies 72 (2): 367-93.

Doyle, O. and Fidrmuc J. (2006). Who is in Favour of Enlargement? Determinants of Support for EU Membership in Candidate Countries' Referenda. European J ournal of Political Economy 22: 520-43.

Doyle, O. and Fidrmuc, J. (2003). Anatomy of Voting Behavior and Attitudes During Post-Communist Transition: Czech Republic 1990-1998. In Campos, N. and Fidrmuc, J. (eds.) Political Economy of Transition and Development: Institutions, Politics and Policies. In ZEI Studies in European Economics and Law, Kluwer Academic, Boston, Ch. 7: 139-64.

Earle, J.S. and Gehlbach, S. (2003). A Spoonful of Sugar: Privatization and Popular Support for Reform in the Czech Republic. Economics and Politics 15 (1): 1-32.

Easterlin, R. A. (2008). Lost in Transition: Life Satisfaction on the Road to Capitalism. IZA Discussion Paper No. 3409.

Eble, S. and Koeva, P. (2002). What Determines Individual Preferences over Reform? Microeconomic Evidence from Russia. IMF Staff Papers 49, Special Issue: 87-110.

EBRD (2007a). Transition Report: People in Transition. European Bank for Reconstruction and Development, London, UK.

EBRD (2007b). Life in Transition. European Bank for Reconstruction and Development, London, UK. (http://www.ebrd.com/pubs/econo/lit.htm)

Fernandez, R. and Rodrik, D. (1991). Resistance to Reform. Status Quo Bias in the Presence of Individual-Specific Uncertainty. American Economic Review 81: 1146-55.

Fidrmuc, J. (1999). Unemployment and the Dynamics of Political Support for Economic Reforms. Journal of Policy Reform 3: 139-59

Fidrmuc, J. (2000). Political Support for Reforms: Economics of Voting in Transition Countries. European Economic Review 44: 1491-1513.

Guriev, S. and Zhuravskaya, E. (2009). (Un)Happiness in Transition. Journal of Economic Perspectives (forthcoming).

Hayo, B. (2004). Public Support for Creating a Market Economy in Eastern Europe. Journal of Comparative Economics 32: 720-44. 
Jackson, J. E., Klich, J. and Poznańska, K. (2003). Economic Transition and Elections in Poland. Economics of Transition 11 (1): 41-66.

Kahanec, M. and Zaiceva, A. (2009). Labor Market Outcomes of Immigrants and Non-Citizens in the EU: An East-West Comparison. International J ournal of Manpower 30 (1+2): 97-115.

Kornai, J. (2006). The great transformation of Central Eastern Europe: Success and disappointment. Economics of Transition, 14(2): 207-244.

Krastev, I. (2007). The Strange Death of the Liberal Consensus, J ournal of Democracy, 18(4): 5663.

Kim, B-Y. and Pirttilä, J. (2006). Political Constraints and Economic Reform: Empirical Evidence from the Post-Communist Transition in the 1900s. Journal of Comparative Economics 34: 446-66.

Landier, A., Thesmar, D. and Thoenig, M. (2008). Investigating Capitalism Aversion. Econmic Policy, July: 465-97.

Lazar, O., Mishler, W., and Rose, R. (2007.) What is the Effect of Globalization on Support for Market Economies in Post-Communist Europe? University of Aberdeen, Centre for the Study of Public Policy, Studies in Public Policy No. 421.

Lin, J.Y., Cai, F., and Li, Z. (2002). The Lessons of China's Transition to a Market Economy. Cato Journal, 16(2).

Linz, S.J. and Semykina, A. (2008). How Do Workers Fare During Transition? Perceptions of Job Insecurity Among Russian Workers, 1995-2004. Labour Economics 15: 442-58.

Mayda, A.M. (2006). Who Is Against Immigration? A Cross-Country Investigation of Individual Attitudes toward Immigrants. Review of Economics and Statistics 88 (3): 510-30.

McMillan, J - Havrylyshyn, O. (2004) Reform: What Pace Works. Finance and Development, September, 34-41.

Milanovic, B. and Ersado, L. (2008). Reform and Inequality during the Transition: An Analysis Using Panel Household Survey Data, 1990-2005. World Bank Policy Research Working Papers no. 4780.

Mishler, W. and Rose, R. (2000a). Political Support for Incomplete Democracies: Realist vs. Idealist Theories and Measures. University of Aberdeen, Centre for the Study of Public Policy, Studies in Public Policy No. 333.

Mishler, W. and Rose, R. (2000b). Regime Support in Non-Democratic and Democratic Contexts. University of Aberdeen, Centre for the Study of Public Policy, Studies in Public Policy No. 336.

Mishler, W. and Rose, R. (2002). Learning and Re-Learning Regime Support: The Dynamics of PostCommunist Regimes. European Journal of Political Research 41: 5-36.

Mishler, W. and Rose, R. (2008). A Two-Way Street in Popular Support for New Regimes: The Political Economy of Post-Communist Transitions. University of Aberdeen, Centre for the Study of Public Policy, Studies in Public Policy No. 441.

Murphy, K., Schleifer, A. and Vishny, R. (1992). The Transition to a Market Economy: Pitfall of Partial Reform. Quarterly Journal of Economics 107(3) (August): 889-906.

Opper, S. (2004). The Political Economy of Privatization: Empirical Evidence from Transition Economies. KYKLOS 57: 559-86.

Rodrik, D. (1995) The Dynamics of Political Support for Reforms in Economies in Transition. Journal of Japanese and International Economics 9: 403-25.

Roland, G. (2002) The Political Economy of Transition. Journal of Economic Perspectives, 16(1): 29-50.

Rose, R. (2007). Learning to Support New Regimes in Europe. University of Aberdeen, Centre for the Study of Public Policy, Studies in Public Policy No. 424.

Rupnik, J. (2008). From Democracy Fatigue to Populist Backlash, Journal of Democracy, 18(4): 1725.

Sanfey, P. and Teksoz, U. (2007). Does Transition Make You Happy? Economics of Transition 15 (4): 707-31.

Scheve, K. F. and Slaughter, M. J. (2001). Labor Market Competition and Individual Preferences ver Immigration Policy. Review of Economics and Statistics, 83: 133-45.

Svejnar, J. (2002). Transition Economies: Performance and Challenges. Journal of Economic Perspectives 16 (1): 3-28. 
Terrell, K. (1999). Worker Mobility and Transition to a Market Economy: Winners and Losers, in: New Markets, New Opportunities? Economic and Social Mobility in a Changing World. Nancy Birdsall and Carol Graham (eds.), Washington DC, Brookings Institution, Ch. 7.

Tucker, J . (2002). The First Decade of Post-Communist Elections and Voting: What Have We Studied, and How Have We Studied It? Annual Review of Political Science 5: 271-304.

Valev, N. (2004). No Pain, No Gain: Market Reform, Unemployment, and Politics in Bulgaria. Journal of Comparative Economics 32: 409-25. 
Figure 1: Evaluations of the economic and political systems in 1993 and 2004

Economic System

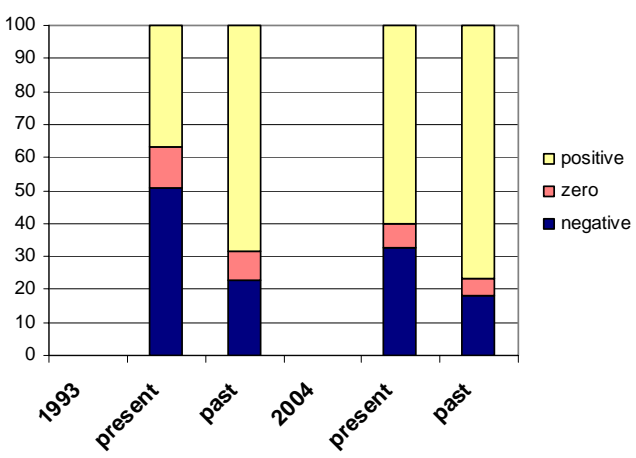

Political System

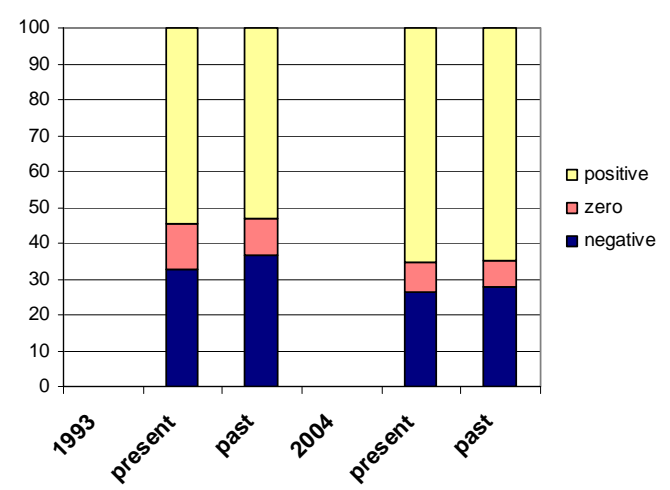

Source: Authors' tabulations from the New Barometers data. Sample includes all individuals.

Figure 2: Dynamics of Support, 1991-2004

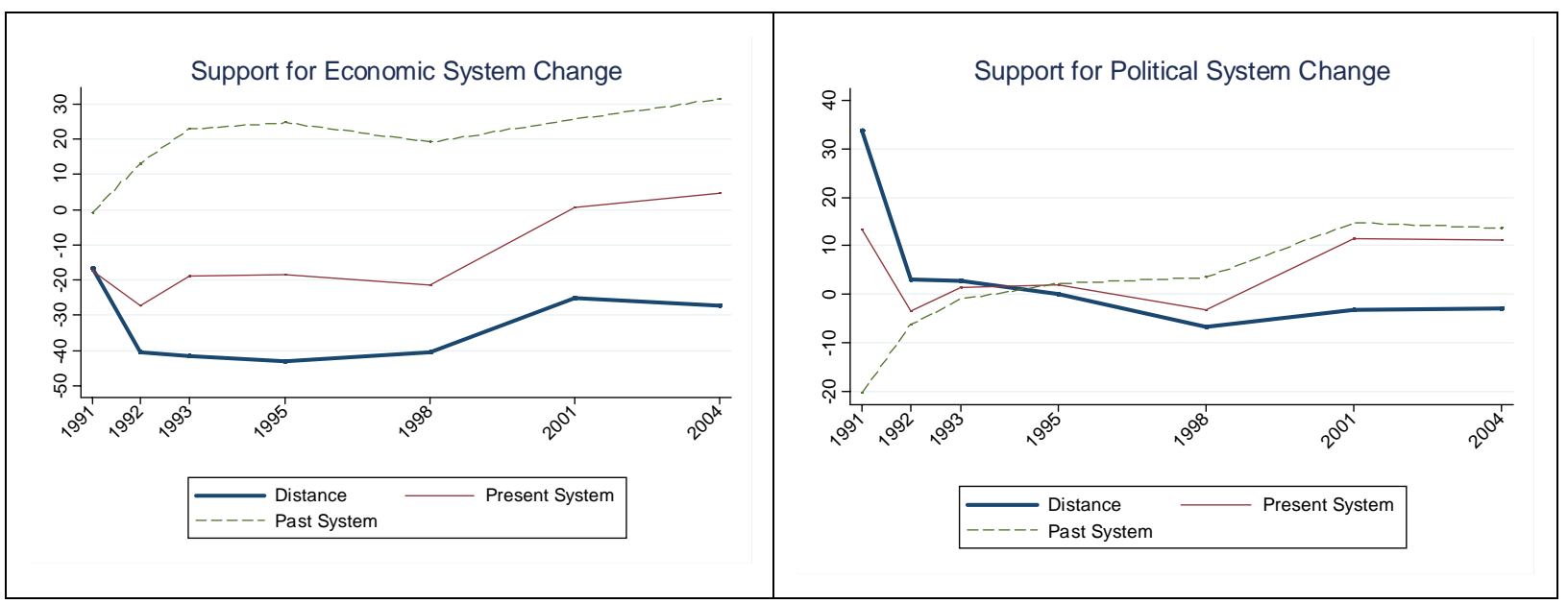

Source: Authors' tabulations from the New Barometers data. See text and Appendix for definition of distance.

Notes: 1996 and 2000 are excluded, since only Russia and the Baltic States are available for these years. Sample includes all individuals. 
Figure 3: Support for change in the economic and political systems, by country

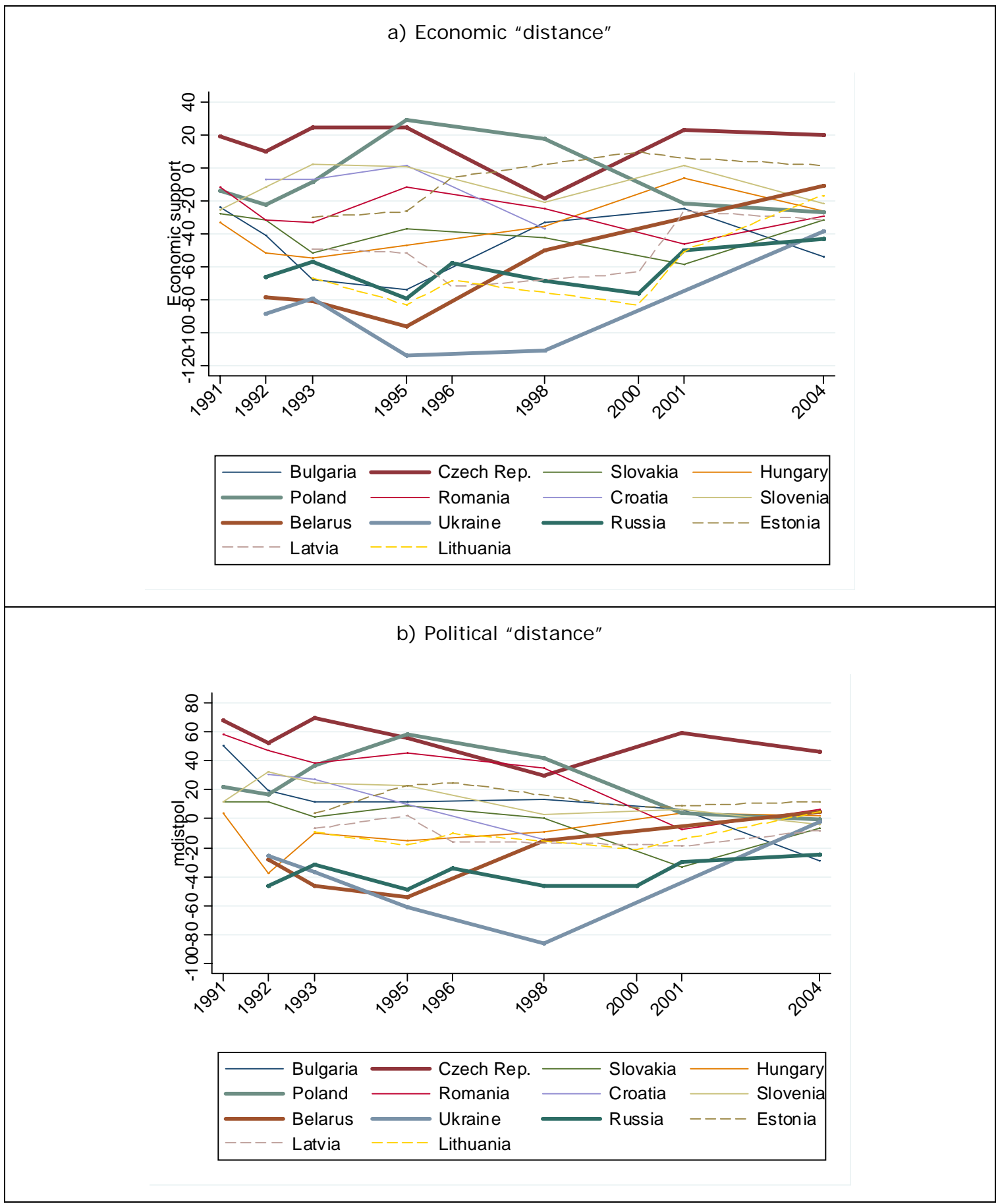

Source: Authors' tabulations from the New Barometers data. Notes: See text and Appendix for definition of distance. Sample includes all individuals. 
Figure 4: Support for economic transition by relative family economic situation

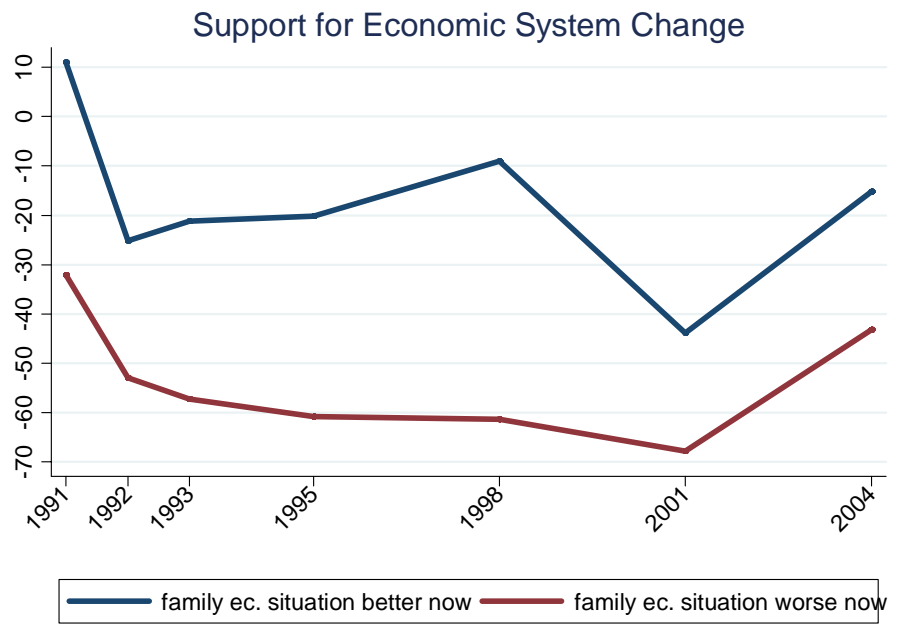

Source: Authors' tabulations from the New Barometers data. Sample includes all individuals. 
Table 1a: Groups formed on the basis of the evaluation of the economic or political system

\begin{tabular}{|c|c|c|c|}
\hline Past & Present & $\begin{array}{c}\text { Economic } \\
\text { system }\end{array}$ & $\begin{array}{l}\text { Political } \\
\text { system }\end{array}$ \\
\hline Positive & Positive & Positive & Compliant \\
\hline Negative & Negative & & \\
\hline Negative & Neutral & & \\
\hline Neutral & Negative & & \\
\hline Neutral & Neutral & Negative & Skeptic \\
\hline Positive & Neutral & & \\
\hline Positive & Negative & Nostalgic & Reactionary \\
\hline Neutral & Positive & & \\
\hline Negative & Positive & Pro-market & Democrat \\
\hline
\end{tabular}

Table 1b: Classification of countries into groups according to the evaluation of the economic and political systems

\begin{tabular}{|c|c|c|c|}
\hline & & Economic System & Political System \\
\hline \multirow[t]{2}{*}{ Czech R. } & 1991 & Pro-mkt & Democrat \\
\hline & 2004 & Pro-mkt & Democrat \\
\hline \multirow[t]{2}{*}{ Slovakia } & 1991 & Nostalgic & Democrat \\
\hline & 2004 & Nostalgic & Reactionary \\
\hline \multirow[t]{2}{*}{ Hungary } & 1991 & Nostalgic & Compliant \\
\hline & 2004 & Nostalgic & Compliant \\
\hline \multirow[t]{2}{*}{ Poland } & 1991 & Negative & Skeptic \\
\hline & 2004 & Nostalgic & Skeptic/Comp \\
\hline \multirow[t]{2}{*}{ Slovenia } & 1991 & Negative & Democrat \\
\hline & 2004 & Positive & Compliant \\
\hline \multirow[t]{2}{*}{ Estonia } & 1993 & Nostalgic & Compliant \\
\hline & 2004 & Positive & Compliant \\
\hline \multirow[t]{2}{*}{ Latvia } & 1993 & Nostalgic & Reactionary \\
\hline & 2004 & Nostalgic & Reactionary \\
\hline \multirow[t]{2}{*}{ Lithuania } & 1993 & Nostalgic & Reactionary \\
\hline & 2004 & Positive & Compliant \\
\hline \multirow[t]{2}{*}{ Bulgaria } & 1991 & Nostalgic & Democrat \\
\hline & 2004 & Nostalgic & Reactionary \\
\hline \multirow[t]{2}{*}{ Romania } & 1991 & Negative & Democrat \\
\hline & 2004 & Nostalgic & Democrat \\
\hline \multirow[t]{2}{*}{ Croatia } & 1992 & Negative & Skeptic \\
\hline & 1998 & Nostalgic & Skeptic \\
\hline \multirow[t]{2}{*}{ Russia } & 1992 & Nostalgic & Reactionary \\
\hline & 2004 & Nostalgic & Compliant \\
\hline \multirow[t]{2}{*}{ Ukraine } & 1992 & Nostalgic & Reactionary \\
\hline & 2004 & Positive & Compliant \\
\hline \multirow[t]{2}{*}{ Belarus } & 1991 & Nostalgic & Reactionary \\
\hline & 2004 & Positive & Compliant \\
\hline
\end{tabular}

Notes: Based on average responses by country, using classification from Table 1a. 
Table 2: Group linkages for the evaluations of the economic and political systems

\begin{tabular}{|c|c|c|c|c|c|}
\hline \multicolumn{3}{|c|}{ Economic system } & \multicolumn{3}{|c|}{ Political system } \\
\hline All & Reactionary & Democrat & All & Nostalgic & Pro-market \\
\hline \multicolumn{6}{|c|}{1993} \\
\hline Nostalgic & Nostalgic & Nostalgic & Reactionary & Reactionary & Reactionary \\
\hline 47.14 & $\begin{array}{l}82.76 \\
\text { Negative }\end{array}$ & $\begin{array}{l}24.75 \\
\text { Negative }\end{array}$ & $\begin{array}{c}26.91 \\
\text { Skeptic }\end{array}$ & 47.87 & 3.27 \\
\hline $\begin{array}{l}21.32 \\
21\end{array}$ & $\begin{array}{l}\text { Negative } \\
7.58\end{array}$ & $\begin{array}{l}\text { Negative } \\
23.01\end{array}$ & $\begin{array}{c}\text { Skeptic } \\
24.26\end{array}$ & $\begin{array}{l}\text { Skeptic } \\
1871\end{array}$ & Skeptic \\
\hline Positive & Positive & Positive & Compliant & Compliant & Compliant \\
\hline 18.99 & 8.09 & 16.51 & 21.45 & 18.87 & 5.95 \\
\hline Pro-market & Pro-market & Pro-market & Democrat & Democrat & Democrat \\
\hline 12.55 & 1.57 & 35.73 & 27.37 & 14.55 & 75.85 \\
\hline \multicolumn{6}{|c|}{2004} \\
\hline Nostalgic & Nostalgic & Nostalgic & Reactionary & Reactionary & Reactionary \\
\hline 33.79 & 73.57 & 14.11 & 25.01 & 55.52 & 3.58 \\
\hline Negative & Negative & Negative & Skeptic & Skeptic & Skeptic \\
\hline 9.39 & 5.12 & 9.93 & 13.44 & 12.12 & 13.30 \\
\hline Positive & Positive & Positive & Compliant & Compliant & Compliant \\
\hline 40.54 & 18.97 & 30.43 & 35.06 & 21.23 & 10.42 \\
\hline Pro-market & Pro-market & Pro-market & Democrat & Democrat & Democrat \\
\hline \multirow{2}{*}{\multicolumn{6}{|c|}{ Average (all years) }} \\
\hline & & & & & \\
\hline Nostalgic & Nostalgic & Nostalgic & Reactionary & Reactionary & Reactionary \\
\hline 42.87 & 80.66 & 19.90 & 27.52 & 52.33 & 3.32 \\
\hline Negative & Negative & Negative & Skeptic & Skeptic & Skeptic \\
\hline 19.18 & 7.21 & 20.51 & 21.50 & 16.30 & 14.00 \\
\hline Positive & Positive & Positive & Compliant & Compliant & Compliant \\
\hline 23.85 & 10.40 & 19.59 & 24.26 & 18.88 & 8.27 \\
\hline Pro-market & Pro-market & Pro-market & Democrat & Democrat & Democrat \\
\hline 14.11 & 1.73 & 40.01 & 26.72 & 12.49 & 74.41 \\
\hline
\end{tabular}

Notes:

Col. 1-3: Evaluation of the economic system, for citizens which have expressed different evaluations of the political system (percent of total evaluations, all countries).

Col. 4-6: Evaluation of the political system, for citizens which have expressed different evaluations of the economic system (percent of total evaluations, all countries). 
Table 3: Determinants of support for the economic system: Present versus past

\begin{tabular}{|c|c|c|c|c|c|c|}
\hline & $\begin{array}{l}1) \\
\text { Past }\end{array}$ & $\begin{array}{c}(2) \\
\text { Present }\end{array}$ & $\begin{array}{c}(3) \\
\text { Distance }\end{array}$ & $\begin{array}{c}(4) \\
\text { Distance }\end{array}$ & $\begin{array}{c}(5) \\
\text { Distance if } \\
\text { pro- } \\
\text { market }=1 \text { or } \\
\text { nostalgic }=1\end{array}$ & $\begin{array}{c}\text { (6) } \\
\text { Distance if } \\
\text { pro- } \\
\text { market }=1\end{array}$ \\
\hline Female & $\begin{array}{c}0.092 * * * \\
(0.030)\end{array}$ & $\begin{array}{l}-0.098^{*} \\
(0.046)\end{array}$ & $\begin{array}{c}-0.127^{* *} \\
(0.048)\end{array}$ & $\begin{array}{c}-0.132 * * \\
(0.048)\end{array}$ & $\begin{array}{c}-0.152 * * \\
(0.055)\end{array}$ & $\begin{array}{c}0.012 \\
(0.013)\end{array}$ \\
\hline Young_cohort & $\begin{array}{c}-0.048 * * * \\
(0.013)\end{array}$ & $\begin{array}{c}0.111 * * * \\
(0.025)\end{array}$ & $\begin{array}{c}0.093 * * * \\
(0.019)\end{array}$ & $\begin{array}{c}0.082 * * * \\
(0.023)\end{array}$ & $\begin{array}{c}0.138 * * * \\
(0.042)\end{array}$ & $\begin{array}{l}-0.020 \\
(0.029)\end{array}$ \\
\hline Age $30-39$ & $\begin{array}{l}0.025^{*} \\
(0.014)\end{array}$ & $\begin{array}{c}-0.043 * * \\
(0.019)\end{array}$ & $\begin{array}{c}-0.047^{* *} \\
(0.016)\end{array}$ & $\begin{array}{c}-0.044 * * \\
(0.017)\end{array}$ & $\begin{array}{c}-0.057 * * \\
(0.023)\end{array}$ & $\begin{array}{c}0.003 \\
(0.020)\end{array}$ \\
\hline Age $40-49$ & $\begin{array}{c}0.123 * * * \\
(0.018)\end{array}$ & $\begin{array}{c}-0.090 * * * \\
(0.027)\end{array}$ & $\begin{array}{c}-0.145 * * * \\
(0.024)\end{array}$ & $\begin{array}{c}-0.152 * * * \\
(0.024)\end{array}$ & $\begin{array}{c}-0.177 * * * \\
(0.043)\end{array}$ & $\begin{array}{c}0.014 \\
(0.029)\end{array}$ \\
\hline Age $50-59$ & $\begin{array}{c}0.154 * * * \\
(0.022)\end{array}$ & $\begin{array}{c}-0.097 * * * \\
(0.025)\end{array}$ & $\begin{array}{c}-0.170 * * * \\
(0.026)\end{array}$ & $\begin{array}{c}-0.169 * * * \\
(0.026)\end{array}$ & $\begin{array}{c}-0.199 * * * \\
(0.037)\end{array}$ & $\begin{array}{c}0.019 \\
(0.026)\end{array}$ \\
\hline Age $>60$ & $\begin{array}{c}0.102 * * \\
(0.035)\end{array}$ & $\begin{array}{l}-0.052 \\
(0.047)\end{array}$ & $\begin{array}{c}-0.108 * \\
(0.050)\end{array}$ & $\begin{array}{c}-0.113^{* *} \\
(0.048)\end{array}$ & $\begin{array}{c}-0.132 * * \\
(0.059)\end{array}$ & $\begin{array}{c}0.024 \\
(0.048)\end{array}$ \\
\hline $\begin{array}{l}\text { Secondary / } \\
\text { vocational }\end{array}$ & $\begin{array}{c}-0.105 * * * \\
(0.025)\end{array}$ & $\begin{array}{c}0.033 \\
(0.025)\end{array}$ & $\begin{array}{c}0.094 * * * \\
(0.027)\end{array}$ & $\begin{array}{c}0.070 * * \\
(0.027)\end{array}$ & $\begin{array}{l}0.096 * * \\
(0.034)\end{array}$ & $\begin{array}{c}0.016 \\
(0.023)\end{array}$ \\
\hline University & $\begin{array}{c}-0.338 * * * \\
(0.021)\end{array}$ & $\begin{array}{c}0.108 * * * \\
(0.028)\end{array}$ & $\begin{array}{c}0.298 * * * \\
(0.025)\end{array}$ & $\begin{array}{c}0.266 * * * \\
(0.028)\end{array}$ & $\begin{array}{c}0.347 * * * \\
(0.040)\end{array}$ & $\begin{array}{c}0.019 \\
(0.036)\end{array}$ \\
\hline Single & $\begin{array}{c}-0.088 * * * \\
(0.019)\end{array}$ & $\begin{array}{c}0.010 \\
(0.015)\end{array}$ & $\begin{array}{c}0.067 * * * \\
(0.022)\end{array}$ & $\begin{array}{c}0.075 * * * \\
(0.019)\end{array}$ & $\begin{array}{c}0.092 * * * \\
(0.026)\end{array}$ & $\begin{array}{c}0.003 \\
(0.022)\end{array}$ \\
\hline $\begin{array}{l}\text { Divorced / } \\
\text { widowed }\end{array}$ & $\begin{array}{c}-0.013 \\
(0.015)\end{array}$ & $\begin{array}{c}-0.002 \\
(0.013)\end{array}$ & $\begin{array}{c}0.010 \\
(0.016)\end{array}$ & $\begin{array}{c}0.017 \\
(0.014)\end{array}$ & $\begin{array}{c}0.023 \\
(0.015)\end{array}$ & $\begin{array}{c}0.006 \\
(0.024)\end{array}$ \\
\hline City & $\begin{array}{c}-0.140 * * \\
(0.048)\end{array}$ & $\begin{array}{c}0.015 \\
(0.028)\end{array}$ & $\begin{array}{l}0.103 * * \\
(0.045)\end{array}$ & $\begin{array}{l}0.113 * * \\
(0.043)\end{array}$ & $\begin{array}{c}0.130 * * \\
(0.059)\end{array}$ & $\begin{array}{c}0.083^{* * *} \\
(0.015)\end{array}$ \\
\hline Big town & $\begin{array}{l}-0.022 \\
(0.026)\end{array}$ & $\begin{array}{l}-0.025 \\
(0.017)\end{array}$ & $\begin{array}{l}-0.002 \\
(0.024)\end{array}$ & $\begin{array}{c}0.011 \\
(0.022)\end{array}$ & $\begin{array}{c}0.012 \\
(0.028)\end{array}$ & $\begin{array}{c}0.033 \\
(0.019)\end{array}$ \\
\hline Unemployed & $\begin{array}{c}0.138 * * * \\
(0.032)\end{array}$ & $\begin{array}{c}-0.119 * * * \\
(0.028)\end{array}$ & $\begin{array}{c}-0.167 * * * \\
(0.036)\end{array}$ & $\begin{array}{c}-0.158 * * * \\
(0.032)\end{array}$ & $\begin{array}{c}-0.205^{* * * *} \\
(0.041)\end{array}$ & $\begin{array}{c}-0.022 \\
(0.021)\end{array}$ \\
\hline Pensioner & $\begin{array}{c}0.094 * * * \\
(0.019)\end{array}$ & $\begin{array}{l}-0.009 \\
(0.033)\end{array}$ & $\begin{array}{c}-0.067 * * \\
(0.031)\end{array}$ & $\begin{array}{c}-0.063^{*} \\
(0.029)\end{array}$ & $\begin{array}{l}-0.075 \\
(0.047)\end{array}$ & $\begin{array}{l}0.078 * * \\
(0.034)\end{array}$ \\
\hline $\begin{array}{l}\text { Student / } \\
\text { housewife }\end{array}$ & $\begin{array}{c}-0.064 * * * \\
(0.019)\end{array}$ & $\begin{array}{c}0.035^{* *} \\
(0.012)\end{array}$ & $\begin{array}{c}0.069 * * * \\
(0.016)\end{array}$ & $\begin{array}{c}0.077 * * * \\
(0.017)\end{array}$ & $\begin{array}{c}0.078 * * \\
(0.032)\end{array}$ & $\begin{array}{l}-0.004 \\
(0.023)\end{array}$ \\
\hline $\begin{array}{l}2^{\text {nd }} \text { hh. income } \\
\text { quartile }\end{array}$ & $\begin{array}{l}-0.020 \\
(0.015)\end{array}$ & $\begin{array}{l}-0.005 \\
(0.026)\end{array}$ & $\begin{array}{c}0.012 \\
(0.025)\end{array}$ & $\begin{array}{c}0.020 \\
(0.021)\end{array}$ & $\begin{array}{c}0.028 \\
(0.025)\end{array}$ & $\begin{array}{c}0.002 \\
(0.016)\end{array}$ \\
\hline $\begin{array}{l}3^{\text {rd }} \text { hh. income } \\
\text { guartile }\end{array}$ & $\begin{array}{c}-0.070 * * * \\
(0.016)\end{array}$ & $\begin{array}{c}0.038 \\
(0.041)\end{array}$ & $\begin{array}{c}0.077 * * \\
(0.034)\end{array}$ & $\begin{array}{l}0.090 * * \\
(0.032)\end{array}$ & $\begin{array}{c}0.123 * * * \\
(0.034)\end{array}$ & $\begin{array}{c}0.021 \\
(0.023)\end{array}$ \\
\hline $\begin{array}{l}4^{\text {th }} \text { hh. income } \\
\text { quartile }\end{array}$ & $\begin{array}{c}-0.238 * * * \\
(0.026)\end{array}$ & $\begin{array}{c}0.181^{* * *} \\
(0.035)\end{array}$ & $\begin{array}{c}0.281 * * * \\
(0.035)\end{array}$ & $\begin{array}{c}0.302 * * * \\
(0.030)\end{array}$ & $\begin{array}{c}0.417 * * * \\
(0.031)\end{array}$ & $\begin{array}{c}0.077 * * * \\
(0.017)\end{array}$ \\
\hline Czech Republic & $\begin{array}{c}-0.328 * * * \\
(0.037)\end{array}$ & $\begin{array}{c}0.455 * * * \\
(0.043)\end{array}$ & $\begin{array}{c}0.520 * * * \\
(0.014)\end{array}$ & & & \\
\hline Slovakia & $\begin{array}{c}0.209 * * * \\
(0.011)\end{array}$ & $\begin{array}{c}-0.191 * * * \\
(0.022)\end{array}$ & $\begin{array}{c}-0.255^{* * *} \\
(0.012)\end{array}$ & & & \\
\hline Hungary & $\begin{array}{c}0.375^{* * *} \\
(0.027)\end{array}$ & $\begin{array}{c}-0.173 * * * \\
(0.034)\end{array}$ & $\begin{array}{c}-0.385^{* * *} * \\
(0.014)\end{array}$ & & & \\
\hline Poland & $\begin{array}{c}-0.122 * * * \\
(0.031)\end{array}$ & $\begin{array}{c}0.014 \\
(0.035)\end{array}$ & $\begin{array}{c}0.119 * * * \\
(0.012)\end{array}$ & & & \\
\hline Estonia & $\begin{array}{c}0.248 * * * \\
(0.030)\end{array}$ & $\begin{array}{c}0.234 * * * \\
(0.040)\end{array}$ & $\begin{array}{l}-0.036 \\
(0.035)\end{array}$ & & & \\
\hline Lithiania & $\begin{array}{c}0.600 * * * \\
(0.031)\end{array}$ & $\begin{array}{c}-0.444 * * * \\
(0.037)\end{array}$ & $\begin{array}{c}-0.679 * * * \\
(0.034)\end{array}$ & & & \\
\hline Latvia & $\begin{array}{c}0.413 * * * \\
(0.031)\end{array}$ & $\begin{array}{c}-0.429 * * * \\
(0.038)\end{array}$ & $\begin{array}{c}-0.532 * * * \\
(0.035)\end{array}$ & & & \\
\hline Bulgaria & $\begin{array}{c}0.173 * * * \\
(0.011)\end{array}$ & $\begin{array}{c}-0.477 * * * \\
(0.013)\end{array}$ & $\begin{array}{c}-0.367 * * * \\
(0.009)\end{array}$ & & & \\
\hline Romania & $\begin{array}{c}-0.066 * * \\
(0.028)\end{array}$ & $\begin{array}{c}-0.245 * * * \\
(0.039)\end{array}$ & $\begin{array}{c}-0.101 * * * \\
(0.031)\end{array}$ & & & \\
\hline Croatia & $\begin{array}{c}-0.357 * * * \\
(0.071)\end{array}$ & $\begin{array}{c}-0.107 \\
(0.074)\end{array}$ & $\begin{array}{c}0.218 * * * \\
(0.036)\end{array}$ & & & \\
\hline Russia & $\begin{array}{c}0.562 * * * \\
(0.032)\end{array}$ & $\begin{array}{c}-0.538 * * * \\
(0.034)\end{array}$ & $\begin{array}{c}-0.689 * * * \\
(0.027)\end{array}$ & & & \\
\hline Ukraine & $\begin{array}{c}0.765^{* * * *} \\
(0.021)\end{array}$ & $\begin{array}{c}-0.844 * * * \\
(0.027)\end{array}$ & $\begin{array}{c}-1.054 * * * \\
(0.018)\end{array}$ & & & \\
\hline Belarus & $\begin{array}{c}0.668 * * * \\
(0.019)\end{array}$ & $\begin{array}{c}-0.406 * * * \\
(0.033)\end{array}$ & $\begin{array}{c}-0.753 * * * \\
(0.022)\end{array}$ & & & \\
\hline 1991 & $\begin{array}{c}-0.406 * * * \\
(0.093)\end{array}$ & $\begin{array}{c}-0.680 * * * \\
(0.165)\end{array}$ & $\begin{array}{l}-0.164 \\
(0.134)\end{array}$ & & & \\
\hline 1992 & $\begin{array}{c}-0.272 * * \\
(0.119)\end{array}$ & $\begin{array}{c}-0.860 * * * \\
(0.198)\end{array}$ & $\begin{array}{c}-0.368 * * * \\
(0.114)\end{array}$ & & & \\
\hline 1993 & $-0.158^{* *}$ & $-0.609 * * *$ & $-0.289 * *$ & & & \\
\hline
\end{tabular}




\begin{tabular}{|c|c|c|c|c|c|c|}
\hline & $(0.071)$ & $(0.147)$ & $(0.124)$ & & & \\
\hline 1995 & $\begin{array}{l}-0.049 \\
(0.093)\end{array}$ & $\begin{array}{c}-0.591 * * * \\
(0.168)\end{array}$ & $\begin{array}{c}-0.344 * * \\
(0.152)\end{array}$ & & & \\
\hline 1996 & $\begin{array}{l}-0.167 \\
(0.123)\end{array}$ & $\begin{array}{c}-0.524 * * * \\
(0.131)\end{array}$ & $\begin{array}{l}-0.216 \\
(0.144)\end{array}$ & & & \\
\hline 1998 & $\begin{array}{c}-0.156 \\
(0.117)\end{array}$ & $\begin{array}{c}-0.577 * * * \\
(0.158)\end{array}$ & $\begin{array}{c}-0.248 \\
(0.147)\end{array}$ & & & \\
\hline 2000 & $\begin{array}{c}0.101 \\
(0.099)\end{array}$ & $\begin{array}{c}-0.446 * * \\
(0.150)\end{array}$ & $\begin{array}{c}-0.312 * * \\
(0.128)\end{array}$ & & & \\
\hline 2001 & $\begin{array}{c}-0.156 * * \\
(0.071)\end{array}$ & $\begin{array}{l}-0.102 \\
(0.146)\end{array}$ & $\begin{array}{c}0.043 \\
(0.104)\end{array}$ & & & \\
\hline Constant & $\begin{array}{c}0.470 * * * \\
(0.089)\end{array}$ & $\begin{array}{l}0.433 * * \\
(0.148)\end{array}$ & $\begin{array}{c}-0.058 \\
(0.143)\end{array}$ & $\begin{array}{c}-0.353 * * * \\
(0.072)\end{array}$ & $\begin{array}{c}-0.574 * * * \\
(0.092)\end{array}$ & $\begin{array}{c}0.902 * * * \\
(0.036)\end{array}$ \\
\hline $\begin{array}{l}\text { Country*year } \\
\text { dummies }\end{array}$ & No & No & No & Yes & Yes & Yes \\
\hline Observations & 72648 & 73636 & 72012 & 72012 & 41050 & 9779 \\
\hline R-squared & 0.16 & 0.15 & 0.19 & 0.22 & 0.29 & 0.05 \\
\hline
\end{tabular}

Notes: Estimation method: OLS. Standard errors clustered by country are reported in parentheses. * significant at 10 percent; ** significant at 5 percent; *** significant at 1 percent. Dependent variables in columns (1) and (2) are standardized individuals' rankings of past or present economic systems, respectively. Dependent variable in columns (3)-(6) is the standardized distance between the rankings of present and past economic systems. Reference individual is male, age 20-29, cohort between 18 and 55 years old in 1990, less than secondary school education, married, living in rural or small town, employed, with household income in the 1st quartile. Reference country and year: Slovenia, 2004. In columns (4)-(6) the additional reference category is Slovenia*2004. For definitions of variables, see text and Data Appendix. 
Table 4. Determinants of support for the political system: Present versus past

\begin{tabular}{|c|c|c|c|c|c|c|}
\hline & $\begin{array}{l}(1) \\
\text { Past }\end{array}$ & $\begin{array}{c}(2) \\
\text { Present }\end{array}$ & $\begin{array}{c}(3) \\
\text { Distance }\end{array}$ & $\begin{array}{c}(4) \\
\text { Distance }\end{array}$ & $\begin{array}{c}(5) \\
\text { Distance if } \\
\text { democrat }=1 \\
\text { or } \\
\text { reactionary=1 }\end{array}$ & $\begin{array}{c}(6) \\
\text { Distance if } \\
\text { democrat }=1\end{array}$ \\
\hline Female & $\begin{array}{c}0.073 * * * \\
(0.024)\end{array}$ & $\begin{array}{c}-0.066^{* *} \\
(0.029)\end{array}$ & $\begin{array}{c}-0.093 * * \\
(0.033)\end{array}$ & $\begin{array}{c}-0.092 * * \\
(0.033)\end{array}$ & $\begin{array}{c}-0.151 * * * \\
(0.050)\end{array}$ & $\begin{array}{c}0.003 \\
(0.009)\end{array}$ \\
\hline Young_cohort & $\begin{array}{c}-0.034 * * \\
(0.015)\end{array}$ & $\begin{array}{c}0.095 * * * \\
(0.023)\end{array}$ & $\begin{array}{c}0.079 * * * \\
(0.017)\end{array}$ & $\begin{array}{c}0.068 * * * \\
(0.018)\end{array}$ & $\begin{array}{c}0.120 * * * \\
(0.031)\end{array}$ & $\begin{array}{l}-0.023 \\
(0.028)\end{array}$ \\
\hline Age 30-39 & $\begin{array}{c}0.035 * * * \\
(0.010)\end{array}$ & $\begin{array}{l}-0.018 \\
(0.018)\end{array}$ & $\begin{array}{c}-0.038^{* *} \\
(0.013)\end{array}$ & $\begin{array}{c}-0.035 * * \\
(0.013)\end{array}$ & $\begin{array}{c}-0.066^{* *} * \\
(0.023)\end{array}$ & $\begin{array}{c}0.012 \\
(0.015)\end{array}$ \\
\hline Age $40-49$ & $\begin{array}{c}0.135 * * * \\
(0.011)\end{array}$ & $\begin{array}{c}-0.036 \\
(0.025)\end{array}$ & $\begin{array}{c}-0.120 * * * \\
(0.017)\end{array}$ & $\begin{array}{c}-0.129 * * * \\
(0.018)\end{array}$ & $\begin{array}{c}-0.196 * * * \\
(0.027)\end{array}$ & $\begin{array}{l}-0.001 \\
(0.023)\end{array}$ \\
\hline Age 50-59 & $\begin{array}{c}0.159 * * * \\
(0.024)\end{array}$ & $\begin{array}{l}-0.049 \\
(0.029)\end{array}$ & $\begin{array}{c}-0.145 * * * \\
(0.029)\end{array}$ & $\begin{array}{c}-0.144 * * * \\
(0.029)\end{array}$ & $\begin{array}{c}-0.206 * * * \\
(0.031)\end{array}$ & $\begin{array}{c}0.029 \\
(0.025)\end{array}$ \\
\hline Age $>60$ & $\begin{array}{c}0.114 * * \\
(0.046)\end{array}$ & $\begin{array}{l}-0.051 \\
(0.044)\end{array}$ & $\begin{array}{c}-0.116 * * \\
(0.054)\end{array}$ & $\begin{array}{c}-0.113^{*} * \\
(0.051)\end{array}$ & $\begin{array}{c}-0.161^{* *} \\
(0.063)\end{array}$ & $\begin{array}{c}0.051 \\
(0.033)\end{array}$ \\
\hline $\begin{array}{l}\text { Secondary / } \\
\text { vocational }\end{array}$ & $\begin{array}{c}-0.138 * * * \\
(0.025)\end{array}$ & $\begin{array}{c}0.075^{* * *} * \\
(0.021)\end{array}$ & $\begin{array}{c}0.137 * * * \\
(0.025)\end{array}$ & $\begin{array}{c}0.122 * * * \\
(0.023)\end{array}$ & $\begin{array}{c}0.179 * * * \\
(0.036)\end{array}$ & $\begin{array}{c}0.049 * * * \\
(0.015)\end{array}$ \\
\hline University & $\begin{array}{c}-0.354 * * * \\
(0.020)\end{array}$ & $\begin{array}{c}0.155^{* * *} * \\
(0.039)\end{array}$ & $\begin{array}{c}0.342 * * * \\
(0.027)\end{array}$ & $\begin{array}{c}0.321 * * * \\
(0.023)\end{array}$ & $\begin{array}{c}0.471 * * * \\
(0.045)\end{array}$ & $\begin{array}{c}0.084 * * * \\
(0.022)\end{array}$ \\
\hline Single & $\begin{array}{c}-0.068 * * * \\
(0.018)\end{array}$ & $\begin{array}{l}-0.002 \\
(0.014)\end{array}$ & $\begin{array}{c}0.047 * * \\
(0.018)\end{array}$ & $\begin{array}{c}0.049 * * * \\
(0.016)\end{array}$ & $\begin{array}{c}0.043 \\
(0.028)\end{array}$ & $\begin{array}{l}-0.003 \\
(0.023)\end{array}$ \\
\hline $\begin{array}{l}\text { Divorced / } \\
\text { widowed }\end{array}$ & $\begin{array}{c}-0.013 \\
(0.013)\end{array}$ & $\begin{array}{c}-0.012 \\
(0.020)\end{array}$ & $\begin{array}{c}0.003 \\
(0.020)\end{array}$ & $\begin{array}{c}0.001 \\
(0.018)\end{array}$ & $\begin{array}{c}-0.017 \\
(0.022)\end{array}$ & $\begin{array}{c}-0.011 \\
(0.013)\end{array}$ \\
\hline City & $\begin{array}{c}-0.126 * * \\
(0.051)\end{array}$ & $\begin{array}{c}0.004 \\
(0.032)\end{array}$ & $\begin{array}{c}0.091^{*} \\
(0.050)\end{array}$ & $\begin{array}{c}0.100 * \\
(0.046)\end{array}$ & $\begin{array}{l}0.141^{*} \\
(0.067)\end{array}$ & $\begin{array}{c}0.087 * * * \\
(0.018)\end{array}$ \\
\hline Big town & $\begin{array}{l}-0.017 \\
(0.034)\end{array}$ & $\begin{array}{c}-0.048 * \\
(0.023)\end{array}$ & $\begin{array}{l}-0.016 \\
(0.032)\end{array}$ & $\begin{array}{c}0.004 \\
(0.031)\end{array}$ & $\begin{array}{c}0.006 \\
(0.047)\end{array}$ & $\begin{array}{c}0.046 * * \\
(0.017)\end{array}$ \\
\hline Unemployed & $\begin{array}{c}0.098 * * * \\
(0.025)\end{array}$ & $\begin{array}{c}-0.091 * * * \\
(0.023)\end{array}$ & $\begin{array}{c}-0.126 * * * \\
(0.029)\end{array}$ & $\begin{array}{c}-0.115 * * * \\
(0.028)\end{array}$ & $\begin{array}{c}-0.180 * * * \\
(0.038)\end{array}$ & $\begin{array}{c}0.033 * * * \\
(0.011)\end{array}$ \\
\hline Pensioner & $\begin{array}{c}0.078^{* * *} \\
(0.017)\end{array}$ & $\begin{array}{c}0.042 \\
(0.031)\end{array}$ & $\begin{array}{l}-0.026 \\
(0.026)\end{array}$ & $\begin{array}{l}-0.029 \\
(0.023)\end{array}$ & $\begin{array}{l}-0.025 \\
(0.040)\end{array}$ & $\begin{array}{l}0.048 * * \\
(0.017)\end{array}$ \\
\hline $\begin{array}{l}\text { Student / } \\
\text { housewife }\end{array}$ & $\begin{array}{c}-0.050 * * \\
(0.023)\end{array}$ & $\begin{array}{c}0.050 * * \\
(0.017)\end{array}$ & $\begin{array}{c}0.063 * * * \\
(0.020)\end{array}$ & $\begin{array}{c}0.070 * * * \\
(0.020)\end{array}$ & $\begin{array}{c}0.087 * * \\
(0.030)\end{array}$ & $\begin{array}{c}0.021 \\
(0.018)\end{array}$ \\
\hline $\begin{array}{l}2^{\text {nd }} \text { hh. income } \\
\text { quartile }\end{array}$ & $\begin{array}{c}-0.037 * * \\
(0.017)\end{array}$ & $\begin{array}{c}0.019 \\
(0.021)\end{array}$ & $\begin{array}{l}0.040 * \\
(0.022)\end{array}$ & $\begin{array}{c}0.051^{* * *} \\
(0.016)\end{array}$ & $\begin{array}{c}0.077^{*} * * \\
(0.024)\end{array}$ & $\begin{array}{c}0.010 \\
(0.017)\end{array}$ \\
\hline $\begin{array}{l}3^{\text {rd }} \text { hh. income } \\
\text { quartile }\end{array}$ & $\begin{array}{c}-0.107 * * * \\
(0.019)\end{array}$ & $\begin{array}{l}0.073 * * \\
(0.027)\end{array}$ & $\begin{array}{c}0.120 * * * \\
(0.025)\end{array}$ & $\begin{array}{c}0.130 * * * \\
(0.023)\end{array}$ & $\begin{array}{c}0.181 * * * \\
(0.035)\end{array}$ & $\begin{array}{c}0.024 \\
(0.015)\end{array}$ \\
\hline $\begin{array}{l}4^{\text {th }} \text { hh. income } \\
\text { quartile }\end{array}$ & $\begin{array}{c}-0.234 * * * \\
(0.030)\end{array}$ & $\begin{array}{c}0.153 * * * \\
(0.026)\end{array}$ & $\begin{array}{c}0.260 * * * \\
(0.031)\end{array}$ & $\begin{array}{c}0.275^{* * *} \\
(0.025)\end{array}$ & $\begin{array}{c}0.409 * * * \\
(0.045)\end{array}$ & $\begin{array}{c}0.063 * * * \\
(0.016)\end{array}$ \\
\hline Czech Republic & $\begin{array}{c}-0.533 * * * \\
(0.025)\end{array}$ & $\begin{array}{c}0.429 * * * \\
(0.047)\end{array}$ & $\begin{array}{c}0.568 * * * \\
(0.025)\end{array}$ & & & \\
\hline Slovakia & $\begin{array}{c}0.001 \\
(0.010)\end{array}$ & $\begin{array}{c}-0.101 * * * \\
(0.022)\end{array}$ & $\begin{array}{c}-0.081 * * * \\
(0.015)\end{array}$ & & & \\
\hline Hungary & $\begin{array}{c}0.284 * * * \\
(0.024)\end{array}$ & $\begin{array}{c}-0.141 * * * \\
(0.030)\end{array}$ & $\begin{array}{c}-0.309 * * * \\
(0.016)\end{array}$ & & & \\
\hline Poland & $\begin{array}{c}-0.224 * * * \\
(0.027)\end{array}$ & $\begin{array}{c}0.034 \\
(0.032)\end{array}$ & $\begin{array}{c}0.159 * * * \\
(0.017)\end{array}$ & & & \\
\hline Estonia & $\begin{array}{l}0.064 * * \\
(0.024)\end{array}$ & $\begin{array}{c}0.027 \\
(0.035)\end{array}$ & $\begin{array}{c}-0.063 * \\
(0.032)\end{array}$ & & & \\
\hline Lithuania & $\begin{array}{c}0.106 * * * \\
(0.025)\end{array}$ & $\begin{array}{c}-0.337 * * * \\
(0.036)\end{array}$ & $\begin{array}{c}-0.301 * * * \\
(0.032)\end{array}$ & & & \\
\hline Latvia & $\begin{array}{c}0.093 * * * \\
(0.024)\end{array}$ & $\begin{array}{c}-0.398 * * * \\
(0.035)\end{array}$ & $\begin{array}{c}-0.323 * * * \\
(0.033)\end{array}$ & & & \\
\hline Bulgaria & $\begin{array}{c}0.035^{* *} \\
(0.013)\end{array}$ & $\begin{array}{l}-0.013 \\
(0.018)\end{array}$ & $\begin{array}{c}-0.067 * * * \\
(0.014)\end{array}$ & & & \\
\hline Romania & $\begin{array}{c}-0.328 * * * \\
(0.027)\end{array}$ & $\begin{array}{c}0.160 * * * \\
(0.031)\end{array}$ & $\begin{array}{c}0.340 * * * \\
(0.026)\end{array}$ & & & \\
\hline Croatia & $\begin{array}{c}-0.564 * * * \\
(0.055)\end{array}$ & $\begin{array}{c}-0.208 * * \\
(0.090)\end{array}$ & $\begin{array}{c}0.265^{* * *} * \\
(0.036)\end{array}$ & & & \\
\hline Russia & $\begin{array}{c}0.435 * * * \\
(0.020)\end{array}$ & $\begin{array}{c}-0.577 * * * \\
(0.031)\end{array}$ & $\begin{array}{c}-0.676 * * * \\
(0.021)\end{array}$ & & & \\
\hline Ukraine & $\begin{array}{c}0.431 * * * \\
(0.017)\end{array}$ & $\begin{array}{c}-0.488 * * * \\
(0.028)\end{array}$ & $\begin{array}{c}-0.625^{* * *} \\
(0.024)\end{array}$ & & & \\
\hline Belarus & $\begin{array}{c}0.420 * * * \\
(0.016)\end{array}$ & $\begin{array}{c}-0.348 * * * \\
(0.028)\end{array}$ & $\begin{array}{c}-0.533 * * * \\
(0.026)\end{array}$ & & & \\
\hline 1991 & $\begin{array}{c}-0.447 * * * \\
(0.088)\end{array}$ & $\begin{array}{l}-0.165 \\
(0.164)\end{array}$ & $\begin{array}{c}0.218 \\
(0.142)\end{array}$ & & & \\
\hline 1992 & $\begin{array}{c}-0.295 * * * \\
(0.091)\end{array}$ & $\begin{array}{l}-0.421^{*} \\
(0.224)\end{array}$ & $\begin{array}{c}-0.045 \\
(0.108)\end{array}$ & & & \\
\hline 1993 & $-0.231 * * *$ & -0.190 & 0.045 & & & \\
\hline
\end{tabular}




\begin{tabular}{|c|c|c|c|c|c|c|}
\hline & $(0.065)$ & $(0.141)$ & $(0.108)$ & & & \\
\hline 1995 & $-0.192 * *$ & -0.184 & $\begin{array}{c}0.026 \\
(0.134)\end{array}$ & & & \\
\hline 1996 & $-0.287 * * *$ & $-0.290 * *$ & 0.037 & & & \\
\hline 1998 & $\begin{array}{c}(0.059) \\
-0.132 \\
(0.099)\end{array}$ & $\begin{array}{l}(0.116) \\
-0.306 *\end{array}$ & $\begin{array}{l}(0.095) \\
-0.086\end{array}$ & & & \\
\hline 2000 & $\begin{array}{c}0.012 \\
(0.059)\end{array}$ & $\begin{array}{l}-0.147 \\
(0.122)\end{array}$ & $\begin{array}{c}-0.084 \\
(0.086)\end{array}$ & & & \\
\hline 2001 & $\begin{array}{c}0.022 \\
(0.074)\end{array}$ & $\begin{array}{c}0.012 \\
(0.120)\end{array}$ & $\begin{array}{c}-0.000 \\
(0.090)\end{array}$ & & & \\
\hline Constant & $\begin{array}{c}0.322 * * * \\
(0.076)\end{array}$ & $\begin{array}{c}0.364 * * \\
(0.137)\end{array}$ & $\begin{array}{c}0.016 \\
(0.123)\end{array}$ & $\begin{array}{c}-0.171 * * * \\
(0.053)\end{array}$ & $\begin{array}{c}-0.186 * * \\
(0.084)\end{array}$ & $\begin{array}{c}1.034 * * * \\
(0.036)\end{array}$ \\
\hline $\begin{array}{l}\text { Country* year } \\
\text { dummies }\end{array}$ & No & No & No & Yes & Yes & Yes \\
\hline Observations & 71337 & 72262 & 70532 & 70532 & 38358 & 18684 \\
\hline R-squared & 0.15 & 0.10 & 0.17 & 0.19 & 0.29 & 0.07 \\
\hline
\end{tabular}

Notes: Estimation method: OLS. Standard errors clustered by country are reported in parentheses. * significant at 10 percent; ** significant at 5 percent; *** significant at 1 percent. Dependent variables in columns (1) and (2) are standardized individuals' rankings of past or present political systems, respectively. Dependent variable in columns (3)-(6) is the standardized distance between the rankings of present and past economic systems. Reference individual is male, age 20-29, cohort between 18 and 55 years old in 1990, less than secondary school education, married, living in rural or small town, employed, with household income in the 1st quartile. Reference country and year: Slovenia, 2004. In columns (4)-(6) the additional reference category is Slovenia*2004. For definitions of variables, see text and Data Appendix. 
Table 5. Determinants of support - present versus past, SUR model

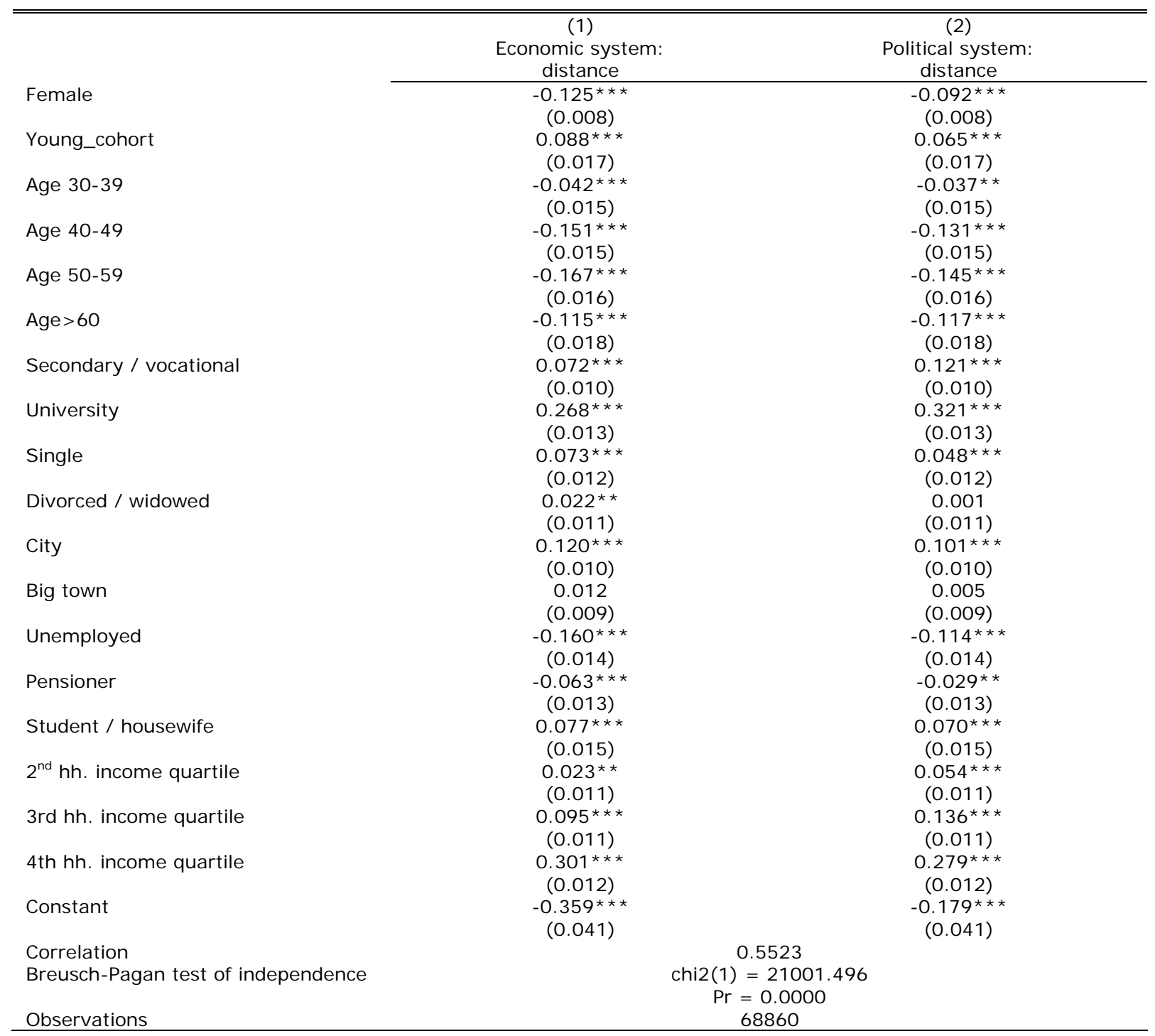

Notes: Estimation method: SUR. Standard errors in parentheses. * significant at 10 percent; ** significant at 5 percent; *** significant at 1 percent. Dependent variables are the standardized distances between rankings of present and past economic and political systems. Reference categories as in Tables 3 and 4 column (4). Additional regressors include interactions between country and year dummies. For definitions of variables, see text and Data Appendix. 
Table 6. Determinants of adhesion to a group

\begin{tabular}{|c|c|c|c|c|c|c|}
\hline & (1) & (2) & (3) & (4) & (5) & (6) \\
\hline & \multicolumn{3}{|c|}{ Economic system } & \multicolumn{3}{|c|}{ Political system } \\
\hline & Positive & Pro-market & Nostalgic & Compliant & Democrat & Reactionary \\
\hline Female & $\begin{array}{l}-0.016 \\
(0.012)\end{array}$ & $\begin{array}{c}-0.022 * * * \\
(0.008)\end{array}$ & $\begin{array}{c}0.055^{* * *} \\
(0.021)\end{array}$ & $\begin{array}{c}0.006 \\
(0.005)\end{array}$ & $\begin{array}{c}-0.035 * * * \\
(0.009)\end{array}$ & $\begin{array}{c}0.031 * * \\
(0.013)\end{array}$ \\
\hline Young_cohort & $\begin{array}{c}0.016 \\
(0.011)\end{array}$ & $\begin{array}{c}0.016 * * \\
(0.007)\end{array}$ & $\begin{array}{c}-0.042 * * * \\
(0.012)\end{array}$ & $\begin{array}{c}0.010 \\
(0.011)\end{array}$ & $\begin{array}{l}0.019 * * \\
(0.008)\end{array}$ & $\begin{array}{c}-0.038 * * * \\
(0.009)\end{array}$ \\
\hline Age 30-39 & $\begin{array}{l}-0.004 \\
(0.006)\end{array}$ & $\begin{array}{c}-0.012 * * \\
(0.006)\end{array}$ & $\begin{array}{l}0.015^{*} \\
(0.008)\end{array}$ & $\begin{array}{l}0.005 \\
(0.008)\end{array}$ & $\begin{array}{c}-0.014 * \\
(0.007)\end{array}$ & $\begin{array}{l}0.013 * * \\
(0.006)\end{array}$ \\
\hline Age $40-49$ & $\begin{array}{c}-0.013 \\
(0.009)\end{array}$ & $\begin{array}{c}-0.030 * * * \\
(0.006)\end{array}$ & $\begin{array}{c}0.064 * * * \\
(0.008)\end{array}$ & $\begin{array}{c}0.013 \\
(0.012)\end{array}$ & $\begin{array}{c}-0.039 * * * \\
(0.009)\end{array}$ & $\begin{array}{c}0.057 * * * \\
(0.009)\end{array}$ \\
\hline Age $50-59$ & $\begin{array}{l}-0.003 \\
(0.008)\end{array}$ & $\begin{array}{c}-0.034 * * * \\
(0.006)\end{array}$ & $\begin{array}{c}0.061 * * * \\
(0.012)\end{array}$ & $\begin{array}{l}0.019 * \\
(0.011)\end{array}$ & $\begin{array}{c}-0.045^{* * *} \\
(0.010)\end{array}$ & $\begin{array}{c}0.065^{* * *} * \\
(0.014)\end{array}$ \\
\hline Age $>60$ & $\begin{array}{c}0.000 \\
(0.014)\end{array}$ & $\begin{array}{c}-0.020 * \\
(0.011)\end{array}$ & $\begin{array}{c}0.038 * \\
(0.023)\end{array}$ & $\begin{array}{c}0.008 \\
(0.013)\end{array}$ & $\begin{array}{c}-0.032 * \\
(0.017)\end{array}$ & $\begin{array}{c}0.057 * * * \\
(0.021)\end{array}$ \\
\hline $\begin{array}{l}\text { Secondary / } \\
\text { vocational }\end{array}$ & $\begin{array}{c}0.005 \\
(0.006)\end{array}$ & $\begin{array}{c}0.020 * * * \\
(0.006)\end{array}$ & $\begin{array}{c}-0.034 * * * \\
(0.011)\end{array}$ & $\begin{array}{l}-0.002 \\
(0.006)\end{array}$ & $\begin{array}{c}0.043^{* * *} * \\
(0.010)\end{array}$ & $\begin{array}{c}-0.044 * * * \\
(0.008)\end{array}$ \\
\hline University & $\begin{array}{c}0.002 \\
(0.011)\end{array}$ & $\begin{array}{c}0.068 * * * \\
(0.008)\end{array}$ & $\begin{array}{c}-0.116 * * * \\
(0.014)\end{array}$ & $\begin{array}{c}-0.025 * * * \\
(0.007)\end{array}$ & $\begin{array}{c}0.117 * * * \\
(0.011)\end{array}$ & $\begin{array}{c}-0.107 * * * \\
(0.009)\end{array}$ \\
\hline Single & $\begin{array}{l}-0.004 \\
(0.007)\end{array}$ & $\begin{array}{c}0.010 * \\
(0.006)\end{array}$ & $\begin{array}{c}-0.025 * * * \\
(0.006)\end{array}$ & $\begin{array}{c}-0.013^{*} \\
(0.007)\end{array}$ & $\begin{array}{l}0.015^{*} \\
(0.009)\end{array}$ & $\begin{array}{c}-0.015^{*} * \\
(0.006)\end{array}$ \\
\hline $\begin{array}{l}\text { Divorced / } \\
\text { widowed }\end{array}$ & $\begin{array}{c}-0.008 * * * \\
(0.003)\end{array}$ & $\begin{array}{l}-0.000 \\
(0.004)\end{array}$ & $\begin{array}{c}0.001 \\
(0.006)\end{array}$ & $\begin{array}{c}-0.013^{* *} * \\
(0.006)\end{array}$ & $\begin{array}{l}-0.003 \\
(0.006)\end{array}$ & $\begin{array}{c}0.007 \\
(0.008)\end{array}$ \\
\hline City & $\begin{array}{l}-0.009 \\
(0.011)\end{array}$ & $\begin{array}{c}0.026 * * \\
(0.010)\end{array}$ & $\begin{array}{c}-0.054 * * * \\
(0.016)\end{array}$ & $\begin{array}{c}-0.023^{*} \\
(0.014)\end{array}$ & $\begin{array}{c}0.028 \\
(0.020)\end{array}$ & $\begin{array}{c}-0.033 * * \\
(0.016)\end{array}$ \\
\hline Big town & $\begin{array}{c}0.003 \\
(0.007)\end{array}$ & $\begin{array}{c}0.004 \\
(0.005)\end{array}$ & $\begin{array}{l}-0.012 \\
(0.010)\end{array}$ & $\begin{array}{l}-0.004 \\
(0.008)\end{array}$ & $\begin{array}{l}-0.000 \\
(0.012)\end{array}$ & $\begin{array}{l}-0.002 \\
(0.012)\end{array}$ \\
\hline Unemployed & $\begin{array}{l}-0.012 \\
(0.008)\end{array}$ & $\begin{array}{c}-0.030 * * * \\
(0.005)\end{array}$ & $\begin{array}{c}0.058 * * * \\
(0.013)\end{array}$ & $\begin{array}{c}0.000 \\
(0.008)\end{array}$ & $\begin{array}{c}-0.043^{* * *} \\
(0.008)\end{array}$ & $\begin{array}{c}0.052 * * * \\
(0.013)\end{array}$ \\
\hline Pensioner & $\begin{array}{c}0.006 \\
(0.010)\end{array}$ & $\begin{array}{c}-0.020 * * * \\
(0.007)\end{array}$ & $\begin{array}{c}0.028 * * \\
(0.012)\end{array}$ & $\begin{array}{c}0.014 \\
(0.009)\end{array}$ & $\begin{array}{l}-0.014 \\
(0.010)\end{array}$ & $\begin{array}{c}0.009 \\
(0.010)\end{array}$ \\
\hline $\begin{array}{l}\text { Student / } \\
\text { housewife }\end{array}$ & $\begin{array}{c}0.009 \\
(0.007)\end{array}$ & $\begin{array}{c}0.013^{*} * \\
(0.006)\end{array}$ & $\begin{array}{c}-0.035 * * * \\
(0.008)\end{array}$ & $\begin{array}{c}-0.017 * * \\
(0.007)\end{array}$ & $\begin{array}{c}0.034 * * * \\
(0.009)\end{array}$ & $\begin{array}{l}-0.016 \\
(0.011)\end{array}$ \\
\hline $\begin{array}{l}\text { 2nd hh. income } \\
\text { quartile }\end{array}$ & $\begin{array}{c}0.004 \\
(0.007)\end{array}$ & $\begin{array}{c}0.006 \\
(0.005)\end{array}$ & $\begin{array}{l}-0.016 \\
(0.011)\end{array}$ & $\begin{array}{l}-0.000 \\
(0.005)\end{array}$ & $\begin{array}{c}0.018 * * * \\
(0.006)\end{array}$ & $\begin{array}{c}-0.016 * * * \\
(0.005)\end{array}$ \\
\hline $\begin{array}{l}\text { 3rd hh. income } \\
\text { quartile }\end{array}$ & $\begin{array}{c}0.007 \\
(0.009)\end{array}$ & $\begin{array}{c}0.021 * * * \\
(0.004)\end{array}$ & $\begin{array}{c}-0.037 * * * \\
(0.014)\end{array}$ & $\begin{array}{c}-0.011 * * \\
(0.005)\end{array}$ & $\begin{array}{c}0.047 * * * \\
(0.006)\end{array}$ & $\begin{array}{c}-0.039 * * * \\
(0.009)\end{array}$ \\
\hline $\begin{array}{l}\text { 4th hh. income } \\
\text { quartile }\end{array}$ & $\begin{array}{c}0.032 * * * \\
(0.009)\end{array}$ & $\begin{array}{c}0.071 * * * \\
(0.009)\end{array}$ & $\begin{array}{c}-0.132 * * * \\
(0.013)\end{array}$ & $\begin{array}{c}-0.017 * * \\
(0.008)\end{array}$ & $\begin{array}{c}0.100 * * * \\
(0.009)\end{array}$ & $\begin{array}{c}-0.093 * * * \\
(0.010)\end{array}$ \\
\hline Observations & 17389 & 9779 & 31271 & 17323 & 18684 & 19674 \\
\hline Observations & & 72012 & & & 70532 & \\
\hline $\begin{array}{l}\text { Pseudo R- } \\
\text { squared }\end{array}$ & & 0.12 & & & 0.09 & \\
\hline
\end{tabular}

Notes: Marginal effects from multinomial logit. Standard errors clustered by country are reported in parentheses. * significant at 10 percent; ** significant at 5 percent; *** significant at 1 percent. All variables definitions as in Tables 3 and 4 column (4). Additional regressors include interactions between country and year dummies. Baseline groups are negative and skeptic, for economic and political outcomes, respectively. For definitions of variables, see text and Data Appendix. 
Table 7. Determinants of support: Alternative dependent variables

\begin{tabular}{|c|c|c|c|c|c|c|}
\hline \multirow[b]{2}{*}{ Female } & \multicolumn{2}{|c|}{$\begin{array}{c}\text { Distance: Economic } \\
\text { OLS }\end{array}$} & \multicolumn{2}{|c|}{$\begin{array}{c}\text { Distance: Political } \\
\text { OLS }\end{array}$} & \multicolumn{2}{|c|}{$\begin{array}{l}\text { Return to communism } \\
\text { Probit, ME }\end{array}$} \\
\hline & $\begin{array}{c}-9.510 * * \\
(3.469)\end{array}$ & $\begin{array}{c}-9.195 * * \\
(3.482)\end{array}$ & $\begin{array}{c}-7.413^{* *} \\
(2.638)\end{array}$ & $\begin{array}{c}-7.576 * * \\
(2.684)\end{array}$ & $\begin{array}{l}0.019 * * \\
(0.007)\end{array}$ & $\begin{array}{c}0.020 * * * \\
(0.007)\end{array}$ \\
\hline Young_cohort & $\begin{array}{c}6.545 * * * \\
(1.526)\end{array}$ & $\begin{array}{c}7.432 * * * \\
(1.323)\end{array}$ & $\begin{array}{c}5.331 * * * \\
(1.400)\end{array}$ & $\begin{array}{c}6.235^{* * *} \\
(1.317)\end{array}$ & $\begin{array}{l}-0.007 \\
(0.008)\end{array}$ & $\begin{array}{l}-0.009 \\
(0.008)\end{array}$ \\
\hline Age 30-39 & $\begin{array}{c}-3.074 * * \\
(1.249)\end{array}$ & $\begin{array}{c}-3.488 * * \\
(1.212)\end{array}$ & $\begin{array}{c}-2.880 * * \\
(1.107)\end{array}$ & $\begin{array}{c}-3.155 * * * \\
(1.047)\end{array}$ & $\begin{array}{c}0.017 \\
(0.012)\end{array}$ & $\begin{array}{c}0.018 \\
(0.011)\end{array}$ \\
\hline Age 40-49 & $\begin{array}{c}-10.918 * * * \\
(1.757)\end{array}$ & $\begin{array}{c}-10.591 * * * \\
(1.783)\end{array}$ & $\begin{array}{c}-10.301 * * * \\
(1.425)\end{array}$ & $\begin{array}{c}-9.641 * * * \\
(1.324)\end{array}$ & $\begin{array}{c}0.070 * * * \\
(0.012)\end{array}$ & $\begin{array}{c}0.070 * * * \\
(0.011)\end{array}$ \\
\hline Age 50-59 & $\begin{array}{c}-12.415^{* * *} * \\
(1.826)\end{array}$ & $\begin{array}{c}-12.486 * * * \\
(1.819)\end{array}$ & $\begin{array}{c}-11.804 * * * \\
(2.187)\end{array}$ & $\begin{array}{c}-11.819 * * * \\
(2.151)\end{array}$ & $\begin{array}{c}0.082 * * * \\
(0.019)\end{array}$ & $\begin{array}{c}0.082 * * * \\
(0.018)\end{array}$ \\
\hline Age $>60$ & $\begin{array}{c}-8.516 * * \\
(3.394)\end{array}$ & $\begin{array}{c}-8.104 * * \\
(3.414)\end{array}$ & $\begin{array}{c}-9.520 * * \\
(3.918)\end{array}$ & $\begin{array}{c}-9.633^{* *} * \\
(4.089)\end{array}$ & $\begin{array}{c}0.082 * * * \\
(0.026)\end{array}$ & $\begin{array}{c}0.079 * * * \\
(0.024)\end{array}$ \\
\hline $\begin{array}{l}\text { Secondary / } \\
\text { vocational }\end{array}$ & $\begin{array}{l}5.572 * * \\
(2.309)\end{array}$ & $\begin{array}{l}7.150 * * \\
(2.378)\end{array}$ & $\begin{array}{c}10.091 * * * \\
(2.294)\end{array}$ & $\begin{array}{c}11.246 * * * \\
(2.392)\end{array}$ & $\begin{array}{c}-0.073 * * * \\
(0.010)\end{array}$ & $\begin{array}{c}-0.079 * * * \\
(0.010)\end{array}$ \\
\hline University & $\begin{array}{c}19.857 * * * \\
(2.264)\end{array}$ & $\begin{array}{c}21.844 * * * \\
(2.031)\end{array}$ & $\begin{array}{l}25.919 * * * \\
(2.133)\end{array}$ & $\begin{array}{c}27.458 * * * \\
(2.473)\end{array}$ & $\begin{array}{c}-0.124 * * * \\
(0.006)\end{array}$ & $\begin{array}{c}-0.129 * * * \\
(0.006)\end{array}$ \\
\hline Single & $\begin{array}{c}5.257 * * * \\
(1.320)\end{array}$ & $\begin{array}{c}4.488 * * \\
(1.642)\end{array}$ & $\begin{array}{c}3.556 * * \\
(1.343)\end{array}$ & $\begin{array}{c}3.345^{* *} \\
(1.471)\end{array}$ & $\begin{array}{l}-0.015 \\
(0.010)\end{array}$ & $\begin{array}{l}-0.011 \\
(0.010)\end{array}$ \\
\hline $\begin{array}{l}\text { Divorced / } \\
\text { widowed }\end{array}$ & $\begin{array}{c}1.721 \\
(1.200)\end{array}$ & $\begin{array}{c}1.036 \\
(1.179)\end{array}$ & $\begin{array}{c}0.553 \\
(1.458)\end{array}$ & $\begin{array}{c}0.735 \\
(1.619)\end{array}$ & $\begin{array}{c}0.010 \\
(0.009)\end{array}$ & $\begin{array}{c}0.012 \\
(0.008)\end{array}$ \\
\hline City & $\begin{array}{l}8.842 * * \\
(3.363)\end{array}$ & $\begin{array}{l}8.379 * * \\
(3.431)\end{array}$ & $\begin{array}{l}8.541 * * \\
(3.876)\end{array}$ & $\begin{array}{l}\text { 7.876* } \\
\text { (4.081) }\end{array}$ & $\begin{array}{c}-0.040 * * * \\
(0.014)\end{array}$ & $\begin{array}{c}-0.040 * * * \\
(0.014)\end{array}$ \\
\hline Big town & $\begin{array}{c}0.980 \\
(1.652)\end{array}$ & $\begin{array}{c}0.239 \\
(1.830)\end{array}$ & $\begin{array}{c}0.385 \\
(2.476)\end{array}$ & $\begin{array}{l}-1.192 \\
(2.600)\end{array}$ & $\begin{array}{l}-0.002 \\
(0.009)\end{array}$ & $\begin{array}{l}-0.000 \\
(0.010)\end{array}$ \\
\hline Unemployed & $\begin{array}{c}-12.135 * * * \\
(2.325)\end{array}$ & $\begin{array}{c}-12.733 * * * \\
(2.643)\end{array}$ & $\begin{array}{c}-9.568 * * * \\
(2.235)\end{array}$ & $\begin{array}{c}-10.342 * * * \\
(2.321)\end{array}$ & $\begin{array}{c}0.047 * * * \\
(0.012)\end{array}$ & $\begin{array}{c}0.047 * * * \\
(0.011)\end{array}$ \\
\hline Pensioner & $\begin{array}{l}-4.546^{*} \\
(2.170)\end{array}$ & $\begin{array}{c}-5.025^{* *} \\
(2.271)\end{array}$ & $\begin{array}{l}-2.397 \\
(2.014)\end{array}$ & $\begin{array}{l}-2.228 \\
(2.082)\end{array}$ & $\begin{array}{c}0.028^{* * * *} \\
(0.009)\end{array}$ & $\begin{array}{c}0.030 * * * \\
(0.009)\end{array}$ \\
\hline $\begin{array}{l}\text { Student / } \\
\text { housewife }\end{array}$ & $\begin{array}{c}5.284 * * * \\
(1.242)\end{array}$ & $\begin{array}{c}4.704 * * * \\
(1.219)\end{array}$ & $\begin{array}{c}5.561 * * * \\
(1.569)\end{array}$ & $\begin{array}{c}5.148 * * * \\
(1.502)\end{array}$ & $\begin{array}{l}-0.002 \\
(0.008)\end{array}$ & $\begin{array}{l}-0.002 \\
(0.009)\end{array}$ \\
\hline $\begin{array}{l}2^{\text {nd }} \text { hh. income } \\
\text { quartile }\end{array}$ & $\begin{array}{l}1.808 \\
(1.565)\end{array}$ & $\begin{array}{l}1.458 \\
(1.801)\end{array}$ & $\begin{array}{c}4.245^{* * *} \\
(1.258)\end{array}$ & $\begin{array}{c}3.410 * \\
(1.718)\end{array}$ & $\begin{array}{c}-0.027 * * * \\
(0.010)\end{array}$ & $\begin{array}{c}-0.024 * * \\
(0.011)\end{array}$ \\
\hline $\begin{array}{l}3^{\text {rd }} \text { hh. income } \\
\text { quartile }\end{array}$ & $\begin{array}{l}7.016 * * \\
(2.388)\end{array}$ & $\begin{array}{l}6.335 * * \\
(2.524)\end{array}$ & $\begin{array}{c}10.717 * * * \\
(1.891)\end{array}$ & $\begin{array}{c}9.871^{* * *} \\
(2.040)\end{array}$ & $\begin{array}{c}-0.060 * * * \\
(0.011)\end{array}$ & $\begin{array}{c}-0.054 * * * \\
(0.013)\end{array}$ \\
\hline $\begin{array}{l}4^{\text {th }} \text { hh. income } \\
\text { quartile }\end{array}$ & $\begin{array}{c}22.624 * * * \\
(2.279)\end{array}$ & $\begin{array}{c}21.231 * * * \\
(2.622)\end{array}$ & $\begin{array}{c}22.509 * * * \\
(2.143)\end{array}$ & $\begin{array}{c}21.314 * * * \\
(2.568)\end{array}$ & $\begin{array}{c}-0.100 * * * \\
(0.013)\end{array}$ & $\begin{array}{c}-0.095^{* * *} \\
(0.015)\end{array}$ \\
\hline Bulgaria & & $\begin{array}{c}-36.083^{* * *} \\
(0.666)\end{array}$ & & $\begin{array}{l}-1.593 \\
(1.183)\end{array}$ & & $\begin{array}{c}0.119 * * * \\
(0.006)\end{array}$ \\
\hline Czech Republic & & $\begin{array}{c}36.765^{* * *} \\
(1.164)\end{array}$ & & $\begin{array}{c}47.909 * * * \\
(1.842)\end{array}$ & & $\begin{array}{c}-0.053 * * * \\
(0.005)\end{array}$ \\
\hline Slovakia & & $\begin{array}{c}-20.976 * * * \\
(0.851)\end{array}$ & & $\begin{array}{c}-4.475 * * * \\
(1.135)\end{array}$ & & $\begin{array}{c}0.095 * * * \\
(0.005)\end{array}$ \\
\hline Hungary & & $\begin{array}{c}-24.845^{* * * *} \\
(1.119)\end{array}$ & & $\begin{array}{c}-21.646 * * * \\
(1.288)\end{array}$ & & $\begin{array}{c}0.031 * * * \\
(0.006)\end{array}$ \\
\hline Poland & & $\begin{array}{c}5.004 * * * \\
(1.070)\end{array}$ & & $\begin{array}{c}12.838 * * * \\
(1.359)\end{array}$ & & $\begin{array}{c}0.036 * * * \\
(0.006)\end{array}$ \\
\hline Romania & & $\begin{array}{c}-10.197 * * * \\
(2.264)\end{array}$ & & $\begin{array}{c}28.203 * * * \\
(2.063)\end{array}$ & & $\begin{array}{c}0.000 \\
(0.012)\end{array}$ \\
\hline Croatia & & $\begin{array}{c}12.546 * * * \\
(2.467)\end{array}$ & & $\begin{array}{c}18.568 * * * \\
(2.901)\end{array}$ & & $\begin{array}{c}-0.057 * * * \\
(0.009)\end{array}$ \\
\hline Belarus & & $\begin{array}{c}-47.864 * * * \\
(1.632)\end{array}$ & & $\begin{array}{c}-40.329 * * * \\
(1.860)\end{array}$ & & $\begin{array}{c}0.245^{* * * *} \\
(0.009)\end{array}$ \\
\hline Ukraine & & $\begin{array}{c}-67.958 * * * \\
(1.315)\end{array}$ & & $\begin{array}{c}-49.247 * * * \\
(1.825)\end{array}$ & & $\begin{array}{c}0.236 * * * \\
(0.005)\end{array}$ \\
\hline Russia & & $\begin{array}{c}-49.882 * * * \\
(2.144)\end{array}$ & & $\begin{array}{c}-49.930 * * * \\
(1.530)\end{array}$ & & $\begin{array}{c}0.256 * * * \\
(0.012)\end{array}$ \\
\hline Estonia & & $\begin{array}{l}-2.587 \\
(2.596)\end{array}$ & & $\begin{array}{l}-2.273 \\
(2.280)\end{array}$ & & $\begin{array}{c}-0.075 * * * \\
(0.007)\end{array}$ \\
\hline Lithuania & & $\begin{array}{c}-48.529 * * * \\
(2.516)\end{array}$ & & $\begin{array}{c}-22.087 * * * \\
(2.403)\end{array}$ & & $\begin{array}{c}-0.056 * * * \\
(0.009)\end{array}$ \\
\hline Latvia & & $\begin{array}{c}-37.048 * * * \\
(2.585)\end{array}$ & & $\begin{array}{c}-22.365^{* * *} * \\
(2.395)\end{array}$ & & $\begin{array}{c}-0.095 * * * \\
(0.006)\end{array}$ \\
\hline 1991 & & $\begin{array}{c}-7.688 \\
(9.378)\end{array}$ & & $\begin{array}{c}16.674 \\
(12.188)\end{array}$ & & \\
\hline 1992 & & $\begin{array}{c}-22.630 * * * \\
(6.795)\end{array}$ & & $\begin{array}{l}-2.792 \\
(9.049)\end{array}$ & & \\
\hline
\end{tabular}




\begin{tabular}{|c|c|c|c|c|c|c|}
\hline 1993 & & $\begin{array}{l}-19.190 * * \\
(7.793)\end{array}$ & & $\begin{array}{c}2.827 \\
(8.702)\end{array}$ & & $\begin{array}{r}-0.038^{*} \\
(0.020)\end{array}$ \\
\hline 1995 & & $-24.078 * *$ & & $\begin{array}{c}0.065 \\
(10851)\end{array}$ & & $\begin{array}{l}-0.009 \\
(0.034)\end{array}$ \\
\hline 1996 & & $\begin{array}{c}-18.191^{*} \\
(9.171)\end{array}$ & & $\begin{array}{c}0.851 \\
(7.711)\end{array}$ & & $\begin{array}{l}-0.013 \\
(0.019)\end{array}$ \\
\hline 1998 & & $\begin{array}{c}-18.084 * \\
(9.994)\end{array}$ & & $\begin{array}{c}-6.412 \\
(12.955)\end{array}$ & & $\begin{array}{c}0.025 \\
(0.034)\end{array}$ \\
\hline 2000 & & $\begin{array}{c}-25.831 * * \\
(9.923)\end{array}$ & & $\begin{array}{l}-8.574 \\
(7.283)\end{array}$ & & $\begin{array}{c}0.011 \\
(0.031)\end{array}$ \\
\hline 2001 & & $\begin{array}{c}0.944 \\
(8.064)\end{array}$ & & $\begin{array}{l}-0.695 \\
(7.586)\end{array}$ & & $\begin{array}{c}0.020 \\
(0.026)\end{array}$ \\
\hline Constant & $\begin{array}{c}-25.777 * * * \\
(5.426)\end{array}$ & $\begin{array}{l}-4.845 \\
(9.962)\end{array}$ & $\begin{array}{c}-13.568 * * * \\
(4.294)\end{array}$ & $\begin{array}{c}-0.877 \\
(10.383)\end{array}$ & & \\
\hline $\begin{array}{l}\text { Observations } \\
\text { R-squared }\end{array}$ & $\begin{array}{c}72012 \\
0.21\end{array}$ & $\begin{array}{c}72012 \\
0.18\end{array}$ & $\begin{array}{c}70532 \\
0.19\end{array}$ & $\begin{array}{c}70532 \\
0.16\end{array}$ & 54553 & 54553 \\
\hline
\end{tabular}

Notes: Standard errors clustered by country are reported in parentheses. * significant at 10 percent; ** significant at 5 percent; *** significant at 1 percent. Dependent variables in columns (1)-(4) are the not standardized distance between the rankings of present and past economic systems, respectively. Dependent variable in columns (5), (6) is equal to one if individual agrees with the statement "we should return to Communist rule". See Tables 3 and 4 for reference categories. Additional regressors in columns (1), (3) and (5) include country and year dummies' interactions 
Table 8. The impact of additional variables: Economic system. Dependent variable: distance

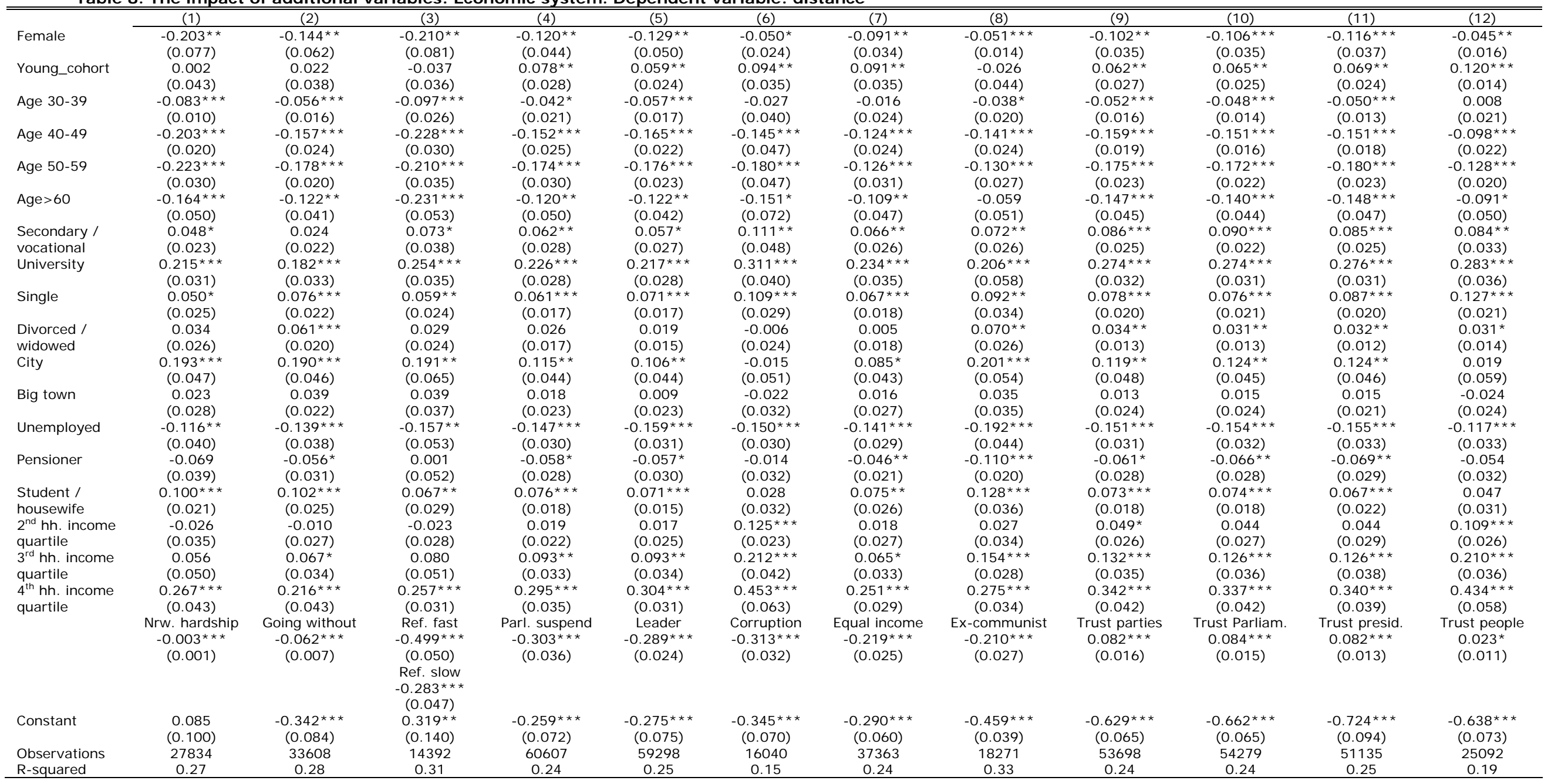

Notes: Estimation method: OLS. Standard errors clustered by country are in parentheses. * significant at 10 percent; ** significant at 5 percent; *** significant at 1 percent. For variables definitions, see text and Data Appendix. Additional controls include country and year dummies interactions. 
Table 9. The impact of additional variables: Political system. Dependent variable: distance

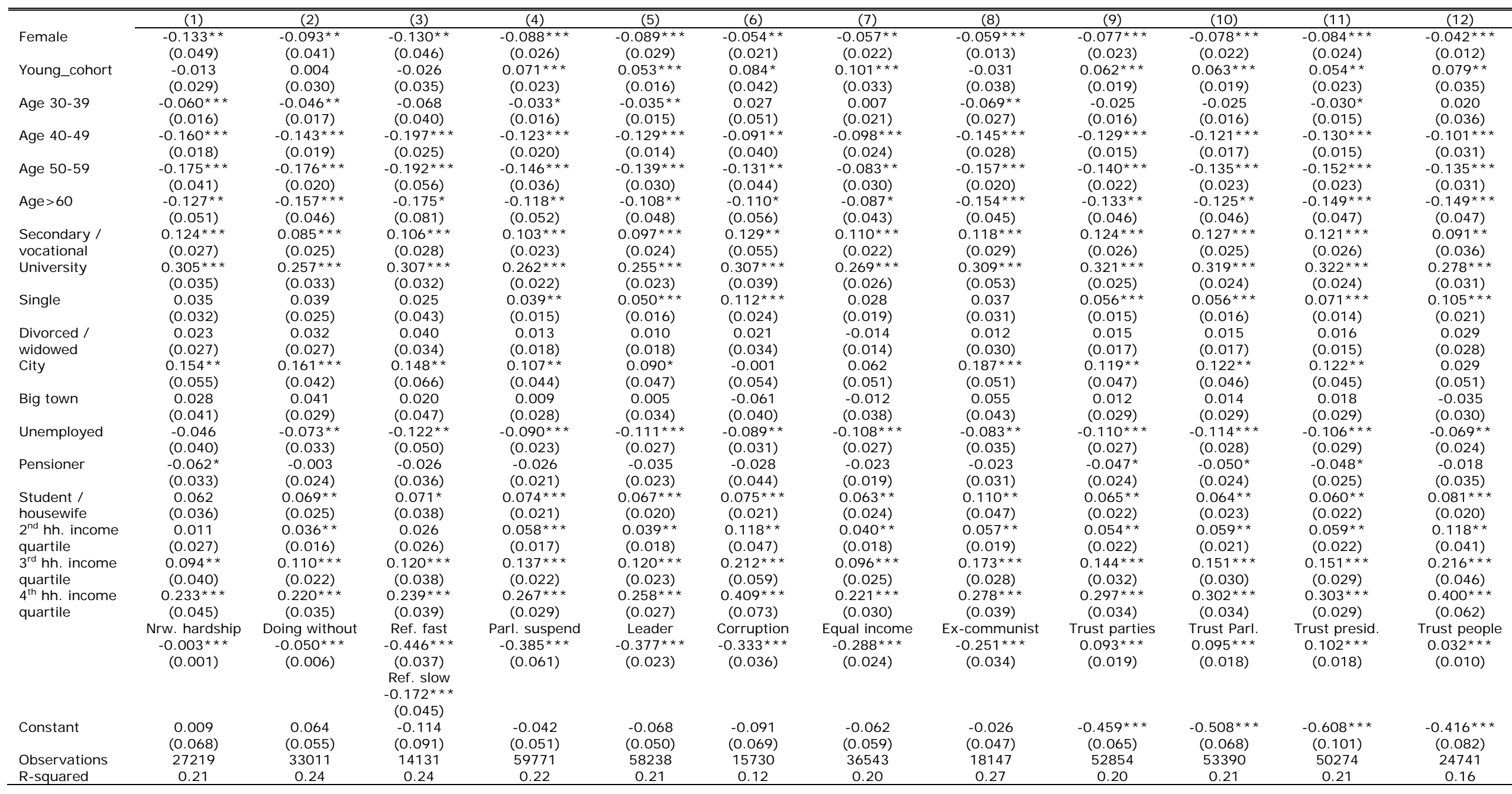

Notes: Estimation method: OLS. Standard errors clustered by country are in parentheses. * significant at 10 percent; ** significant at 5 percent; $* * *$ significant at 1

percent. For variables definitions, see text and Data Appendix. Additional controls include country and year dummies interactions. 
Table 10. Determinants of support - present versus past by country: Economic system

\begin{tabular}{|c|c|c|c|c|c|c|c|c|c|c|c|c|c|c|}
\hline & $\begin{array}{c}(1) \\
\text { Czech } \\
\text { Republic }\end{array}$ & $\begin{array}{c}(2) \\
\text { Slovakia }\end{array}$ & $\begin{array}{c}(3) \\
\text { Hungary }\end{array}$ & $\begin{array}{c}(4) \\
\text { Poland }\end{array}$ & $\begin{array}{c}(5) \\
\text { Slovenia }\end{array}$ & $\begin{array}{c}(6) \\
\text { Estonia }\end{array}$ & $\begin{array}{c}\text { (7) } \\
\text { Latvia }\end{array}$ & $\begin{array}{c}(8) \\
\text { Lithuania }\end{array}$ & $\begin{array}{c}\text { (9) } \\
\text { Bulgaria }\end{array}$ & $\begin{array}{c}(10) \\
\text { Romania }\end{array}$ & $\begin{array}{c}(11) \\
\text { Croatia }\end{array}$ & $\begin{array}{c}\text { (12) } \\
\text { Russia }\end{array}$ & $\begin{array}{c}\text { (13) } \\
\text { Ukraine }\end{array}$ & $\begin{array}{c}\text { (14) } \\
\text { Belarus }\end{array}$ \\
\hline Female & $\begin{array}{c}0.038 \\
(0.031)\end{array}$ & $\begin{array}{l}-0.032 \\
(0.032)\end{array}$ & $\begin{array}{c}-0.076 * * \\
(0.032)\end{array}$ & $\begin{array}{l}-0.035 \\
(0.029)\end{array}$ & $\begin{array}{c}-0.117 * * * \\
(0.034)\end{array}$ & $\begin{array}{c}-0.389 * * * \\
(0.028)\end{array}$ & $\begin{array}{c}-0.490 * * * \\
(0.029)\end{array}$ & $\begin{array}{c}-0.440 * * * \\
(0.024)\end{array}$ & $\begin{array}{c}-0.062^{* *} \\
(0.025)\end{array}$ & $\begin{array}{c}0.008 \\
(0.033)\end{array}$ & $\begin{array}{c}-0.062 \\
(0.046)\end{array}$ & $\begin{array}{c}-0.038 * * \\
(0.017)\end{array}$ & $\begin{array}{l}-0.045 \\
(0.030)\end{array}$ & $\begin{array}{c}-0.020 \\
(0.035)\end{array}$ \\
\hline Young_cohort & $\begin{array}{c}0.072 \\
(0.068)\end{array}$ & $\begin{array}{c}0.085 \\
(0.072)\end{array}$ & $\begin{array}{c}-0.135^{*} \\
(0.071)\end{array}$ & $\begin{array}{l}-0.097 \\
(0.066)\end{array}$ & $\begin{array}{c}0.102 \\
(0.083)\end{array}$ & $\begin{array}{c}0.070 \\
(0.058)\end{array}$ & $\begin{array}{c}0.113 \\
(0.069)\end{array}$ & $\begin{array}{c}0.066 \\
(0.059)\end{array}$ & $\begin{array}{c}0.099 * \\
(0.058)\end{array}$ & $\begin{array}{c}0.116 \\
(0.071)\end{array}$ & $\begin{array}{l}-0.007 \\
(0.119)\end{array}$ & $\begin{array}{c}0.130 * * * \\
(0.035)\end{array}$ & $\begin{array}{c}0.010 \\
(0.064)\end{array}$ & $\begin{array}{c}0.006 \\
(0.082)\end{array}$ \\
\hline Age 30-39 & $\begin{array}{c}-0.117 * * \\
(0.057)\end{array}$ & $\begin{array}{c}0.061 \\
(0.061)\end{array}$ & $\begin{array}{c}-0.078 \\
(0.057)\end{array}$ & $\begin{array}{c}-0.055 \\
(0.053)\end{array}$ & $\begin{array}{l}-0.005 \\
(0.070)\end{array}$ & $\begin{array}{c}-0.152 * * * \\
(0.047)\end{array}$ & $\begin{array}{c}-0.029 \\
(0.055)\end{array}$ & $\begin{array}{c}-0.078 \\
(0.049)\end{array}$ & $\begin{array}{c}-0.016 \\
(0.053)\end{array}$ & $\begin{array}{c}0.048 \\
(0.060)\end{array}$ & $\begin{array}{c}0.062 \\
(0.075)\end{array}$ & $\begin{array}{c}-0.057 * \\
(0.031)\end{array}$ & $\begin{array}{c}-0.022 \\
(0.058)\end{array}$ & $\begin{array}{l}-0.058 \\
(0.071)\end{array}$ \\
\hline Age $40-49$ & $\begin{array}{c}-0.197 * * * \\
(0.057)\end{array}$ & $\begin{array}{c}-0.115^{*} \\
(0.064)\end{array}$ & $\begin{array}{c}-0.236 * * * \\
(0.059)\end{array}$ & $\begin{array}{c}-0.188 * * * \\
(0.056)\end{array}$ & $\begin{array}{l}-0.059 \\
(0.075)\end{array}$ & $\begin{array}{c}-0.320 * * * \\
(0.050)\end{array}$ & $\begin{array}{c}-0.163^{* * *} * \\
(0.057)\end{array}$ & $\begin{array}{c}-0.139 * * * \\
(0.051)\end{array}$ & $\begin{array}{c}-0.181^{* * *} \\
(0.054)\end{array}$ & $\begin{array}{l}-0.020 \\
(0.063)\end{array}$ & $\begin{array}{c}0.020 \\
(0.078)\end{array}$ & $\begin{array}{c}-0.117 * * * \\
(0.033)\end{array}$ & $\begin{array}{c}-0.198^{* * *} \\
(0.059)\end{array}$ & $\begin{array}{c}-0.197 * * * \\
(0.069)\end{array}$ \\
\hline Age 50-59 & $\begin{array}{c}-0.285^{* * *} * \\
(0.063)\end{array}$ & $\begin{array}{l}-0.027 \\
(0.071)\end{array}$ & $\begin{array}{c}-0.217 * * * \\
(0.066)\end{array}$ & $\begin{array}{c}-0.258^{* * *} \\
(0.065)\end{array}$ & $\begin{array}{l}-0.014 \\
(0.074)\end{array}$ & $\begin{array}{c}-0.348 * * * \\
(0.052)\end{array}$ & $\begin{array}{c}-0.161 * * * \\
(0.060)\end{array}$ & $\begin{array}{c}-0.155^{* * *} \\
(0.053)\end{array}$ & $\begin{array}{c}-0.166 * * * \\
(0.055)\end{array}$ & $\begin{array}{l}-0.035 \\
(0.066)\end{array}$ & $\begin{array}{l}-0.028 \\
(0.087)\end{array}$ & $\begin{array}{c}-0.221 * * * \\
(0.035)\end{array}$ & $\begin{array}{c}-0.154 * * \\
(0.063)\end{array}$ & $\begin{array}{c}-0.274 * * * \\
(0.076)\end{array}$ \\
\hline Age $>60$ & $\begin{array}{c}-0.157^{*} \\
(0.084)\end{array}$ & $\begin{array}{c}0.014 \\
(0.084)\end{array}$ & $\begin{array}{l}-0.128 \\
(0.078)\end{array}$ & $\begin{array}{c}-0.083 \\
(0.071)\end{array}$ & $\begin{array}{c}0.089 \\
(0.069)\end{array}$ & $\begin{array}{c}-0.423 * * * \\
(0.061)\end{array}$ & $\begin{array}{c}-0.113 \\
(0.070)\end{array}$ & $\begin{array}{c}-0.014 \\
(0.065)\end{array}$ & $\begin{array}{c}-0.191 * * * \\
(0.063)\end{array}$ & $\begin{array}{l}0.134 * \\
(0.073)\end{array}$ & $\begin{array}{c}0.171 \\
(0.110)\end{array}$ & $\begin{array}{c}-0.287 * * * \\
(0.042)\end{array}$ & $\begin{array}{c}-0.167 * * \\
(0.068)\end{array}$ & $\begin{array}{c}-0.236 * * \\
(0.092)\end{array}$ \\
\hline $\begin{array}{l}\text { Secondary / } \\
\text { vocational }\end{array}$ & $\begin{array}{c}0.162 * * * \\
(0.043)\end{array}$ & $\begin{array}{c}0.116 * * * \\
(0.043)\end{array}$ & $\begin{array}{c}0.125 * * * \\
(0.038)\end{array}$ & $\begin{array}{c}0.132 * * * \\
(0.037)\end{array}$ & $\begin{array}{c}0.028 \\
(0.040)\end{array}$ & $\begin{array}{c}0.052 \\
(0.035)\end{array}$ & $\begin{array}{c}0.049 \\
(0.041)\end{array}$ & $\begin{array}{c}-0.029 \\
(0.034)\end{array}$ & $\begin{array}{c}0.219 * * * \\
(0.032)\end{array}$ & $\begin{array}{c}-0.029 \\
(0.043)\end{array}$ & $\begin{array}{c}0.013 \\
(0.060)\end{array}$ & $\begin{array}{c}0.074 * * * \\
(0.025)\end{array}$ & $\begin{array}{c}-0.006 \\
(0.041)\end{array}$ & $\begin{array}{c}-0.004 \\
(0.048)\end{array}$ \\
\hline University & $\begin{array}{c}0.356 * * * \\
(0.060)\end{array}$ & $\begin{array}{c}0.216 * * * \\
(0.063)\end{array}$ & $\begin{array}{c}0.467 * * * \\
(0.055)\end{array}$ & $\begin{array}{c}0.472 * * * \\
(0.056)\end{array}$ & $\begin{array}{c}0.266 * * * \\
(0.055)\end{array}$ & $\begin{array}{c}0.215 * * * \\
(0.042)\end{array}$ & $\begin{array}{c}0.257^{* * *} \\
(0.049)\end{array}$ & $\begin{array}{c}0.299 * * * \\
(0.042)\end{array}$ & $\begin{array}{c}0.282 * * * \\
(0.046)\end{array}$ & $\begin{array}{c}0.062 \\
(0.064)\end{array}$ & $\begin{array}{c}0.034 \\
(0.074)\end{array}$ & $\begin{array}{c}0.260 * * * \\
(0.029)\end{array}$ & $\begin{array}{l}0.124 * * \\
(0.051)\end{array}$ & $\begin{array}{c}-0.107^{*} \\
(0.063)\end{array}$ \\
\hline Single & $\begin{array}{c}-0.046 \\
(0.055)\end{array}$ & $\begin{array}{c}0.049 \\
(0.054)\end{array}$ & $\begin{array}{c}0.059 \\
(0.056)\end{array}$ & $\begin{array}{c}0.136 * * * \\
(0.046)\end{array}$ & $\begin{array}{c}0.176 * * * \\
(0.046)\end{array}$ & $\begin{array}{c}-0.009 \\
(0.040)\end{array}$ & $\begin{array}{l}0.091 * \\
(0.048)\end{array}$ & $\begin{array}{c}0.120 * * * \\
(0.043)\end{array}$ & $\begin{array}{c}0.095 * * \\
(0.037)\end{array}$ & $\begin{array}{c}0.133 * * \\
(0.054)\end{array}$ & $\begin{array}{c}0.028 \\
(0.071)\end{array}$ & $\begin{array}{c}0.098 * * * \\
(0.027)\end{array}$ & $\begin{array}{c}0.137 * * * \\
(0.052)\end{array}$ & $\begin{array}{c}0.040 \\
(0.066)\end{array}$ \\
\hline $\begin{array}{l}\text { Divorced / } \\
\text { widowed }\end{array}$ & $\begin{array}{c}0.033 \\
(0.049)\end{array}$ & $\begin{array}{c}-0.020 \\
(0.051)\end{array}$ & $\begin{array}{c}0.024 \\
(0.046)\end{array}$ & $\begin{array}{l}-0.018 \\
(0.045)\end{array}$ & $\begin{array}{c}0.003 \\
(0.057)\end{array}$ & $\begin{array}{c}0.024 \\
(0.035)\end{array}$ & $\begin{array}{c}-0.063 * \\
(0.037)\end{array}$ & $\begin{array}{c}0.004 \\
(0.032)\end{array}$ & $\begin{array}{c}0.090 * * \\
(0.036)\end{array}$ & $\begin{array}{c}0.111 * * \\
(0.052)\end{array}$ & $\begin{array}{c}-0.064 \\
(0.073)\end{array}$ & $\begin{array}{c}0.053^{* *} \\
(0.023)\end{array}$ & $\begin{array}{c}-0.040 \\
(0.038)\end{array}$ & $\begin{array}{c}-0.026 \\
(0.047)\end{array}$ \\
\hline City & $\begin{array}{c}0.247 * * * \\
(0.043)\end{array}$ & $\begin{array}{c}0.367 * * * \\
(0.051)\end{array}$ & $\begin{array}{c}0.156 * * * \\
(0.044)\end{array}$ & $\begin{array}{c}0.210 * * * \\
(0.036)\end{array}$ & $\begin{array}{c}0.025 \\
(0.051)\end{array}$ & $\begin{array}{c}0.155^{* * *} * \\
(0.034)\end{array}$ & $\begin{array}{l}0.065^{*} \\
(0.037)\end{array}$ & $\begin{array}{c}0.196 * * * \\
(0.032)\end{array}$ & $\begin{array}{c}0.241 * * * \\
(0.034)\end{array}$ & $\begin{array}{c}0.016 \\
(0.044)\end{array}$ & $\begin{array}{c}-0.007 \\
(0.060)\end{array}$ & $\begin{array}{c}0.231 * * * \\
(0.024)\end{array}$ & $\begin{array}{c}0.040 \\
(0.037)\end{array}$ & $\begin{array}{c}-0.052 \\
(0.045)\end{array}$ \\
\hline Big town & $\begin{array}{c}0.166 * * * \\
(0.034)\end{array}$ & $\begin{array}{c}0.022 \\
(0.034)\end{array}$ & $\begin{array}{c}0.026 \\
(0.036)\end{array}$ & $\begin{array}{c}0.119 * * * \\
(0.036)\end{array}$ & $\begin{array}{l}-0.026 \\
(0.036)\end{array}$ & $\begin{array}{c}0.079 * * \\
(0.033)\end{array}$ & $\begin{array}{c}0.010 \\
(0.036)\end{array}$ & $\begin{array}{c}0.097 * * * \\
(0.030)\end{array}$ & $\begin{array}{l}-0.011 \\
(0.032)\end{array}$ & $\begin{array}{c}-0.062 \\
(0.040)\end{array}$ & $\begin{array}{c}0.064 \\
(0.054)\end{array}$ & $\begin{array}{l}0.033^{*} \\
(0.020)\end{array}$ & $\begin{array}{c}-0.082 * * \\
(0.036)\end{array}$ & $\begin{array}{c}0.019 \\
(0.044)\end{array}$ \\
\hline Unemployed & $\begin{array}{c}-0.168 * * \\
(0.083)\end{array}$ & $\begin{array}{c}-0.177 * * * \\
(0.056)\end{array}$ & $\begin{array}{c}-0.102 * \\
(0.061)\end{array}$ & $\begin{array}{c}-0.160 * * * \\
(0.052)\end{array}$ & $\begin{array}{c}-0.211 * * * \\
(0.062)\end{array}$ & $\begin{array}{c}-0.157 * * * \\
(0.050)\end{array}$ & $\begin{array}{c}-0.139 * * * \\
(0.049)\end{array}$ & $\begin{array}{c}-0.155^{* * *} \\
(0.041)\end{array}$ & $\begin{array}{c}-0.090 * * \\
(0.039)\end{array}$ & $\begin{array}{c}-0.251 * * * \\
(0.063)\end{array}$ & $\begin{array}{c}-0.312 * * * \\
(0.092)\end{array}$ & $\begin{array}{c}-0.024 \\
(0.035)\end{array}$ & $\begin{array}{c}-0.233^{* * *} \\
(0.052)\end{array}$ & $\begin{array}{c}0.025 \\
(0.086)\end{array}$ \\
\hline Pensioner & $\begin{array}{c}-0.099 \\
(0.065)\end{array}$ & $\begin{array}{l}-0.106 \\
(0.066)\end{array}$ & $\begin{array}{c}0.063 \\
(0.056)\end{array}$ & $\begin{array}{c}-0.015 \\
(0.053)\end{array}$ & $\begin{array}{c}-0.042 \\
(0.046)\end{array}$ & $\begin{array}{c}-0.086^{*} \\
(0.045)\end{array}$ & $\begin{array}{c}-0.018 \\
(0.053)\end{array}$ & $\begin{array}{c}0.061 \\
(0.047)\end{array}$ & $\begin{array}{c}-0.066 \\
(0.046)\end{array}$ & $\begin{array}{c}-0.041 \\
(0.057)\end{array}$ & $\begin{array}{c}-0.164 * \\
(0.095)\end{array}$ & $\begin{array}{l}0.058^{*} \\
(0.031)\end{array}$ & $\begin{array}{c}-0.120 * * * \\
(0.045)\end{array}$ & $\begin{array}{l}-0.057 \\
(0.072)\end{array}$ \\
\hline $\begin{array}{l}\text { Student / } \\
\text { housewife }\end{array}$ & $\begin{array}{c}0.078 \\
(0.078)\end{array}$ & $\begin{array}{c}0.243^{* * *} \\
(0.081)\end{array}$ & $\begin{array}{l}0.133^{*} \\
(0.069)\end{array}$ & $\begin{array}{l}0.096^{*} \\
(0.052)\end{array}$ & $\begin{array}{l}0.135 * * \\
(0.055)\end{array}$ & $\begin{array}{c}0.061 \\
(0.051)\end{array}$ & $\begin{array}{l}-0.053 \\
(0.057)\end{array}$ & $\begin{array}{c}0.010 \\
(0.044)\end{array}$ & $\begin{array}{c}0.031 \\
(0.062)\end{array}$ & $\begin{array}{c}0.096 \\
(0.059)\end{array}$ & $\begin{array}{l}-0.031 \\
(0.077)\end{array}$ & $\begin{array}{l}0.067 * * \\
(0.032)\end{array}$ & $\begin{array}{c}0.046 \\
(0.056)\end{array}$ & $\begin{array}{c}0.235 * * * \\
(0.085)\end{array}$ \\
\hline $\begin{array}{l}\text { 2nd hh. inc. } \\
\text { Quartile }\end{array}$ & $\begin{array}{c}0.044 \\
(0.048)\end{array}$ & $\begin{array}{c}0.027 \\
(0.050)\end{array}$ & $\begin{array}{l}0.089 * \\
(0.047)\end{array}$ & $\begin{array}{l}0.103^{* *} \\
(0.041)\end{array}$ & $\begin{array}{c}-0.059 \\
(0.049)\end{array}$ & $\begin{array}{c}-0.102 * * * \\
(0.036)\end{array}$ & $\begin{array}{c}-0.006 \\
(0.039)\end{array}$ & $\begin{array}{l}-0.006 \\
(0.033)\end{array}$ & $\begin{array}{c}0.053 \\
(0.036)\end{array}$ & $\begin{array}{l}0.124 * * \\
(0.051)\end{array}$ & $\begin{array}{c}0.018 \\
(0.060)\end{array}$ & $\begin{array}{c}0.081 * * * \\
(0.023)\end{array}$ & $\begin{array}{c}0.017 \\
(0.040)\end{array}$ & $\begin{array}{c}0.022 \\
(0.049)\end{array}$ \\
\hline $\begin{array}{l}\text { 3rd hh. inc. } \\
\text { Quartile }\end{array}$ & $\begin{array}{c}0.177 * * * \\
(0.051)\end{array}$ & $\begin{array}{l}0.084 * \\
(0.050)\end{array}$ & $\begin{array}{c}0.145 * * * \\
(0.050)\end{array}$ & $\begin{array}{c}0.137 * * * \\
(0.041)\end{array}$ & $\begin{array}{l}0.089^{*} \\
(0.051)\end{array}$ & $\begin{array}{c}-0.049 \\
(0.036)\end{array}$ & $\begin{array}{c}-0.009 \\
(0.040)\end{array}$ & $\begin{array}{c}0.043 \\
(0.033)\end{array}$ & $\begin{array}{c}0.144 * * * \\
(0.039)\end{array}$ & $\begin{array}{c}0.225 * * * \\
(0.054)\end{array}$ & $\begin{array}{c}-0.060 \\
(0.065)\end{array}$ & $\begin{array}{c}0.187 * * * \\
(0.025)\end{array}$ & $\begin{array}{c}0.104 * * \\
(0.042)\end{array}$ & $\begin{array}{c}0.101^{*} \\
(0.052)\end{array}$ \\
\hline $\begin{array}{l}\text { 4th hh. inc. } \\
\text { quartile } \\
1991\end{array}$ & $\begin{array}{c}0.330 * * * \\
(0.053) \\
0.053 \\
(0.057)\end{array}$ & $\begin{array}{c}0.341 * * * \\
(0.052) \\
0.090 \\
(0.070)\end{array}$ & $\begin{array}{c}0.347 * * * \\
(0.052) \\
-0.060 \\
(0.059)\end{array}$ & $\begin{array}{c}0.221 * * * \\
(0.045) \\
0.090 * \\
(0.053)\end{array}$ & $\begin{array}{c}0.171 * * * \\
(0.053) \\
-0.163^{* * *} \\
(0.053)\end{array}$ & $\begin{array}{c}0.180 * * * \\
(0.036)\end{array}$ & $\begin{array}{c}0.270 * * * \\
(0.041)\end{array}$ & $\begin{array}{c}0.343^{* * *} * \\
(0.037)\end{array}$ & $\begin{array}{c}0.317^{* * *} \\
(0.043) \\
0.415^{* * *} \\
(0.045)\end{array}$ & $\begin{array}{c}0.263^{* * *} * \\
(0.057) \\
0.310 * * * \\
(0.051)\end{array}$ & $\begin{array}{c}0.059 \\
(0.066)\end{array}$ & $\begin{array}{c}0.414 * * * \\
(0.026)\end{array}$ & $\begin{array}{c}0.220 * * * \\
(0.043)\end{array}$ & $\begin{array}{c}0.236 * * * \\
(0.057)\end{array}$ \\
\hline 1992 & $\begin{array}{c}-0.072 \\
(0.048)\end{array}$ & $(0.056)$ & $\begin{array}{c}-0.274 * * * \\
(0.062)\end{array}$ & $\begin{array}{l}-0.040 \\
(0.053)\end{array}$ & & & & & & $\begin{array}{l}0.088^{*} \\
(0.050)\end{array}$ & $\begin{array}{l}-0.030 \\
(0.053)\end{array}$ & $\begin{array}{c}-0.299 * * * \\
(0.034)\end{array}$ & $\begin{array}{c}-1.046 * * * \\
(0.052)\end{array}$ & \\
\hline 1993 & $\begin{array}{l}0.120 * * \\
(0.048)\end{array}$ & $\begin{array}{c}-0.234 * * * \\
(0.057)\end{array}$ & $\begin{array}{c}-0.272 * * * \\
(0.058)\end{array}$ & $\begin{array}{c}0.178 * * * \\
(0.053)\end{array}$ & $\begin{array}{c}0.323 * * * \\
(0.053)\end{array}$ & $\begin{array}{c}-0.422 * * * \\
(0.045)\end{array}$ & $\begin{array}{c}0.261 * * * \\
(0.041)\end{array}$ & $\begin{array}{c}-0.855^{* * *} * \\
(0.041)\end{array}$ & $\begin{array}{c}-0.162 * * * \\
(0.044)\end{array}$ & & & $\begin{array}{c}-0.008 \\
(0.033)\end{array}$ & $\begin{array}{c}-0.723 * * * \\
(0.045)\end{array}$ & $\begin{array}{c}-1.178 * * * \\
(0.054)\end{array}$ \\
\hline 1995 & $\begin{array}{c}0.147 * * * \\
(0.050)\end{array}$ & $\begin{array}{c}-0.033 \\
(0.047)\end{array}$ & $\begin{array}{c}-0.280 * * * \\
(0.056)\end{array}$ & $\begin{array}{c}0.691 * * * \\
(0.052)\end{array}$ & $\begin{array}{c}0.295 * * * \\
(0.056)\end{array}$ & $\begin{array}{c}-0.387 * * * \\
(0.047) \\
-0.225 * * *\end{array}$ & $\begin{array}{c}0.300 * * * \\
(0.046)\end{array}$ & $\begin{array}{c}-1.071 * * * \\
(0.046) \\
-0.827 * * *\end{array}$ & $\begin{array}{c}-0.230 * * * \\
(0.044)\end{array}$ & & & $\begin{array}{c}-0.374 * * * \\
(0.033) \\
-0.041\end{array}$ & $\begin{array}{c}-1.043 * * * \\
(0.043)\end{array}$ & $\begin{array}{c}-1.291 * * * \\
(0.053)\end{array}$ \\
\hline
\end{tabular}




\begin{tabular}{|c|c|c|c|c|c|c|c|c|c|c|c|c|c|c|}
\hline & & & & & & $(0.048)$ & & $(0.044)$ & & & & $(0.031)$ & & \\
\hline 1998 & & $\begin{array}{l}-0.037 \\
(0.049)\end{array}$ & & & $\begin{array}{l}-0.062 \\
(0.056)\end{array}$ & & & & $\begin{array}{c}0.284 * * * \\
(0.045)\end{array}$ & $\begin{array}{c}0.202 * * * \\
(0.049)\end{array}$ & & $\begin{array}{c}-0.198 * * * \\
(0.034)\end{array}$ & $\begin{array}{c}-1.175 * * * \\
(0.044)\end{array}$ & $\begin{array}{c}-0.689 * * * \\
(0.054)\end{array}$ \\
\hline 2000 & & & & & & $\begin{array}{l}-0.013 \\
(0.052)\end{array}$ & $\begin{array}{c}0.169 * * * \\
(0.048)\end{array}$ & $\begin{array}{c}-0.878 * * * \\
(0.043)\end{array}$ & & & & $\begin{array}{c}-0.317 * * * \\
(0.033)\end{array}$ & & \\
\hline 2001 & & & $\begin{array}{c}0.330 * * * \\
(0.058)\end{array}$ & $\begin{array}{c}0.048 \\
(0.055)\end{array}$ & & $\begin{array}{c}0.042 \\
(0.049)\end{array}$ & $\begin{array}{c}0.739 * * * \\
(0.049)\end{array}$ & $\begin{array}{c}-0.395^{* * *} \\
(0.042)\end{array}$ & $\begin{array}{c}0.441 * * * \\
(0.040)\end{array}$ & & & $\begin{array}{c}0.044 \\
(0.032)\end{array}$ & & \\
\hline Minority & & & & & & $\begin{array}{c}-0.630 * * * \\
(0.027)\end{array}$ & $\begin{array}{c}-0.299 * * * \\
(0.030)\end{array}$ & $\begin{array}{c}-0.146 * * * \\
(0.027)\end{array}$ & & & & & & \\
\hline Constant & $\begin{array}{c}-0.042 \\
(0.090)\end{array}$ & $\begin{array}{c}-0.696 * * * \\
(0.092)\end{array}$ & $\begin{array}{c}-0.679 * * * \\
(0.090)\end{array}$ & $\begin{array}{c}-0.496 * * * \\
(0.080)\end{array}$ & $\begin{array}{c}-0.376 * * * \\
(0.092)\end{array}$ & $\begin{array}{c}0.539 * * * \\
(0.070)\end{array}$ & $\begin{array}{c}-0.761^{* * *} \\
(0.073)\end{array}$ & $\begin{array}{l}-0.130 * \\
(0.072)\end{array}$ & $\begin{array}{c}-0.875 * * * \\
(0.074)\end{array}$ & $\begin{array}{c}-0.657 * * * \\
(0.087)\end{array}$ & $\begin{array}{l}-0.058 \\
(0.092)\end{array}$ & $\begin{array}{c}-0.988^{* * *} \\
(0.050)\end{array}$ & $\begin{array}{c}-0.502 * * * \\
(0.079)\end{array}$ & $\begin{array}{l}-0.051 \\
(0.097)\end{array}$ \\
\hline Observations & 4386 & 3801 & 4168 & 4704 & 3639 & 5494 & 4310 & 6317 & 5952 & 3740 & 1971 & 14661 & 4653 & 3434 \\
\hline R-squared & 0.07 & 0.08 & 0.11 & 0.13 & 0.08 & 0.25 & 0.19 & 0.22 & 0.16 & 0.04 & 0.01 & 0.11 & 0.24 & 0.21 \\
\hline
\end{tabular}
definitions are as in Table 3. 
Table 11. Determinants of support - present versus past by country: Political system

\begin{tabular}{|c|c|c|c|c|c|c|c|c|c|c|c|c|c|c|}
\hline & $\begin{array}{c}\text { (1) } \\
\text { Czech } \\
\text { Republic }\end{array}$ & $\begin{array}{c}(2) \\
\text { Slovakia }\end{array}$ & $\begin{array}{c}\text { (3) } \\
\text { Hungary }\end{array}$ & $\begin{array}{c}(4) \\
\text { Poland }\end{array}$ & $\begin{array}{c}(5) \\
\text { Slovenia }\end{array}$ & $\begin{array}{c}6) \\
\text { Estonia }\end{array}$ & $\begin{array}{c}7) \\
\text { Latvia }\end{array}$ & $\begin{array}{c}(8) \\
\text { Lithuania }\end{array}$ & $\begin{array}{c}\text { (9) } \\
\text { Bulgaria }\end{array}$ & $\begin{array}{c}(10) \\
\text { Romania }\end{array}$ & $\begin{array}{c}(11) \\
\text { Croatia }\end{array}$ & $\begin{array}{c}\text { (12) } \\
\text { Russia }\end{array}$ & $\begin{array}{c}\text { (13) } \\
\text { Ukraine }\end{array}$ & $\begin{array}{c}(14) \\
\text { Belarus }\end{array}$ \\
\hline Female & $\begin{array}{c}0.026 \\
(0.031)\end{array}$ & $\begin{array}{c}-0.040 \\
(0.032)\end{array}$ & $\begin{array}{l}-0.053 \\
(0.033)\end{array}$ & $\begin{array}{c}-0.078 * * * \\
(0.030)\end{array}$ & $\begin{array}{c}-0.073^{* *} \\
(0.034)\end{array}$ & $\begin{array}{c}-0.324 * * * \\
(0.029)\end{array}$ & $\begin{array}{c}-0.254 * * * \\
(0.033)\end{array}$ & $\begin{array}{c}-0.258 * * * \\
(0.026)\end{array}$ & $\begin{array}{c}-0.081 * * * \\
(0.025)\end{array}$ & $(0.033)$ & $\begin{array}{c}-0.001 \\
(0.046)\end{array}$ & $\begin{array}{l}-0.010 \\
(0.017)\end{array}$ & $\begin{array}{c}-0.040 \\
(0.030)\end{array}$ & $\begin{array}{c}-0.056 \\
(0.035)\end{array}$ \\
\hline Young_cohort & $\begin{array}{c}0.049 \\
(0.068)\end{array}$ & $\begin{array}{c}-0.091 \\
(0.069)\end{array}$ & $\begin{array}{l}-0.009 \\
(0.075)\end{array}$ & $\begin{array}{l}-0.010 \\
(0.064)\end{array}$ & $\begin{array}{c}-0.016 \\
(0.081)\end{array}$ & $\begin{array}{c}0.133^{* *} \\
(0.055)\end{array}$ & $\begin{array}{c}0.092 \\
(0.071)\end{array}$ & $\begin{array}{c}0.130 * * \\
(0.057)\end{array}$ & $\begin{array}{c}0.004 \\
(0.056)\end{array}$ & $\begin{array}{c}0.051 \\
(0.072)\end{array}$ & $\begin{array}{c}0.228 * * \\
(0.104)\end{array}$ & $\begin{array}{c}0.056 \\
(0.034)\end{array}$ & $\begin{array}{c}0.035 \\
(0.060)\end{array}$ & $\begin{array}{c}-0.024 \\
(0.081)\end{array}$ \\
\hline Age $30-39$ & $\begin{array}{l}-0.061 \\
(0.056)\end{array}$ & $\begin{array}{c}0.033 \\
(0.060)\end{array}$ & $\begin{array}{l}-0.016 \\
(0.060)\end{array}$ & $\begin{array}{c}-0.036 \\
(0.054)\end{array}$ & $\begin{array}{c}-0.061 \\
(0.069)\end{array}$ & $\begin{array}{c}-0.075 \\
(0.046)\end{array}$ & $\begin{array}{c}0.042 \\
(0.057)\end{array}$ & $\begin{array}{c}0.047 \\
(0.049)\end{array}$ & $\begin{array}{c}-0.098^{*} \\
(0.051)\end{array}$ & $\begin{array}{c}0.047 \\
(0.060)\end{array}$ & $\begin{array}{c}0.020 \\
(0.076)\end{array}$ & $\begin{array}{c}-0.054 * \\
(0.031)\end{array}$ & $\begin{array}{c}-0.053 \\
(0.053)\end{array}$ & $\begin{array}{c}-0.123^{*} \\
(0.070)\end{array}$ \\
\hline Age $40-49$ & $\begin{array}{l}-0.050 \\
(0.056)\end{array}$ & $\begin{array}{c}-0.157 * * \\
(0.062)\end{array}$ & $\begin{array}{c}-0.114 * \\
(0.062)\end{array}$ & $\begin{array}{c}-0.150 * * * \\
(0.058)\end{array}$ & $\begin{array}{c}-0.213 * * * \\
(0.073)\end{array}$ & $\begin{array}{c}-0.170 * * * \\
(0.049)\end{array}$ & $\begin{array}{l}-0.026 \\
(0.059)\end{array}$ & $\begin{array}{c}-0.061 \\
(0.050)\end{array}$ & $\begin{array}{c}-0.203 * * * \\
(0.052)\end{array}$ & $\begin{array}{l}-0.050 \\
(0.063)\end{array}$ & $\begin{array}{c}0.071 \\
(0.076)\end{array}$ & $\begin{array}{c}-0.167 * * * \\
(0.032)\end{array}$ & $\begin{array}{c}-0.163^{* * *} \\
(0.058)\end{array}$ & $\begin{array}{c}-0.160 * * \\
(0.071)\end{array}$ \\
\hline Age 50-59 & $\begin{array}{c}-0.129 * * \\
(0.063)\end{array}$ & $\begin{array}{c}-0.061 \\
(0.069)\end{array}$ & $\begin{array}{c}-0.042 \\
(0.069)\end{array}$ & $\begin{array}{c}-0.161 * * \\
(0.066)\end{array}$ & $\begin{array}{c}-0.180 * * \\
(0.071)\end{array}$ & $\begin{array}{c}-0.184 * * * \\
(0.052)\end{array}$ & $\begin{array}{c}0.031 \\
(0.063)\end{array}$ & $\begin{array}{c}-0.089 * \\
(0.053)\end{array}$ & $\begin{array}{c}-0.237 * * * \\
(0.055)\end{array}$ & $\begin{array}{c}-0.144 * * \\
(0.067)\end{array}$ & $\begin{array}{c}0.088 \\
(0.084)\end{array}$ & $\begin{array}{c}-0.257 * * * \\
(0.035)\end{array}$ & $\begin{array}{c}-0.227^{* * *} \\
(0.061)\end{array}$ & $\begin{array}{c}-0.210 * * * \\
(0.078)\end{array}$ \\
\hline Age $>60$ & $\begin{array}{l}-0.023 \\
(0.083)\end{array}$ & $\begin{array}{c}-0.073 \\
(0.084)\end{array}$ & $\begin{array}{c}0.132 \\
(0.082)\end{array}$ & $\begin{array}{c}-0.124^{*} \\
(0.072)\end{array}$ & $\begin{array}{c}-0.044 \\
(0.066)\end{array}$ & $\begin{array}{c}-0.248 * * * \\
(0.061)\end{array}$ & $\begin{array}{c}0.070 \\
(0.077)\end{array}$ & $\begin{array}{c}0.079 \\
(0.066)\end{array}$ & $\begin{array}{c}-0.250 * * * \\
(0.063)\end{array}$ & $\begin{array}{c}-0.100 \\
(0.073)\end{array}$ & $\begin{array}{c}0.149 \\
(0.114)\end{array}$ & $\begin{array}{c}-0.325 * * * \\
(0.043)\end{array}$ & $\begin{array}{c}-0.252 * * * \\
(0.069)\end{array}$ & $\begin{array}{c}-0.391 * * * \\
(0.093)\end{array}$ \\
\hline $\begin{array}{l}\text { Secondary / } \\
\text { vocational }\end{array}$ & $\begin{array}{c}0.245^{* * *} * \\
(0.043)\end{array}$ & $\begin{array}{c}0.164 * * * \\
(0.043)\end{array}$ & $\begin{array}{c}0.210 * * * \\
(0.039)\end{array}$ & $\begin{array}{c}0.131 * * * \\
(0.037)\end{array}$ & $\begin{array}{c}0.056 \\
(0.040)\end{array}$ & $\begin{array}{c}0.069^{*} \\
(0.036)\end{array}$ & $\begin{array}{c}0.065 \\
(0.047)\end{array}$ & $\begin{array}{c}0.042 \\
(0.037)\end{array}$ & $\begin{array}{c}0.230 * * * \\
(0.033)\end{array}$ & $\begin{array}{c}0.057 \\
(0.042)\end{array}$ & $\begin{array}{c}0.046 \\
(0.060)\end{array}$ & $\begin{array}{c}0.101 * * * \\
(0.025)\end{array}$ & $\begin{array}{c}0.084 * * \\
(0.042)\end{array}$ & $\begin{array}{c}0.042 \\
(0.051)\end{array}$ \\
\hline University & $\begin{array}{c}0.421 * * * \\
(0.061)\end{array}$ & $\begin{array}{c}0.309 * * * \\
(0.064)\end{array}$ & $\begin{array}{c}0.501 * * * \\
(0.055)\end{array}$ & $\begin{array}{c}0.469 * * * \\
(0.057)\end{array}$ & $\begin{array}{c}0.302^{* * *} \\
(0.058)\end{array}$ & $\begin{array}{c}0.247 * * * \\
(0.043)\end{array}$ & $\begin{array}{c}0.204 * * * \\
(0.055)\end{array}$ & $\begin{array}{c}0.395^{* * *} \\
(0.043)\end{array}$ & $\begin{array}{c}0.307 * * * \\
(0.045)\end{array}$ & $\begin{array}{c}0.287 * * * \\
(0.062)\end{array}$ & $\begin{array}{c}-0.013 \\
(0.072)\end{array}$ & $\begin{array}{c}0.284 * * * \\
(0.030)\end{array}$ & $\begin{array}{c}0.293^{* * *} * \\
(0.051)\end{array}$ & $\begin{array}{c}0.037 \\
(0.067)\end{array}$ \\
\hline Single & $\begin{array}{c}0.003 \\
(0.054)\end{array}$ & $\begin{array}{c}0.049 \\
(0.051)\end{array}$ & $\begin{array}{c}0.089 \\
(0.055)\end{array}$ & $\begin{array}{l}0.094 * \\
(0.049)\end{array}$ & $\begin{array}{c}0.085^{*} \\
(0.045)\end{array}$ & $\begin{array}{c}-0.099 * * \\
(0.039)\end{array}$ & $\begin{array}{l}0.093^{*} \\
(0.051)\end{array}$ & $\begin{array}{l}0.073^{*} \\
(0.043)\end{array}$ & $\begin{array}{c}0.041 \\
(0.037)\end{array}$ & $\begin{array}{c}0.105 * \\
(0.055)\end{array}$ & $\begin{array}{c}0.010 \\
(0.071)\end{array}$ & $\begin{array}{c}0.070 * * * \\
(0.027)\end{array}$ & $\begin{array}{l}0.083^{*} \\
(0.050)\end{array}$ & $\begin{array}{c}-0.009 \\
(0.062)\end{array}$ \\
\hline $\begin{array}{l}\text { Divorced / } \\
\text { Widowed }\end{array}$ & $\begin{array}{c}0.006 \\
(0.049)\end{array}$ & $\begin{array}{l}-0.023 \\
(0.053)\end{array}$ & $\begin{array}{c}-0.044 \\
(0.046)\end{array}$ & $\begin{array}{c}-0.023 \\
(0.045)\end{array}$ & $\begin{array}{c}-0.113^{*} \\
(0.059)\end{array}$ & $\begin{array}{l}0.086 * * \\
(0.038)\end{array}$ & $(0.041)$ & $\begin{array}{c}-0.048 \\
(0.035)\end{array}$ & $\begin{array}{l}-0.009 \\
(0.035)\end{array}$ & $\begin{array}{l}-0.039 \\
(0.053)\end{array}$ & $\begin{array}{l}-0.103 \\
(0.068)\end{array}$ & $\begin{array}{c}0.058 * * \\
(0.023)\end{array}$ & $\begin{array}{c}-0.050 \\
(0.039)\end{array}$ & $\begin{array}{l}-0.061 \\
(0.050)\end{array}$ \\
\hline City & $\begin{array}{c}0.271^{* * *} \\
(0.043)\end{array}$ & $\begin{array}{c}0.366 * * * \\
(0.050)\end{array}$ & $\begin{array}{c}0.085^{*} \\
(0.044)\end{array}$ & $\begin{array}{c}0.162 * * * \\
(0.036)\end{array}$ & $\begin{array}{c}0.146 * * * \\
(0.050)\end{array}$ & $\begin{array}{c}0.187^{* * *} \\
(0.035)\end{array}$ & $\begin{array}{c}0.111^{* * *} \\
(0.041)\end{array}$ & $\begin{array}{c}0.331 * * * \\
(0.033)\end{array}$ & $\begin{array}{c}0.209 * * * \\
(0.034)\end{array}$ & $\begin{array}{c}0.038 \\
(0.044)\end{array}$ & $\begin{array}{c}0.046 \\
(0.058)\end{array}$ & $\begin{array}{c}0.183^{* * *} \\
(0.024)\end{array}$ & $\begin{array}{c}-0.195^{* * *} \\
(0.038)\end{array}$ & $\begin{array}{c}0.052 \\
(0.046)\end{array}$ \\
\hline Big town & $\begin{array}{c}0.146 * * * \\
(0.034)\end{array}$ & $\begin{array}{l}0.080 * * \\
(0.034)\end{array}$ & $\begin{array}{c}-0.040 \\
(0.036)\end{array}$ & $\begin{array}{c}0.056 \\
(0.037)\end{array}$ & $\begin{array}{l}-0.015 \\
(0.037)\end{array}$ & $\begin{array}{c}0.038 \\
(0.034)\end{array}$ & $\begin{array}{c}0.094 * * \\
(0.041)\end{array}$ & $\begin{array}{c}0.170 * * * \\
(0.032)\end{array}$ & $\begin{array}{l}-0.030 \\
(0.032)\end{array}$ & $\begin{array}{c}0.085^{* *} \\
(0.041)\end{array}$ & $\begin{array}{c}0.033 \\
(0.055)\end{array}$ & $\begin{array}{c}0.027 \\
(0.020)\end{array}$ & $\begin{array}{c}-0.273^{* * *} \\
(0.037)\end{array}$ & $\begin{array}{c}0.026 \\
(0.045)\end{array}$ \\
\hline Unemployed & $\begin{array}{l}-0.119 \\
(0.086)\end{array}$ & $\begin{array}{l}-0.066 \\
(0.059)\end{array}$ & $\begin{array}{c}-0.103^{*} \\
(0.062)\end{array}$ & $\begin{array}{c}-0.082 \\
(0.052)\end{array}$ & $\begin{array}{c}-0.064 \\
(0.063)\end{array}$ & $\begin{array}{c}-0.082 \\
(0.050)\end{array}$ & $\begin{array}{c}-0.190 * * * \\
(0.051)\end{array}$ & $\begin{array}{c}-0.076^{*} \\
(0.042)\end{array}$ & $\begin{array}{c}-0.111 * * * \\
(0.040)\end{array}$ & $\begin{array}{l}-0.050 \\
(0.064)\end{array}$ & $\begin{array}{c}-0.277 * * * \\
(0.088)\end{array}$ & $\begin{array}{c}-0.003 \\
(0.036)\end{array}$ & $\begin{array}{l}-0.089 \\
(0.055)\end{array}$ & $\begin{array}{c}0.094 \\
(0.085)\end{array}$ \\
\hline Pensioner & $\begin{array}{l}-0.095 \\
(0.065)\end{array}$ & $\begin{array}{l}-0.027 \\
(0.067)\end{array}$ & $\begin{array}{c}-0.029 \\
(0.056)\end{array}$ & $\begin{array}{c}0.058 \\
(0.054)\end{array}$ & $\begin{array}{l}-0.042 \\
(0.046)\end{array}$ & $\begin{array}{c}-0.042 \\
(0.048)\end{array}$ & $\begin{array}{c}-0.026 \\
(0.059)\end{array}$ & $\begin{array}{c}0.094^{*} \\
(0.050)\end{array}$ & $\begin{array}{c}-0.096 * * \\
(0.047)\end{array}$ & $\begin{array}{c}0.126 * * \\
(0.058)\end{array}$ & $\begin{array}{c}-0.194 * \\
(0.099)\end{array}$ & $\begin{array}{c}0.036 \\
(0.032)\end{array}$ & $\begin{array}{c}-0.018 \\
(0.050)\end{array}$ & $\begin{array}{c}0.067 \\
(0.070)\end{array}$ \\
\hline Student / & 0.101 & $0.301 * * *$ & 0.104 & $0.129 * *$ & 0.052 & 0.034 & -0.082 & 0.065 & 0.002 & $0.107^{*}$ & $-0.205 * * *$ & $0.080 * * *$ & 0.035 & $0.284 * * *$ \\
\hline $\begin{array}{l}\text { Housewife } \\
\text { 2nd hh. inc. } \\
\text { Quartile }\end{array}$ & $\begin{array}{c}(0.073) \\
0.031 \\
(0.049)\end{array}$ & $\begin{array}{l}(0.077) \\
0.093^{*} \\
(0.051)\end{array}$ & $\begin{array}{l}(0.070) \\
0.097 * * \\
(0.047)\end{array}$ & $\begin{array}{c}(0.052) \\
0.061 \\
(0.041)\end{array}$ & $\begin{array}{c}(0.058) \\
0.045 \\
(0.049)\end{array}$ & $\begin{array}{c}(0.052) \\
-0.077^{* *} \\
(0.036)\end{array}$ & $\begin{array}{l}(0.067) \\
-0.030 \\
(0.043)\end{array}$ & $\begin{array}{c}(0.046) \\
0.038 \\
(0.035)\end{array}$ & $\begin{array}{c}(0.058) \\
0.126 * * * \\
(0.039)\end{array}$ & $\begin{array}{l}(0.058) \\
0.114 * * \\
(0.050)\end{array}$ & $\begin{array}{c}(0.079) \\
0.075 \\
(0.061)\end{array}$ & $\begin{array}{c}(0.031) \\
0.091^{* * *} \\
(0.024)\end{array}$ & $\begin{array}{c}(0.054) \\
-0.017 \\
(0.041)\end{array}$ & $\begin{array}{c}(0.080) \\
0.041 \\
(0.051)\end{array}$ \\
\hline $\begin{array}{l}\text { 3rd hh. inc. } \\
\text { Quartile }\end{array}$ & $\begin{array}{c}0.136 * * * \\
(0.051)\end{array}$ & $\begin{array}{c}0.196 * * * \\
(0.052)\end{array}$ & $\begin{array}{c}0.195^{* * *} \\
(0.050)\end{array}$ & $\begin{array}{l}0.088^{* *} \\
(0.041)\end{array}$ & $\begin{array}{c}0.211^{* * *} \\
(0.051)\end{array}$ & $\begin{array}{c}-0.036 \\
(0.037)\end{array}$ & $\begin{array}{c}0.015 \\
(0.046)\end{array}$ & $\begin{array}{c}0.066 * \\
(0.035)\end{array}$ & $\begin{array}{c}0.229 * * * \\
(0.041)\end{array}$ & $\begin{array}{c}0.204 * * * \\
(0.051)\end{array}$ & $\begin{array}{c}0.044 \\
(0.063)\end{array}$ & $\begin{array}{c}0.183^{* * *} * \\
(0.025)\end{array}$ & $\begin{array}{c}0.075^{*} \\
(0.044)\end{array}$ & $\begin{array}{l}0.119 * * \\
(0.054)\end{array}$ \\
\hline $\begin{array}{l}\text { 4th hh. inc. } \\
\text { quartile } \\
1991\end{array}$ & $\begin{array}{c}0.256 * * * \\
(0.052) \\
0.379 * * * \\
(0.057)\end{array}$ & $\begin{array}{c}0.372 * * * \\
(0.054) \\
0.273 * * * \\
(0.071)\end{array}$ & $\begin{array}{c}0.385 * * * \\
(0.053) \\
0.190 * * * \\
(0.061)\end{array}$ & $\begin{array}{c}0.207 * * * \\
(0.045) \\
0.293^{* * *} \\
(0.054)\end{array}$ & $\begin{array}{c}0.297^{* * *} * \\
(0.054) \\
0.128 * * \\
(0.054)\end{array}$ & $\begin{array}{c}0.121^{* * *} \\
(0.036)\end{array}$ & $\begin{array}{l}0.110 * * \\
(0.044)\end{array}$ & $\begin{array}{c}0.239 * * * \\
(0.037)\end{array}$ & $\begin{array}{c}0.387 * * * \\
(0.044) \\
0.892 * * * \\
(0.045)\end{array}$ & $\begin{array}{c}0.246 * * * \\
(0.057) \\
0.794 * * * \\
(0.051)\end{array}$ & $\begin{array}{c}0.077 \\
(0.065)\end{array}$ & $\begin{array}{c}0.346^{* * *} \\
(0.026)\end{array}$ & $\begin{array}{c}0.123^{* * *} \\
(0.044)\end{array}$ & $\begin{array}{c}0.137 * * \\
(0.058)\end{array}$ \\
\hline 1992 & $\begin{array}{c}0.176^{* * *} \\
(0.047)\end{array}$ & $\begin{array}{c}0.299 * * * \\
(0.056)\end{array}$ & $\begin{array}{c}-0.353 * * * \\
(0.064)\end{array}$ & $\begin{array}{c}0.236 * * * \\
(0.054)\end{array}$ & & & & & & $\begin{array}{c}0.495^{* * *} \\
(0.050)\end{array}$ & $\begin{array}{c}0.055 \\
(0.053)\end{array}$ & $\begin{array}{c}-0.255^{* * *} \\
(0.035)\end{array}$ & $\begin{array}{c}-0.279 * * * \\
(0.052)\end{array}$ & \\
\hline 1993 & $\begin{array}{c}0.416 * * * \\
(0.049)\end{array}$ & $\begin{array}{c}0.188^{* * *} * \\
(0.058)\end{array}$ & $\begin{array}{c}0.031 \\
(0.058)\end{array}$ & $\begin{array}{c}0.477 * * * \\
(0.055)\end{array}$ & $\begin{array}{c}0.420 * * * \\
(0.054)\end{array}$ & $\begin{array}{c}-0.054 \\
(0.046)\end{array}$ & $\begin{array}{c}0.164 * * * \\
(0.050)\end{array}$ & $\begin{array}{c}-0.124 * * * \\
(0.043)\end{array}$ & $\begin{array}{c}0.461 * * * \\
(0.044)\end{array}$ & & & $\begin{array}{c}0.031 \\
(0.034)\end{array}$ & $\begin{array}{c}-0.426 * * * \\
(0.045)\end{array}$ & $\begin{array}{c}-0.756 * * * \\
(0.054)\end{array}$ \\
\hline 1995 & $\begin{array}{c}0.269 * * * \\
(0.050)\end{array}$ & $\begin{array}{c}0.276^{* * *} \\
(0.047)\end{array}$ & $\begin{array}{l}-0.090 \\
(0.057)\end{array}$ & $\begin{array}{c}0.835^{* * *} \\
(0.053)\end{array}$ & $\begin{array}{c}0.425^{* * *} \\
(0.056)\end{array}$ & $\begin{array}{c}0.159 * * * \\
(0.048) \\
0.063\end{array}$ & $\begin{array}{c}0.272 * * * \\
(0.054) \\
0.059\end{array}$ & $\begin{array}{c}-0.301 * * * \\
(0.048) \\
-0.280 * * *\end{array}$ & $\begin{array}{c}0.425^{* * *} * \\
(0.043)\end{array}$ & & & $\begin{array}{c}-0.216 * * * \\
(0.034) \\
-0.022\end{array}$ & $\begin{array}{c}-0.636 * * * \\
(0.044)\end{array}$ & $\begin{array}{c}-0.766 * * * \\
(0.054)\end{array}$ \\
\hline
\end{tabular}




\begin{tabular}{|c|c|c|c|c|c|c|c|c|c|c|c|c|c|c|}
\hline & & & & & & $(0.048)$ & $(0.055)$ & $(0.046)$ & & & & $(0.031)$ & & \\
\hline 1998 & & $\begin{array}{c}0.161 * * * \\
(0.050)\end{array}$ & & & $\begin{array}{c}-0.009 \\
(0.058)\end{array}$ & & & & $\begin{array}{c}0.475 * * * \\
(0.045)\end{array}$ & $\begin{array}{c}0.391 * * * \\
(0.050)\end{array}$ & & $\begin{array}{c}-0.141 * * * \\
(0.035)\end{array}$ & $\begin{array}{c}-1.099 * * * \\
(0.046)\end{array}$ & $\begin{array}{c}-0.311 * * * \\
(0.053)\end{array}$ \\
\hline 2000 & & & & & & $\begin{array}{c}-0.153^{* * *} \\
(0.053)\end{array}$ & & $\begin{array}{c}-0.298 * * * \\
(0.044)\end{array}$ & & & & $\begin{array}{c}-0.161 * * * \\
(0.034)\end{array}$ & & \\
\hline 2001 & & & $\begin{array}{c}0.075 \\
(0.059)\end{array}$ & $\begin{array}{c}0.029 \\
(0.056)\end{array}$ & & $\begin{array}{l}-0.049 \\
(0.049)\end{array}$ & $\begin{array}{c}0.018 \\
(0.055)\end{array}$ & $\begin{array}{c}-0.239 * * * \\
(0.043)\end{array}$ & $\begin{array}{c}0.419 * * * \\
(0.040)\end{array}$ & & & $\begin{array}{c}0.008 \\
(0.033)\end{array}$ & & \\
\hline Minority & & & & & & $\begin{array}{c}-0.787 * * * \\
(0.028)\end{array}$ & $\begin{array}{c}-0.518 * * * \\
(0.033)\end{array}$ & $\begin{array}{c}-0.330 * * * \\
(0.027)\end{array}$ & & & & & & \\
\hline Constant & $\begin{array}{c}0.106 \\
(0.089)\end{array}$ & $\begin{array}{c}-0.454 * * * \\
(0.092)\end{array}$ & $\begin{array}{c}-0.444 * * * \\
(0.093)\end{array}$ & $\begin{array}{c}-0.188 * * \\
(0.080)\end{array}$ & $\begin{array}{l}-0.112 \\
(0.092)\end{array}$ & $\begin{array}{c}0.541 * * * \\
(0.071)\end{array}$ & $\begin{array}{l}-0.129 \\
(0.085)\end{array}$ & $\begin{array}{c}-0.136 * \\
(0.072)\end{array}$ & $\begin{array}{c}-0.496 * * * \\
(0.073)\end{array}$ & $\begin{array}{c}-0.195 * * \\
(0.084)\end{array}$ & $\begin{array}{c}0.333 * * * \\
(0.092)\end{array}$ & $\begin{array}{c}-0.645^{* * *} \\
(0.050)\end{array}$ & $\begin{array}{c}0.135 * \\
(0.079)\end{array}$ & $\begin{array}{c}0.152 \\
(0.102)\end{array}$ \\
\hline Observations & 4398 & 3771 & 4025 & 4612 & 3574 & 5313 & 3914 & 6040 & 5941 & 3708 & 1971 & 14632 & 4512 & 3387 \\
\hline R-squared & 0.07 & 0.08 & 0.10 & 0.12 & 0.08 & 0.22 & 0.11 & 0.12 & 0.17 & 0.10 & 0.02 & 0.08 & 0.19 & 0.12 \\
\hline
\end{tabular}
definitions are as in Table 4. 
Table 12: The role of individual preferences in explaining the lower support in CIS

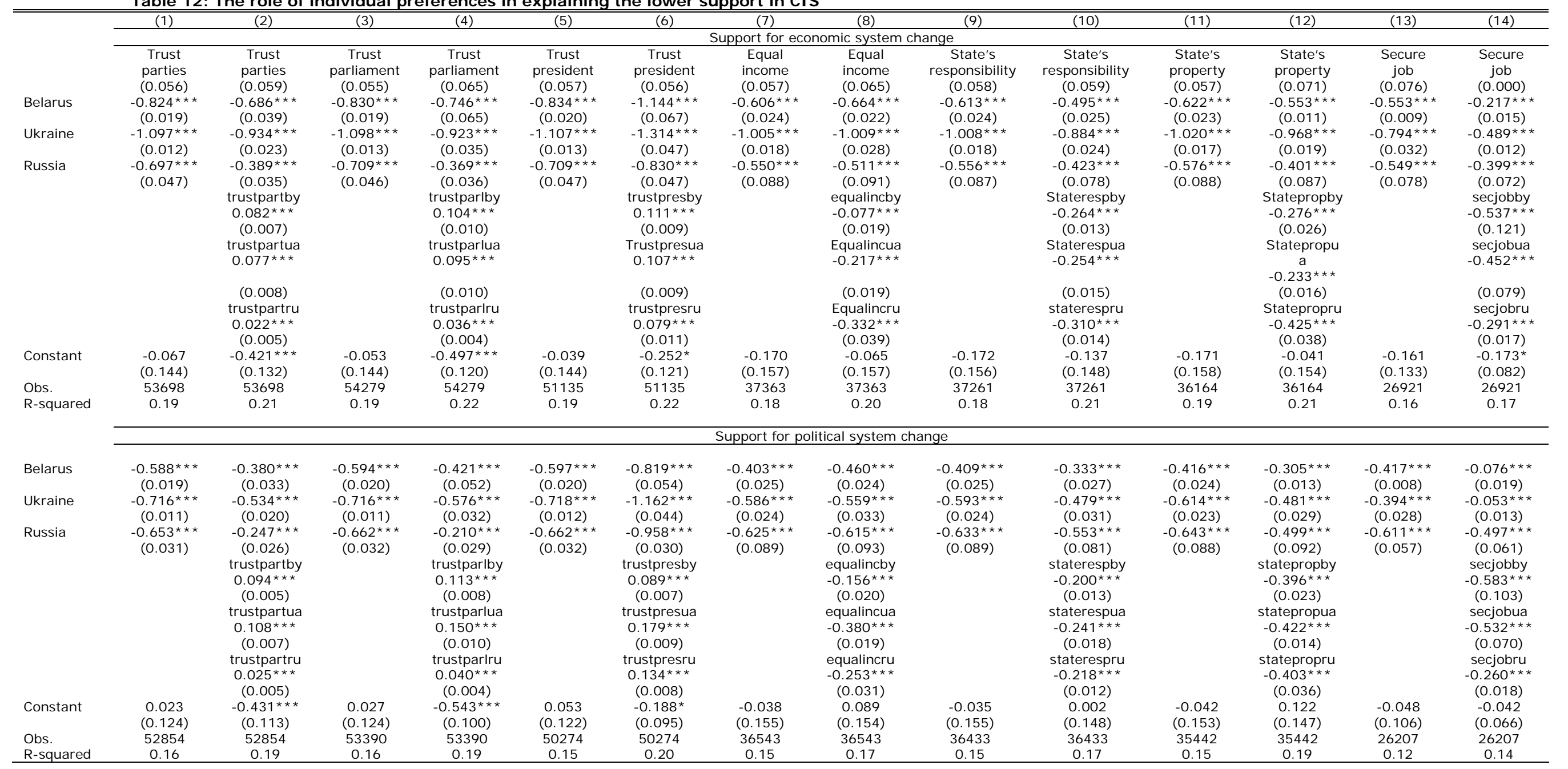

Notes: Estimation method: OLS. Standard errors clustered by country are in parentheses. * significant at 10 percent; $* *$ significant at 5 percent; $* * *$ significant at 1 percent. Additional controls include individual characteristics as in Table 3, country fixed effects, year dummies and interactions of country dummies and additional

individual variables. 
Table 13: The role of macroeconomic and institutional determinants in explaining the lower support in CIS: Economic system

\begin{tabular}{|c|c|c|c|c|c|c|c|}
\hline & (1) & (2) & (3) & (4) & (5) & (6) & (7) \\
\hline Czech Republic & $\begin{array}{c}0.520 * * * \\
(0.014)\end{array}$ & $\begin{array}{c}0.407 * * * \\
(0.038)\end{array}$ & $\begin{array}{c}0.344 * * * \\
(0.043)\end{array}$ & $\begin{array}{c}0.202 * * * \\
(0.054)\end{array}$ & $\begin{array}{c}0.415 * * * \\
(0.081)\end{array}$ & $\begin{array}{c}0.527 * * * \\
(0.108)\end{array}$ & $\begin{array}{c}0.532 * * * \\
(0.135)\end{array}$ \\
\hline Slovakia & $\begin{array}{c}-0.255^{* * *} \\
(0.012)\end{array}$ & $\begin{array}{l}-0.377^{*} \\
(0.186)\end{array}$ & $\begin{array}{c}-0.391^{* *} \\
(0.174)\end{array}$ & $\begin{array}{c}-0.647 * * \\
(0.216)\end{array}$ & $\begin{array}{l}-0.655 \\
(0.396)\end{array}$ & $\begin{array}{l}-0.385 \\
(0.506)\end{array}$ & $\begin{array}{l}-0.176 \\
(0.365)\end{array}$ \\
\hline Hungary & $\begin{array}{c}-0.385^{* * *} * \\
(0.014)\end{array}$ & $\begin{array}{c}-0.385^{* * *} \\
(0.120)\end{array}$ & $\begin{array}{c}-0.466 * * * \\
(0.115)\end{array}$ & $\begin{array}{c}-0.617^{* * *} * \\
(0.145)\end{array}$ & $\begin{array}{c}-0.700^{* *} \\
(0.287)\end{array}$ & $\begin{array}{l}-0.589 \\
(0.333)\end{array}$ & $\begin{array}{c}-0.339 \\
(0.277)\end{array}$ \\
\hline Poland & $\begin{array}{c}0.119 * * * \\
(0.012)\end{array}$ & $\begin{array}{c}0.071 \\
(0.252)\end{array}$ & $\begin{array}{c}0.010 \\
(0.236)\end{array}$ & $\begin{array}{c}0.074 \\
(0.349)\end{array}$ & $\begin{array}{l}-0.135 \\
(0.456)\end{array}$ & $\begin{array}{c}0.052 \\
(0.540)\end{array}$ & $\begin{array}{c}0.604 \\
(0.440)\end{array}$ \\
\hline Estonia & $\begin{array}{l}-0.036 \\
(0.035)\end{array}$ & $\begin{array}{l}-0.344 \\
(0.296)\end{array}$ & $\begin{array}{l}-0.384 \\
(0.276)\end{array}$ & $\begin{array}{l}-0.446 \\
(0.484)\end{array}$ & $\begin{array}{l}-0.945 \\
(0.671)\end{array}$ & $\begin{array}{l}-0.773 \\
(0.767)\end{array}$ & $\begin{array}{l}-0.716 \\
(0.581)\end{array}$ \\
\hline Lithuania & $\begin{array}{c}-0.679 * * * \\
(0.034)\end{array}$ & $\begin{array}{c}-0.675 * * \\
(0.256)\end{array}$ & $\begin{array}{c}-0.635 * * \\
(0.237)\end{array}$ & $\begin{array}{l}-0.545 \\
(0.342)\end{array}$ & $\begin{array}{l}-1.017^{*} \\
(0.508)\end{array}$ & $\begin{array}{l}-0.805 \\
(0.611)\end{array}$ & $\begin{array}{l}-0.727 \\
(0.444)\end{array}$ \\
\hline Latvia & $\begin{array}{c}-0.532 * * * \\
(0.035)\end{array}$ & $\begin{array}{c}-0.703^{*} \\
(0.327)\end{array}$ & $\begin{array}{c}-0.690 * * \\
(0.303)\end{array}$ & $\begin{array}{l}-0.792 \\
(0.467)\end{array}$ & $\begin{array}{l}-1.303^{*} \\
(0.692)\end{array}$ & $\begin{array}{l}-0.943 \\
(0.845)\end{array}$ & $\begin{array}{l}-0.819 \\
(0.664)\end{array}$ \\
\hline Bulgaria & $\begin{array}{c}-0.367 * * * \\
(0.009)\end{array}$ & $\begin{array}{l}-0.465 \\
(0.348)\end{array}$ & $\begin{array}{l}-0.395 \\
(0.320)\end{array}$ & $\begin{array}{c}-0.714 \\
(0.508)\end{array}$ & $\begin{array}{l}-1.271 \\
(0.773)\end{array}$ & $\begin{array}{l}-0.653 \\
(1.017)\end{array}$ & $\begin{array}{c}0.273 \\
(0.704)\end{array}$ \\
\hline Romania & $\begin{array}{c}-0.101 * * * \\
(0.031)\end{array}$ & $\begin{array}{l}-0.424 \\
(0.364)\end{array}$ & $\begin{array}{l}-0.369 \\
(0.327)\end{array}$ & $\begin{array}{l}-1.065^{*} \\
(0.558)\end{array}$ & $\begin{array}{l}-1.484 \\
(0.907)\end{array}$ & $\begin{array}{c}-0.684 \\
(1.173)\end{array}$ & $\begin{array}{c}0.670 \\
(0.819)\end{array}$ \\
\hline Croatia & $\begin{array}{c}0.218^{* * *} * \\
(0.036)\end{array}$ & $\begin{array}{l}-0.485 \\
(0.428)\end{array}$ & $\begin{array}{l}-0.475 \\
(0.402)\end{array}$ & & & & \\
\hline Russia & $\begin{array}{c}-0.689 * * * \\
(0.027)\end{array}$ & $\begin{array}{c}-1.094 * * * \\
(0.356)\end{array}$ & $\begin{array}{c}-1.033^{* * *} \\
(0.328)\end{array}$ & $\begin{array}{l}-1.380 * \\
(0.667)\end{array}$ & $\begin{array}{c}-2.129 * * \\
(0.922)\end{array}$ & $\begin{array}{l}-0.902 \\
(1.361)\end{array}$ & $\begin{array}{l}1.629 * \\
(0.911)\end{array}$ \\
\hline Ukraine & $\begin{array}{c}-1.054 * * * \\
(0.018)\end{array}$ & $\begin{array}{c}-1.424 * * * \\
(0.452)\end{array}$ & $\begin{array}{c}-1.301 * * * \\
(0.414)\end{array}$ & $\begin{array}{c}-2.064 * * \\
(0.727)\end{array}$ & $\begin{array}{c}-2.599 * * \\
(1.141)\end{array}$ & $\begin{array}{l}-1.372 \\
(1.569)\end{array}$ & $\begin{array}{c}0.578 \\
(1.090)\end{array}$ \\
\hline Belarus & $\begin{array}{c}-0.753 * * * \\
(0.022)\end{array}$ & $\begin{array}{c}-1.532 * * \\
(0.510)\end{array}$ & $\begin{array}{c}-1.361^{* *} \\
(0.473)\end{array}$ & $\begin{array}{c}-3.197 * * * \\
(0.875)\end{array}$ & $\begin{array}{l}-3.138^{*} \\
(1.559)\end{array}$ & $\begin{array}{l}-1.410 \\
(2.108)\end{array}$ & $\begin{array}{c}1.041 \\
(1.543)\end{array}$ \\
\hline $\begin{array}{l}\text { Unemployment } \\
\text { rate }\end{array}$ & & $\begin{array}{l}-0.013 \\
(0.007)\end{array}$ & $\begin{array}{c}-0.017 * * * \\
(0.006)\end{array}$ & $\begin{array}{c}-0.044 * * * \\
(0.014)\end{array}$ & $\begin{array}{l}-0.047 \\
(0.030)\end{array}$ & $\begin{array}{l}-0.034 \\
(0.026)\end{array}$ & $\begin{array}{l}-0.005 \\
(0.017)\end{array}$ \\
\hline GDP per capita & & $\begin{array}{l}-0.002 \\
(0.039)\end{array}$ & $\begin{array}{l}-0.004 \\
(0.034)\end{array}$ & $\begin{array}{l}-0.078 \\
(0.051)\end{array}$ & $\begin{array}{l}-0.109 \\
(0.083)\end{array}$ & $\begin{array}{l}-0.103 \\
(0.093)\end{array}$ & $\begin{array}{l}-0.101 \\
(0.070)\end{array}$ \\
\hline Inflation & & $\begin{array}{l}-0.000 \\
(0.000)\end{array}$ & $\begin{array}{l}-0.000 \\
(0.000)\end{array}$ & $\begin{array}{c}0.000 \\
(0.000)\end{array}$ & $\begin{array}{l}-0.001 \\
(0.000)\end{array}$ & $\begin{array}{l}-0.001 \\
(0.001)\end{array}$ & $\begin{array}{c}-0.002 * * * \\
(0.001)\end{array}$ \\
\hline Democracy & & $\begin{array}{c}-0.092 * * * \\
(0.019)\end{array}$ & $\begin{array}{c}-0.096 * * * \\
(0.020)\end{array}$ & $\begin{array}{c}-0.150 * * * \\
(0.048)\end{array}$ & $\begin{array}{l}-0.135 \\
(0.076)\end{array}$ & $\begin{array}{l}-0.107 \\
(0.085)\end{array}$ & $\begin{array}{l}-0.063 \\
(0.074)\end{array}$ \\
\hline $\begin{array}{l}\text { EBRD Transition } \\
\text { Index (lagged) }\end{array}$ & & & $\begin{array}{l}0.184^{*} \\
(0.098)\end{array}$ & & & & \\
\hline Gini index & & & & $\begin{array}{c}-3.780 * * * \\
(0.996)\end{array}$ & & & \\
\hline $\begin{array}{l}\text { Governance } \\
\text { Indicators }\end{array}$ & & & & & & $\begin{array}{c}0.640 \\
(0.394)\end{array}$ & \\
\hline $\begin{array}{l}\text { Voice and } \\
\text { accountability } \\
\text { Political stability }\end{array}$ & & & & & & & $\begin{array}{c}-0.725 * * * \\
(0.174) \\
1.159 * * * \\
(0.234)\end{array}$ \\
\hline
\end{tabular}


Government

effectiveness

Regulatory

quality

Rule of law

Control of

corruption

Constant

Observations

R-squared

Notes: Estimation method: OLS. Standard errors clustered by

percent. For

dummies
$-0.082$

(0.254)

$0.604 * * *$

(0.180)

1.153**

(0.441)

0.216

$(0.270)$

0.567

(1.948)

40420 
Table 14: The role of macroeconomic and institutional determinants in explaining the lower support in CIS: Political system

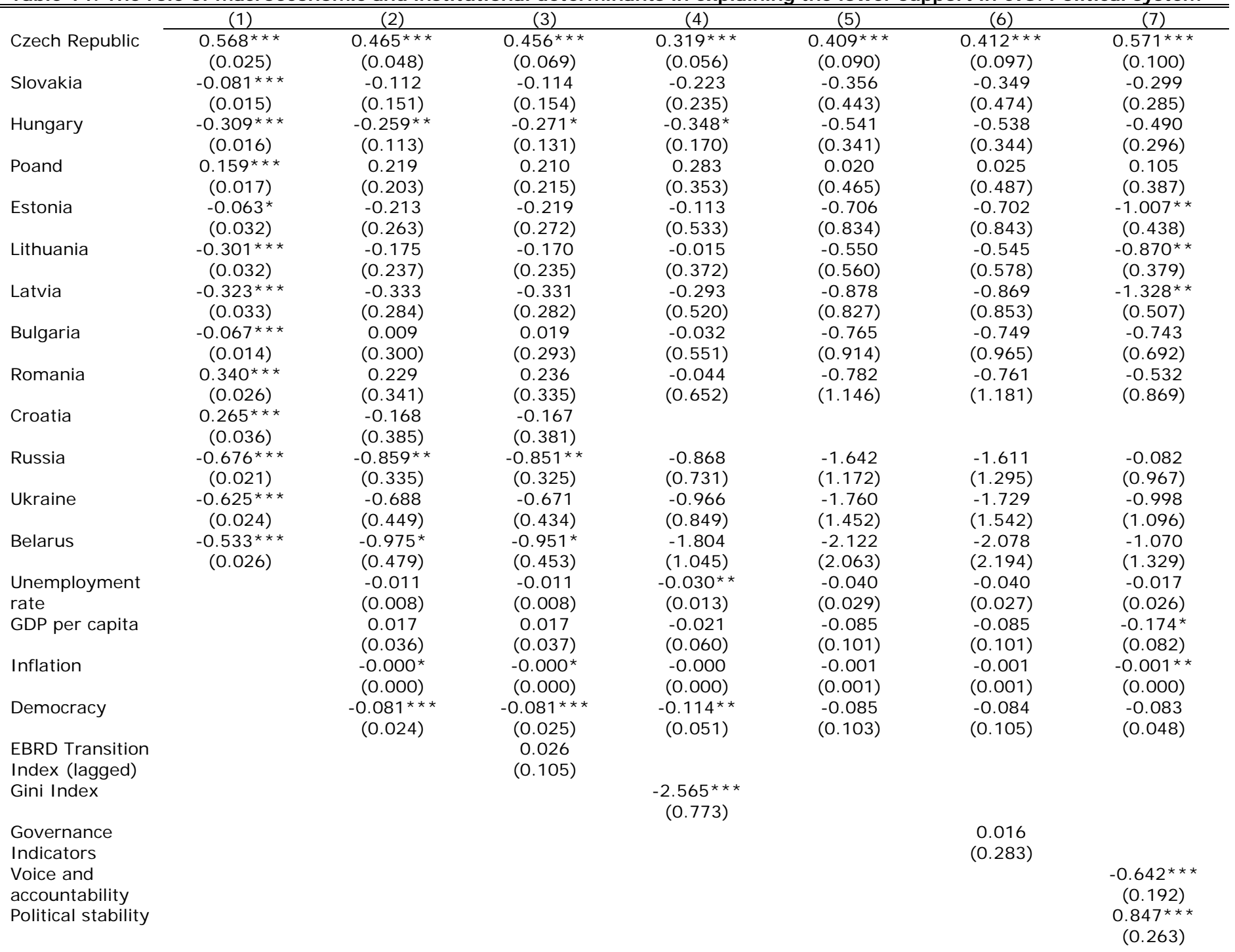


Government

effectiveness

Regulatory

quality

Rule of law

Control of

corruption

Constant

Observations

R-squared

$\begin{array}{ccc}0.016 & 0.627 & 0.552 \\ (0.123) & (0.840) & (0.785) \\ 70532 & 70532 & 70532 \\ 0.17 & 0.17 & 0.17\end{array}$

$0.17 \quad 0532$

\begin{tabular}{|c|c|c|c|c|}
\hline & & & & $\begin{array}{c}-0.217 \\
(0.258) \\
0.173 \\
(0.206) \\
1.586^{* * *} \\
(0.414) \\
-0.521^{*} \\
(0.263)\end{array}$ \\
\hline $\begin{array}{c}0.552 \\
(0.785)\end{array}$ & $\begin{array}{c}2.364 \\
(1.454)\end{array}$ & $\begin{array}{c}2.672 \\
(2.833)\end{array}$ & $\begin{array}{c}2.642 \\
(2.870)\end{array}$ & $\begin{array}{c}2.558 \\
(1.966)\end{array}$ \\
\hline 70532 & 48165 & 39666 & 39666 & 39666 \\
\hline 0.17 & 0.18 & 0.16 & 0.16 & 0.17 \\
\hline
\end{tabular}

Estimation method: OLS. Standard errors clustered by country are in parentheses. * significant at 10 percent; ** significant at 5 percent; *** significant at 1

percent. For definitions of macro and institutional variables, see text and Data Appendix. Additional controls include individual characteristics as in Table 4 and year dummies. 


\section{Data Appendix}

\section{a. Data acknowledgements and copyright}

This research was based on the New Europe Barometer (waves I-VII), New Russia Barometer (waves I-XIII) and New Baltic Barometer (waves I-VI) data produced by the Centre for the Study of Public Policy, University of Aberdeen/University of Strathclyde (prof. Richard Rose; and prof. W. Mishler, University of Arizona, for the NEB VII), sponsored by the Austrian Federal Ministry of Science and Research, Austrian National Bank and Paul Lazarsfeld Society (Vienna), as well as by the Centre for the Study of Public Policy, Bank of Sweden, Tercentenary Foundation, Economic and Social Research Council, MacArthur Foundation (Chicago), and supplied by the UK Data Archive. The data are Crown copyright. The original data creators, depositors or copyright holders, the funders of the Data Collections and the UK Data Archive bear no responsibility for the further analysis or interpretation of these data.

The following data were obtained directly from the UK Data Archive:

Rose, R., New Europe Barometer I-V, 1991-1998 [computer file]. Colchester, Essex: UK Data Archive [distributor], October 2005. SN: 5241.

Rose, R., New Europe Barometer VI, 2001 [computer file]. Colchester, Essex: UK Data Archive [distributor], October 2005. SN: 5242.

Rose, R. and Mishler, W., New Europe Barometer VII, 2004-2005 [computer file]. Colchester, Essex: UK Data Archive [distributor], July 2007. SN: 5243.

Rose, R., New Russia Barometer, 2000-2001 [computer file]. Colchester, Essex: UK Data Archive [distributor], November 2003. SN: 4550.

Rose, R., New Russia Barometer XIII, 2004 [computer file]. Colchester, Essex: UK Data Archive [distributor], August 2007. SN: 5700. 


\section{b. Tables and Figures}

Table A1: Evaluations of the economic and political systems: country/ year averages

\begin{tabular}{|c|c|c|c|c|c|c|}
\hline & Past & Present & $\begin{array}{c}\text { Distance = } \\
\text { Present-Past }\end{array}$ & Past & Present & $\begin{array}{c}\text { Distance = } \\
\text { Present-Past }\end{array}$ \\
\hline \multicolumn{6}{|l|}{ Czech R. } & 68.06 \\
\hline 2004 & -7.04 & 12.64 & 19.68 & -29.01 & 17.20 & 46.21 \\
\hline \multicolumn{7}{|l|}{ Slovakia } \\
\hline 1991 & 15.38 & -14.09 & -29.47 & -5.13 & 4.90 & 10.04 \\
\hline 2004 & 26.83 & -6.54 & -33.37 & 6.52 & -0.90 & -7.43 \\
\hline \multicolumn{7}{|l|}{ Hungary } \\
\hline 1991 & 21.03 & -11.99 & -33.01 & 3.81 & 7.50 & 3.69 \\
\hline 2004 & 30.99 & -4.15 & -35.14 & 15.57 & 8.76 & -6.81 \\
\hline \multicolumn{7}{|l|}{ Poland } \\
\hline 1991 & -6.35 & -20.02 & -13.67 & -21.00 & 0.23 & 21.23 \\
\hline 2004 & 22.28 & -2.29 & -24.57 & 0.30 & 1.27 & 0.97 \\
\hline \multicolumn{7}{|l|}{ Slovenia } \\
\hline 1991 & -6.12 & -32.21 & -26.08 & -6.74 & 3.50 & 10.25 \\
\hline 2004 & 32.43 & 11.66 & -20.76 & 22.48 & 19.69 & -2.78 \\
\hline \multicolumn{7}{|l|}{ Estonia } \\
\hline 1993 & 25.27 & -6.38 & -31.65 & 3.73 & 6.10 & 2.38 \\
\hline 2004 & 30.53 & 30.08 & -0.44 & 13.23 & 23.07 & 9.85 \\
\hline \multicolumn{7}{|l|}{ Latvia } \\
\hline 1993 & 23.79 & -26.16 & -49.95 & 1.55 & -4.28 & -5.83 \\
\hline 2004 & 30.23 & -1.03 & -31.26 & 6.93 & 0.86 & -6.06 \\
\hline \multicolumn{7}{|l|}{ Lithuania } \\
\hline 1993 & 40.61 & -26.71 & -67.32 & 10.30 & 0.57 & -9.73 \\
\hline 2004 & 38.58 & 20.97 & -17.61 & 16.45 & 20.91 & 4.45 \\
\hline \multicolumn{7}{|l|}{ Bulgaria } \\
\hline 1991 & 0.12 & -23.44 & -23.56 & -23.97 & 26.73 & 50.70 \\
\hline 2004 & 42.25 & -12.99 & -55.24 & 29.90 & -0.40 & -30.30 \\
\hline \multicolumn{7}{|l|}{ Romania } \\
\hline 1991 & -3.49 & -14.12 & -10.63 & -37.16 & 21.78 & 58.94 \\
\hline 2004 & 24.76 & -4.12 & -28.88 & -1.51 & 3.52 & 5.03 \\
\hline \multicolumn{7}{|l|}{ Croatia } \\
\hline 1992 & -19.02 & -25.35 & -6.32 & -41.85 & -10.31 & 31.55 \\
\hline 1998 & 5.42 & -26.87 & -32.29 & -10.32 & -21.55 & -11.23 \\
\hline \multicolumn{7}{|l|}{ Russia } \\
\hline 1992 & 15.61 & -50.95 & -66.57 & 4.29 & -42.15 & -46.44 \\
\hline 2004 & 41.02 & -3.32 & -44.35 & 30.59 & 5.35 & -25.24 \\
\hline \multicolumn{7}{|l|}{ Ukraine } \\
\hline 1992 & 29.61 & -60.46 & -90.06 & 6.09 & -18.43 & -24.51 \\
\hline 2004 & 40.44 & 1.25 & -39.18 & 20.10 & 17.81 & -2.29 \\
\hline \multicolumn{7}{|l|}{ Belarus } \\
\hline 1991 & 45.08 & -37.59 & -82.67 & 23.85 & -25.56 & -49.41 \\
\hline 2004 & 34.56 & 24.33 & -10.23 & 17.05 & 22.46 & 5.41 \\
\hline
\end{tabular}

Summary

\begin{tabular}{|c|c|c|c|c|c|}
\hline \multirow{2}{*}{\multicolumn{2}{|c|}{$\begin{array}{l}\text { No. of countries } \\
\text { with average } \\
\text { response: }\end{array}$}} & \multicolumn{2}{|c|}{ Economic system } & \multicolumn{2}{|c|}{ Political system } \\
\hline & & Past & Present & Past & Present \\
\hline Negative & $1001 / 2$ & 5 & 13 & 7 & 5 \\
\hline Positive & $1 / 3$ & 9 & 1 & 7 & 9 \\
\hline Negative & 2004 & 1 & 8 & 3 & 3 \\
\hline Positive & 2004 & 13 & 6 & 11 & 11 \\
\hline
\end{tabular}

Notes: Source of data: New Barometer Surveys. Definition of variables: see text and Table A3. 
Table A2: Sample size by country

\begin{tabular}{|c|c|c|c|c|c|c|c|c|c|c|}
\hline & 1991 & 1992 & 1993 & 1995 & 1996 & 1998 & 2000 & 2001 & 2004 & Total \\
\hline Bulgaria & 892 & 0 & 1035 & 1043 & 0 & 766 & 0 & 1086 & 1130 & 5952 \\
\hline Czech Republic & 611 & 1187 & 998 & 822 & 0 & 0 & 0 & 0 & 768 & 4386 \\
\hline Slovakia & 264 & 522 & 458 & 932 & 0 & 777 & 0 & 0 & 848 & 3801 \\
\hline Hungary & 756 & 594 & 818 & 876 & 0 & 0 & 0 & 650 & 474 & 4168 \\
\hline Poland & 941 & 962 & 763 & 819 & 0 & 0 & 0 & 629 & 590 & 4704 \\
\hline Romania & 949 & 956 & 0 & 0 & 0 & 1043 & 0 & 0 & 792 & 3740 \\
\hline Croatia & 0 & 982 & 989 & 0 & 0 & 0 & 0 & 0 & 0 & 1971 \\
\hline Slovenia & 835 & 0 & 810 & 631 & 0 & 610 & 0 & 0 & 753 & 3639 \\
\hline Belarus & 0 & 0 & 874 & 888 & 0 & 959 & 0 & 0 & 713 & 3434 \\
\hline Ukraine & 0 & 624 & 816 & 834 & 0 & 801 & 0 & 0 & 1578 & 4653 \\
\hline Russia & 0 & 1974 & 1741 & 1765 & 2310 & 1544 & 1686 & 1821 & 1820 & 14661 \\
\hline Estonia & 0 & 0 & 1474 & 1053 & 839 & 0 & 593 & 826 & 721 & 5506 \\
\hline Latvia & 0 & 0 & 1346 & 855 & 729 & 0 & 648 & 732 & 769 & 5079 \\
\hline Lithuania & 0 & 0 & 1688 & 766 & 855 & 0 & 960 & 1059 & 990 & 6318 \\
\hline Total & 5248 & 7801 & 13810 & 11284 & 4733 & 6500 & 3887 & 6803 & 11946 & 72012 \\
\hline
\end{tabular}

Source: Authors' tabulations form the New Barometer data.

Notes: finals sample includes respondents with non-missing information on the key explanatory variables (as well as support for economic reforms).

Table A3: Variables definitions and sources

\begin{tabular}{|c|c|}
\hline Variable & Description and sources \\
\hline \multicolumn{2}{|l|}{ Dependent variables: } \\
\hline $\begin{array}{l}\text { distec } \\
\text { distpol }\end{array}$ & $\begin{array}{l}\text { Distance between present and past. Constructed as a difference between the } \\
\text { individual ranking of the functioning of the present economy (political system) } \\
\text { and past social economy (political system). It ranges from }-200 \text { and }+200 \text { and is } \\
\text { treated as continuous. }\end{array}$ \\
\hline $\begin{array}{l}\text { Positive, negative, } \\
\text { nostalgic, pro-market. } \\
\text { Compliant, skeptic, }\end{array}$ & $\begin{array}{l}\text { Binary mutually exclusive variables defining whether individual belongs to a } \\
\text { specific group based on his evaluations of past and present economic (political) } \\
\text { systems. }\end{array}$ \\
\hline & $\begin{array}{l}\text { Source: New Europe Barometers New Russian Barometers New Baltic } \\
\text { Barometers. }\end{array}$ \\
\hline \multicolumn{2}{|l|}{$\begin{array}{l}\text { Independent individual } \\
\text { characteristics: }\end{array}$} \\
\hline Female & Dummy variable equals to 1 if female \\
\hline Age $<30$ & $\begin{array}{l}\text { Dummy indicating if individual's age is less than } 30 \text { years old (Reference } \\
\text { category) }\end{array}$ \\
\hline Age $30-39$ & $\begin{array}{l}\text { Dummy indicating if individual's age is greater than } 30 \text { and less than } 39 \text { years } \\
\text { old }\end{array}$ \\
\hline Age $40-49$ & $\begin{array}{l}\text { Dummy indicating if individual's age is greater than } 40 \text { and less than } 49 \text { years } \\
\text { old }\end{array}$ \\
\hline Age $50-59$ & $\begin{array}{l}\text { Dummy indicating if individual's age is greater than } 50 \text { and less than } 59 \text { years } \\
\text { old }\end{array}$ \\
\hline Age $>60$ & Dummy indicating if individual's age is greater than 60 years old \\
\hline Elementary education & Dummy indicating if an individual has elementary education (Reference category) \\
\hline $\begin{array}{l}\text { Secondary or vocational } \\
\text { education }\end{array}$ & Dummy indicating if an individual has secondary or vocational education \\
\hline University & Dummy indicating if an individual has university degree \\
\hline Married & Dummy indicating if an individual is married or cohabiting (Reference category) \\
\hline Single & Dummy indicating if an individual is single \\
\hline Divorced or widowed & Dummy indicating if an individual is divorced separated or widowed \\
\hline
\end{tabular}




\begin{tabular}{|c|c|}
\hline Small town or rural & $\begin{array}{l}\text { Dummy indicating if an individual resides in a small town or rural area (with } \\
\text { population less or equal to 5000; in Russia <20000) (Reference category) }\end{array}$ \\
\hline Big town & $\begin{array}{l}\text { Dummy indicating if an individual resides in a big town (with population greater } \\
\text { than } 5000 \text { and less than 100000; in Russia - between } 20000 \text { and 1000000) }\end{array}$ \\
\hline City & $\begin{array}{l}\text { Dummy indicating if an individual resides in a city including capital (with } \\
\text { population }>100000 \text {; in Russia }>1000000 \text { ) }\end{array}$ \\
\hline Employed & $\begin{array}{l}\text { Dummy indicating if an individual is employed (full-time part-time family helper } \\
\text { apprentice or self-employed including and working pensioners in some countries) }\end{array}$ \\
\hline Unemployed & $\begin{array}{l}\text { Dummy indicating if an individual is unemployed (including both with and without } \\
\text { benefits in Russia) }\end{array}$ \\
\hline Pensioner & Dummy indicating if an individual is a pensioner \\
\hline Student or housewife & $\begin{array}{l}\text { Dummy indicating if an individual is a house-keeper or a student since in several } \\
\text { countries it was not possible to disentangle these two categories. }\end{array}$ \\
\hline 1st hh. income quartile & $\begin{array}{l}\text { Dummy indicating if household is in the first quartile of the country-specific } \\
\text { income distribution (Reference category) }\end{array}$ \\
\hline $2^{\text {nd }} \mathrm{hh}$. income quartile & $\begin{array}{l}\text { Dummy indicating if household is in the second quartile of the country-specific } \\
\text { income distribution }\end{array}$ \\
\hline $3^{\text {rd }} \mathrm{hh}$. income quartile & $\begin{array}{l}\text { Dummy indicating if household is in the third quartile of the country-specific } \\
\text { income distribution }\end{array}$ \\
\hline $4^{\text {th }}$ hh. income quartile & $\begin{array}{l}\text { Dummy indicating if household is in the fourth quartile of the country-specific } \\
\text { income distribution }\end{array}$ \\
\hline Minority & $\begin{array}{l}\text { Dummy indicating if an individual belongs to an ethnic minority in a country (in } \\
\text { the Baltic States) }\end{array}$ \\
\hline $\begin{array}{l}\text { Number of weeks with } \\
\text { hardship }\end{array}$ & $\begin{array}{l}\text { Number of weeks during which a person was either unemployed or salary was } \\
\text { delayed or not paid in full last year }(1993,1995,1996,1998)\end{array}$ \\
\hline Doing without & $\begin{array}{l}\text { Destitution scale constructed by sociologists and political scientists indicates a } \\
\text { degree of hardship (increasing from } 0 \text { to } 9 \text { ) based on the information whether a } \\
\text { person or his family had to live without food heating electricity or clothes ( } 1993 \text { - } \\
2001 \text { ) }\end{array}$ \\
\hline Reforms right & $\begin{array}{l}\text { Dummy indicating whether an individual thinks that reforms in his country are } \\
\text { being conducted at the right speed (Reference category) }(1995,1996)\end{array}$ \\
\hline Reforms fast & $\begin{array}{l}\text { Dummy indicating whether an individual thinks that reforms in his country are } \\
\text { going too fast }(1995,1996)\end{array}$ \\
\hline Reforms slow & $\begin{array}{l}\text { Dummy indicating whether an individual thinks that reforms in his country are } \\
\text { going too slow }(1995,1996)\end{array}$ \\
\hline Parliament suspend & $\begin{array}{l}\text { Dummy indicating whether an individual would approve if the Parliament was } \\
\text { suspended (1991 - 2004) }\end{array}$ \\
\hline Leader & $\begin{array}{l}\text { Dummy that equals } 1 \text { if an individual agrees with the statement: it would be } \\
\text { better to get rid of Parliament and elections and have a strong leader (1992- } \\
2004 \text { ) }\end{array}$ \\
\hline Corruption & $\begin{array}{l}\text { Dummy that that equals } 1 \text { if an individual think that most or almost all "public } \\
\text { officials are engaged in bribe-taking and corruption" in his country and equals } \\
\text { zero if he thinks that "very few" or "less than half public officials are corrupt" } \\
(2001,2004) \text {. }\end{array}$ \\
\hline Equal income & $\begin{array}{l}\text { Dummy that equals } 1 \text { if an individual agrees with the statement that "incomes } \\
\text { should be made more equal so there is no big difference in income" as opposed } \\
\text { to the statement "Individual achievement should determine how much people are } \\
\text { paid" }(1992,1993,1995,1998,2004)\end{array}$ \\
\hline Return to Communism & $\begin{array}{l}\text { Dummy equals } 1 \text { if an individual agrees with the statement "We should return to } \\
\text { Communist rule" (1993-2004) }\end{array}$ \\
\hline
\end{tabular}




\begin{tabular}{|c|c|}
\hline Ex-Communist & $\begin{array}{l}\text { Dummy equals } 1 \text { if an individual or his family were members of the Communist } \\
\text { party }(1993,1995,1998)\end{array}$ \\
\hline Trust parties & $\begin{array}{l}\text { Variable indicating a degree of individual's trust in political parties (ranges from } 1 \\
\text { to 7) (1992-2004) }\end{array}$ \\
\hline Trust Parliament & $\begin{array}{l}\text { Variable indicating a degree of individual's trust in Parliament (ranges from } 1 \text { to } \\
\text { 7) (1992-2004) }\end{array}$ \\
\hline Trust President & $\begin{array}{l}\text { Variable indicating a degree of individual's trust in President (ranges from } 1 \text { to } 7 \text { ) } \\
\text { (1993-2004) }\end{array}$ \\
\hline Trust people & $\begin{array}{l}\text { Variable indicating a degree of individual's trust in people of his country (ranges } \\
\text { from } 1 \text { to 7) (1998-2004) } \\
\text { Source: New Europe Barometers New Russian Barometers New Baltic } \\
\text { Barometers. }\end{array}$ \\
\hline \multicolumn{2}{|l|}{$\frac{\text { Macroeconomic variables }}{\underline{\text { and political institutions: }}}$} \\
\hline Unemployment rate & $\begin{array}{l}\text { Unemployment rate (Source: EBRD. For Belarus the data are from IMF } \\
\text { International Financial Statistics CD Rom for Ukraine - from World Development } \\
\text { Indicators CD Rom for Estonia in } 1990 \text { and } 1991 \text { - from the World Development } \\
\text { Indicators online database) }\end{array}$ \\
\hline GDP per capita & $\begin{array}{l}\text { GDP per capita PPP (constant } 2000 \text { international \$) (Source: World Development } \\
\text { Indicators online database) }\end{array}$ \\
\hline Inflation & $\begin{array}{l}\text { Inflation GDP deflator (annual percent) (Source: World Development Indicators } \\
\text { online database) }\end{array}$ \\
\hline EBRD Transition Indicators & $\begin{array}{l}\text { Average of EBRD indicators of the progress in transition lagged one year } \\
\text { (Source: EBRD 2007) }\end{array}$ \\
\hline Hospital beds & $\begin{array}{l}\text { Hospital beds per } 1000 \text { of people in a country (Source: World Development } \\
\text { Indicators CD Rom) }\end{array}$ \\
\hline Gini Index & $\begin{array}{l}\text { Gini index (Source: Transmonee dataset. For Bulgaria Czech Republic Estonia } \\
\text { Latvia Lithuania Ukraine Croatia and Belarus } 1990 \text { is used instead of } 1991 \text {. In } \\
\text { Latvia } 1997 \text { is used instead of } 1995 \text { and } 2000 \text { instead of } 2001 \text {. For Lithuania } \\
1996 \text { is used instead of 1995. For Russia instead of } 1993 \text { use } 1994 \text {. For Slovakia } \\
\text { instead of } 1995 \text { use 1996. For Slovenia and Ukraine instead of } 2004 \text { use } 2002 .\end{array}$ \\
\hline Democracy & $\begin{array}{l}\text { Democracy Indicator which is an additive eleven-point scale (0-10) (Source: } \\
\text { Polity IV) }\end{array}$ \\
\hline Governance & $\begin{array}{l}\text { Average of the World Bank Governance Indicators (Source: } \\
\text { http://info.worldbank.org/governance/wgi/sc_chart.asp ). They include the } \\
\text { following six indicators: } \\
\text { Voice and Accountability / Political Stability / Government Effectiveness / } \\
\text { Regulatory Quality / Rule of Law / Control of Corruption. } \\
\text { Note: data from } 1996 \text { is used instead of 1995, and from } 2002 \text { instead of } 2001\end{array}$ \\
\hline
\end{tabular}


Table A4: Indicators of macroeconomic performance and institutional quality

\begin{tabular}{|c|c|c|c|c|c|c|c|c|c|}
\hline & $\begin{array}{l}\text { Transition } \\
\text { Indicators }\end{array}$ & $\begin{array}{l}\text { Unempl. } \\
\text { rate }\end{array}$ & $\begin{array}{l}\text { GDP per } \\
\text { capita }\end{array}$ & $\begin{array}{l}\text { Priv.sector } \\
\text { (percent of } \\
\text { GDP) }\end{array}$ & $\begin{array}{l}\text { Inflation } \\
\text { rate }\end{array}$ & $\begin{array}{l}\text { Gini } \\
\text { Index }\end{array}$ & $\begin{array}{l}\text { Democracy } \\
\text { Index }\end{array}$ & $\begin{array}{l}\text { Governance } \\
\text { Indicators }\end{array}$ & Life expect. \\
\hline \multicolumn{10}{|c|}{ Czech R. } \\
\hline 1991 & 2.11 & 4.10 & 13.27 & 15 & 36 & 0.19 & 8 & & 71.90 \\
\hline 1995 & 3.30 & 4.02 & 14.27 & 70 & 17 & 0.22 & 10 & 0.86 & 73.07 \\
\hline 1998 & 3.48 & 6.45 & 14.68 & 75 & 11 & 0.21 & 10 & 0.76 & 74.42 \\
\hline 2004 & 3.74 & 8.40 & 17.53 & 80 & 4 & 0.23 & 10 & 0.75 & 75.72 \\
\hline \multicolumn{10}{|c|}{ Slovakia } \\
\hline 1991 & 2.11 & 9.53 & 9.59 & 15 & 35 & & 8 & & 70.88 \\
\hline 1995 & 3.11 & 13.10 & 9.54 & 60 & 10 & 0.24 & 7 & 0.43 & 72.25 \\
\hline 1998 & 3.22 & 12.49 & 11.24 & 75 & 5 & 0.26 & 9 & 0.47 & 72.57 \\
\hline 2004 & 3.67 & 17.10 & 13.43 & 80 & 6 & 0.25 & 9 & 0.73 & 73.96 \\
\hline \multicolumn{10}{|c|}{ Hungary } \\
\hline 1991 & 2.37 & 8.22 & 10.42 & 30 & 36 & 0.21 & 10 & & 69.38 \\
\hline 1995 & 3.48 & 10.17 & 10.54 & 60 & 27 & 0.24 & 10 & 0.73 & 69.79 \\
\hline 1998 & 3.78 & 7.80 & 11.78 & 80 & 13 & 0.25 & 10 & 0.90 & 70.56 \\
\hline 2004 & 3.89 & 6.31 & 15.55 & 80 & 4 & 0.27 & 10 & 0.91 & 72.65 \\
\hline \multicolumn{10}{|l|}{ Poland } \\
\hline 1991 & 2.41 & 12.25 & 6.95 & 40 & 55 & 0.26 & 8 & & 70.59 \\
\hline 1995 & 3.22 & 14.94 & 8.25 & 60 & 41 & 0.32 & 9 & 0.66 & 71.89 \\
\hline 1998 & 3.52 & 11.00 & 9.84 & 65 & 11 & 0.33 & 9 & 0.72 & 73.00 \\
\hline 2004 & 3.66 & 18.20 & 12.17 & 75 & 4 & 0.37 & 10 & 0.51 & 74.49 \\
\hline \multicolumn{10}{|c|}{ Slovenia } \\
\hline 1991 & 1.89 & 7.30 & 12.71 & 20 & 95 & 0.26 & 10 & & 73.35 \\
\hline 1995 & 2.93 & 7.35 & 13.57 & 50 & 25 & 0.25 & 10 & 0.95 & 73.44 \\
\hline 1998 & 3.22 & 7.84 & 15.39 & 60 & 7 & 0.25 & 10 & 1.06 & 74.77 \\
\hline 2004 & 3.37 & 6.48 & 19.09 & 65 & 3 & 0.24 & 10 & 0.98 & 76.57 \\
\hline \multicolumn{10}{|l|}{ Estonia } \\
\hline 1993 & 2.70 & 6.56 & 6.39 & 40 & 85 & & 7 & & 67.96 \\
\hline 1995 & 3.15 & 9.71 & 6.83 & 65 & 31 & 0.40 & 7 & 0.66 & 67.85 \\
\hline 2001 & 3.70 & 12.58 & 10.15 & 75 & 5 & 0.38 & 7 & 0.96 & 70.51 \\
\hline 2004 & 3.81 & 9.65 & 12.83 & 80 & 2 & 0.38 & 7 & 1.04 & 71.57 \\
\hline \multicolumn{10}{|l|}{ Latvia } \\
\hline 1993 & 2.26 & 8.73 & 5.49 & 30 & 54 & & 8 & & 66.72 \\
\hline 1995 & 2.81 & 18.05 & 5.71 & 55 & 28 & 0.33 & 8 & 0.19 & 66.39 \\
\hline 2001 & 3.29 & 13.10 & 8.66 & 65 & 2 & 0.33 & 8 & 0.63 & 70.10 \\
\hline 2004 & 3.56 & 10.40 & 10.96 & 70 & 7 & 0.39 & 8 & 0.68 & 71.45 \\
\hline \multicolumn{10}{|c|}{ Lithuania } \\
\hline 1993 & 2.44 & 4.36 & 7.24 & 35 & 306 & & 10 & & 68.91 \\
\hline 1995 & 2.85 & 17.54 & 6.84 & 65 & 49 & 0.35 & 10 & 0.31 & 69.01 \\
\hline 2001 & 3.37 & 17.36 & 9.35 & 70 & 0 & 0.35 & 10 & 0.72 & 71.61 \\
\hline 2004 & 3.52 & 11.38 & 11.99 & 75 & 3 & 0.31 & 10 & 0.79 & 71.92 \\
\hline \multicolumn{10}{|c|}{ Bulgaria } \\
\hline 1991 & 1.70 & 10.52 & 6.17 & 20 & 227 & 0.23 & 8 & & 71.56 \\
\hline 1995 & 2.33 & 13.69 & 6.07 & 50 & 63 & 0.38 & 8 & -0.29 & 71.05 \\
\hline 1998 & 2.81 & 15.97 & 5.49 & 65 & 24 & 0.34 & 8 & 0.07 & 71.06 \\
\hline 2004 & 3.37 & 12.03 & 7.68 & 75 & 5 & 0.36 & 9 & 0.24 & 72.36 \\
\hline Romani & & & & & & & & & \\
\hline 1991 & 1.26 & 3.03 & 5.90 & 25 & 195 & 0.26 & 5 & & 69.78 \\
\hline 1995 & 2.41 & 9.52 & 6.22 & 45 & 35 & 0.31 & 5 & -0.13 & 69.46 \\
\hline 1998 & 2.89 & 6.32 & 5.83 & 60 & 55 & 0.30 & 8 & 0.00 & 69.30 \\
\hline 2004 & 3.22 & 6.30 & 7.73 & 70 & 15 & 0.36 & 9 & 0.01 & 71.31 \\
\hline Croatia & & & & & & & & & \\
\hline 1992 & 1.93 & 13.20 & 7.47 & . & 595 & . & 1 & & 71.24 \\
\hline 1995 & 2.70 & 14.50 & 7.43 & . & 5 & & 0 & -0.25 & 72.08 \\
\hline 1998 & 3.04 & 11.40 & 8.94 & . & 8 & 0.35 & 0 & -0.09 & 72.50 \\
\hline Russia & & & & & & & & & \\
\hline 1992 & 1.89 & 5.29 & 8.32 & 25 & 1490 & & 6 & & 66.87 \\
\hline 1995 & 2.59 & 9.20 & 6.39 & 55 & 144 & 0.44 & 5 & -0.67 & 65.22 \\
\hline 1998 & 2.55 & 11.90 & 5.96 & 70 & 19 & 0.45 & 5 & -0.67 & 66.78 \\
\hline 2004 & 2.96 & 7.60 & 9.02 & 70 & 20 & . & 7 & -0.63 & 65.21 \\
\hline Ukraine & & & & & & & & & \\
\hline 1992 & 1.19 & 0.40 & 7.25 & 10 & 1761 & & 6 & & 68.88 \\
\hline 1995 & 2.19 & 5.60 & 4.26 & 45 & 416 & 0.47 & 7 & -0.52 & 67.12 \\
\hline 1998 & 2.48 & 11.30 & 3.75 & 55 & 12 & 0.31 & 7 & -0.70 & 67.97 \\
\hline 2004 & 2.81 & 8.60 & 5.89 & 65 & 15 & 0.33 & 6 & -0.62 & 68.19 \\
\hline Belarus & & & & & & & & & \\
\hline 1992 & 1.26 & 0.50 & 4.74 & . & 1074 & & 7 & & 70.02 \\
\hline 1995 & 2.00 & 2.50 & 3.47 & . & 661 & 0.25 & 3 & -1.09 & 68.46 \\
\hline 1998 & 1.52 & 2.40 & 4.36 & . & 77 & 0.25 & 0 & -0.82 & 68.41 \\
\hline 2004 & 1.81 & 2.50 & 6.42 & & 23 & 0.25 & 0 & -1.08 & 68.39 \\
\hline
\end{tabular}

Notes: See Table A3 for definitions and sources. 
Figure A1: GDP per capita and support for change in the economic system
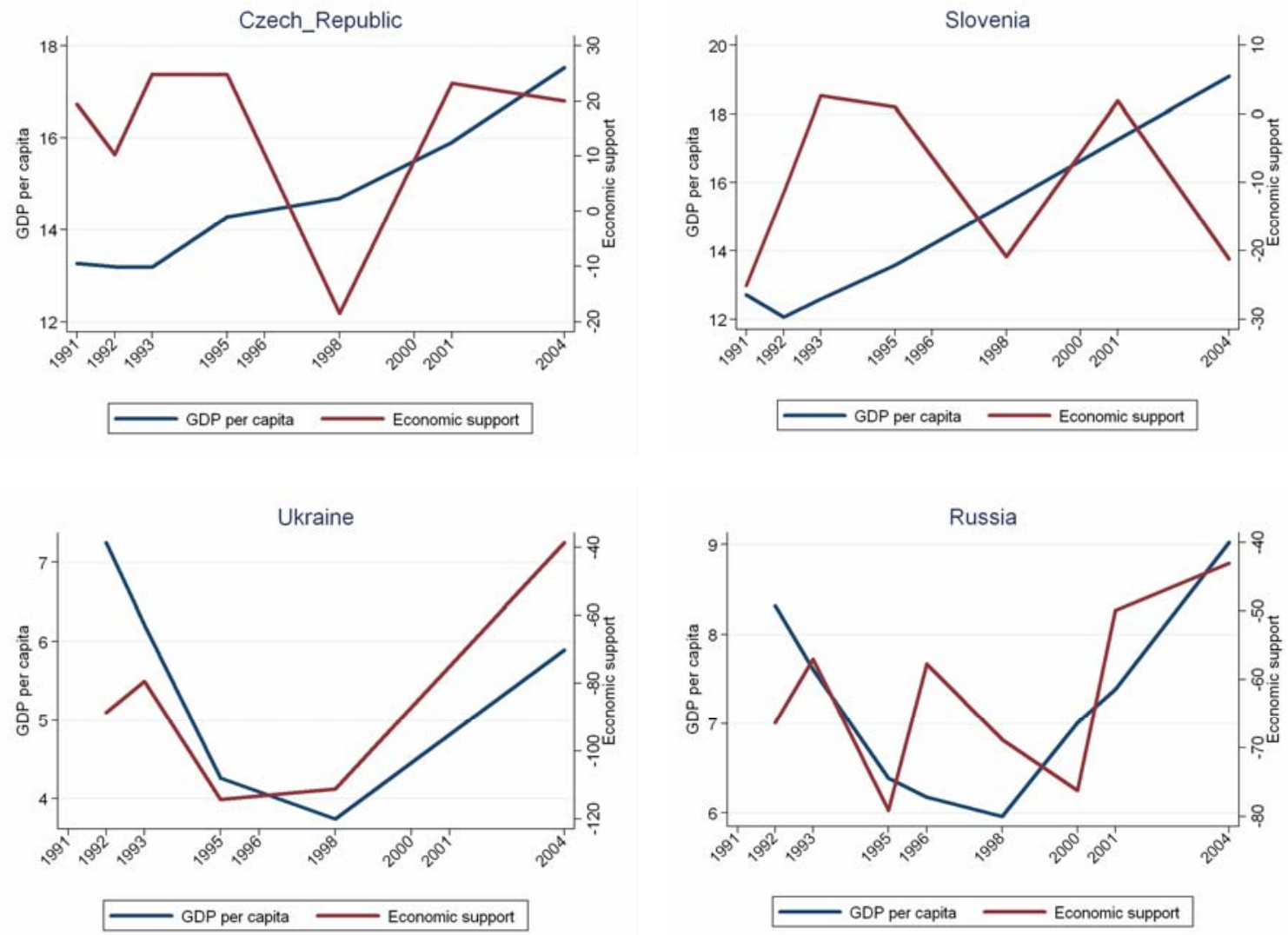

Source: authors' tabulations based on the data from the New Barometers and World Development Indicators. 